Pace University

DigitalCommons@Pace

$1-1-2005$

\title{
The Profits and Penalties of Kinship: Conflicting Meanings of Family in Estate Tax Law
}

Bridget J. Crawford

Elisabeth Haub School of Law at Pace University

Follow this and additional works at: https://digitalcommons.pace.edu/lawfaculty

Part of the Family Law Commons, and the Taxation-Federal Estate and Gift Commons

\section{Recommended Citation}

Bridget J. Crawford, The Profits and Penalties of Kinship: Conflicting Meanings of Family in Estate Tax Law, 3 Pittsburgh Tax Rev.1 (2005), http://digitalcommons.pace.edu/lawfaculty/242/.

This Article is brought to you for free and open access by the School of Law at DigitalCommons@Pace. It has been accepted for inclusion in Pace Law Faculty Publications by an authorized administrator of DigitalCommons@Pace. For more information, please contact dheller2@law.pace.edu. 


\title{
THE PROFITS AND PENALTIES OF KINSHIP: CONFLICTING MEANINGS OF FAMILY IN ESTATE TAX LAW
}

\author{
Bridget J. Crawford"
}

Table of Contents

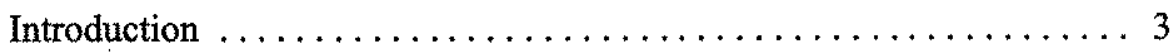

I. Family Conflict: Varied Definitions of "Family" in Estate Tax

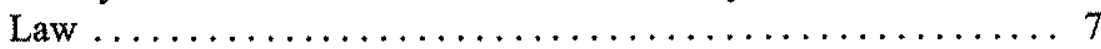

A. The Scope of the Gross Estate ................. 7

1. I.R.C. $\$ 2036(a)(1)$ and I.R.C. $\$ 2036(b)(2)$ : Transfers With a Retained Interest . ................. 7

2. I.R.C. $\$ 2036(\mathrm{a})(2)$ : Transfers With a Retained Right to Designate Possession or Enjoyment of Property ..... 12

B. Valuing the Gross Estate-I.R.C. $\S 2032 \mathrm{~A}$ 's Special

Valuation of Real Property $\quad \ldots \ldots \ldots \ldots \ldots \ldots \ldots \ldots$

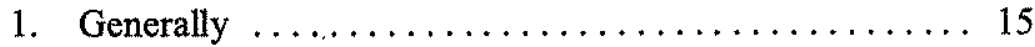

2. Passing From Decedent to Qualified Heir ......... 18

3. "Qualified Use" $\ldots \ldots \ldots \ldots \ldots \ldots \ldots \ldots \ldots \ldots$

4. Percentage Requirements ................ 20

C. Payment of Taxes-I.R.C. $\S 6166$ 's Extension of Time for

Payment of Estate Taxes . . . . . . . . . . . . . . . 23

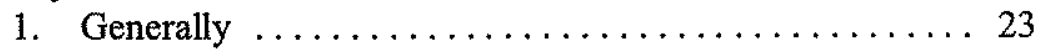

2. Attribution Rules ...................... 25

D. A Spectrum of Definitions $\ldots \ldots \ldots \ldots \ldots \ldots \ldots \ldots \ldots \ldots \ldots \ldots \ldots$

II. Family Heritage: The Origins of the Estate Tax Constructions of Family . . . . . . . . . . . . . . . . . . . . . 29

A. Estate Tax Inclusion: I.R.C. $\$ 2036 \ldots \ldots \ldots \ldots \ldots \ldots, 30$

B. Estate Tax Valuation: 1.R.C. $\S 2032 \mathrm{~A} \ldots \ldots \ldots \ldots \ldots \ldots, 32$

C. Estate Tax Payment: I.R.C. $\S 6166 \ldots \ldots \ldots \ldots \ldots \ldots \ldots 34$

* Associate Professor, Pace University School of Law. B.A. 1991, Yale University. J.D. 1996, University of Pennsylvania Law School. Associate, Milbank, Tweed, Hadley \& McCloy LLP, Trusts \& Estates Department 1996-2003. For helpful comments and conversations, I thank Jonathan G. Blattmachr, David N. Cassuto, Don Doernberg, James L. Flannery, Bennett L. Gershman, Joshua F. Greenberg, Lissa Griffin, Anthony C. Infanti, Ronald H. Jensen, Darryll K. Jones, Nannette Morrison, Darren Rosenblum and Harry $\mathrm{E}$. White. Marisa DeVito, Erica Gerlando and Aryeh Kurz provided able research assistance. 
III. Family Values: Perspectives on the Family $\ldots \ldots \ldots \ldots \ldots \ldots 36$

A. Tax Rules and Interconnectedness $\ldots \ldots \ldots \ldots \ldots \ldots \ldots, \ldots \ldots$

B. Tax Rules and Diversity in Families . . . . . . . . . . . 42

1. How the Definitions Succeed $\ldots \ldots \ldots \ldots \ldots \ldots, 42$

2. How the Definitions Fail $\ldots \ldots \ldots \ldots \ldots \ldots \ldots, 42$

C. Tax Rules and Market Participation .............. 47

IV. Family Unity: Proposals to Resolve the Estate Tax's Conflicting Definitions of Family $\ldots \ldots \ldots \ldots \ldots \ldots \ldots \ldots \ldots \ldots, 48$

A. Adopt a Uniform Definition of Family ............. 49

1. Adopt I.R.C. $\$ 2036$ (b)'s Narrow Definition ......... 50

2. Adopt I.R.C. $\$ 2032 \mathrm{~A}$ 's Broad Definition .......... 52

B. Eliminate All Family-Based Preferences and Penalties ..... 55

C. Eliminate the Family-Based Preferences . . . . . . . . . . . 57

D. Increase the Estate Tax Exemption .............. 58

E. Revise Terminology to Achieve Statutory Integrity $\ldots \ldots \ldots 60$

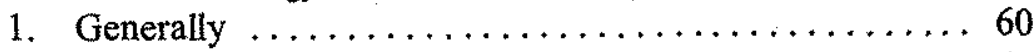

2. Revisions to I.R.C. $\S 2036 \ldots \ldots \ldots \ldots \ldots \ldots \ldots \ldots$. . . . 61

3. Revisions to I.R.C. $\S 2032 \mathrm{~A} \ldots \ldots \ldots \ldots \ldots \ldots \ldots \ldots 66$

4. Revisions to I.R.C. $\S 6166 \ldots \ldots \ldots \ldots \ldots \ldots \ldots \ldots 64$

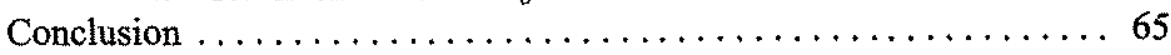

Appendix $\ldots \ldots \ldots \ldots \ldots \ldots \ldots \ldots \ldots \ldots \ldots, 68$ 


\section{INTRODUCTION}

You can choose your friends but the Internal Revenue Code chooses your family, at least for estate tax purposes. In broad terms, the estate tax. provisions of Chapter 12 of the Internal Revenue Code ${ }^{1}$ impose a tax on any gratuitous death-time transfer by an individual. ${ }^{2}$ For the most part, precise tax liability will depend on the amount of the transfer. ${ }^{3}$ Estate tax liability also may depend on the identity and even the business activities of the transferor, the transferee and each of their respective "family" members. ${ }^{4}$ Depending on the particular Code section involved, ${ }^{5}$ however, the term "family" has widely divergent meanings for estate tax purposes. ${ }^{6}$ Indeed the federal estate tax laws employ terms like "family" and "related" in ways that conflict with each other and with lay understandings of the word. ${ }^{7}$ A uniform definition would make

1. I.R.C. $\$ \S 2001-2210$.

2. Id. $\S 2001$ (a) ("A tax is hereby imposed on the transfer of the taxable estate of every decedent who is a citizen or resident of the United States.").

3. See id. § 2001(b) (computation of estate tax).

4. See infra notes 97-101 and accompanying text; see also infra Part I.B.3 (for purposes of $\S 2032 \mathrm{~A}$, "qualified use" of property may be by decedent or certain members of decedent's family).

5. The discussion here is limited to three specific estate tax provisions: $\$ \$ 2036(\mathrm{a}), 2032 \mathrm{~A}$ and 6166. There are other tax rules in which the definition of "family" plays an important role, but they are beyond the scope of this discussion. See, e.g., I.R.C. $\$ 2057$ (deduction for family-owned business interests); see also infra note 7.

6. See infra notes $27,39-43,72-77,125-27$ and accompanying text.

7. The estate tax definitions of "family" conflict not only with each other, but with the way the same term is used in other parts of the Code, inchuding the gift tax-like provisions of Chapter 14 and the generation-skipping transfer tax rules of Chapter 13. See, e.g., I.R.C. $\$ \$ 2701$ (special valuation rules in case of transfers of interests in corporations or partnerships), 2702 (special valuation rules in case of transfers of interests in trust), 2704 (treatment of certain lapsing rights and restrictions); cf. id. $\$ \S 267$ (income tax limitation on deductions for losses on transactions between related taxpayers), 2651(e) (for generation-skipping transfer tax purposes, special generation assignment rules in the case of persons with a predeceased parent), 1361 (income tax definition of $S$ corporation), 1563(e) (constructive ownership rules for purposes of definition of "controlled group of corporations" and limitation on multiple income tax benefits). Since the enactment of the American Jobs Creation Act of 2004, Pub. L. No. 108-357, $\$ 232$, 118 Stat. 1418, 1434 (codified at LR.C. § 1361(b)(1)(A)), S corporations may have 100 shareholders (the limit previously was 75). For purposes of the shareholder limit of $\$ 1361$, "family" members are treated as one shareholder. I.R.C. $\$ 1361$ (c)(I)(A)(ii). "Family" includes all lineal descendants and spouses or former spouses of all lineal descendants of a common ancestor not more than six generations from the youngest shareholder who otherwise would be considered a member of the family. Id. $\$ 1361(\mathrm{c})(1)(\mathrm{B})(\mathrm{i})$-(ii). There has not yet been any significant scholarship on the American Jobs Creation Act of 2004. For practitioner-oriented discussions of the recent changes to $\$ 1361$, see Matthew A. Melone, $\$$ Corporation Rules Liberalized by the American Jobs Creation Act of 2004, Bus, EntrTres, Mar.-Apr. 2005, at 20; Joy M. Miyasaki, Estate Planning Update, in Advanced Estate Planning TeChniQues 2005, at 1 (ALI-ABA CLE, Course of Studies Material No, SK059, 2005); Stefan F. Tucker \& Brian S. 
the law easier to apply, but it would result in systematic over-taxation or under-taxation. Instead the statutes should be revised to use unique terms that apply for limited purposes.

To explore the conflicting estate tax meanings of family, Part I of this Article examines in detail three complex Code sections. ${ }^{8}$ Part I first examines $\S 2036(a)^{9}$ and its rule for the estate tax inclusion of assets over which a taxpayer-decedent retains benefit or control. ${ }^{10}$ Part Inext examines $\$ 2032 \mathrm{~A}$ 's special valuation rule for real estate ${ }^{11}$ before turning to a third Code section,

Masterson, Recent Developments Affecting Real Estate and Pass Through Entities, in SEVENTH ANNUAL REAL ESTATE TAX Forum 11 (PLI Tax Law \& Est. Plan. Practice Course, Handbook Series No. 644, 2005).

8. See supra note 5. As a related matter, the discussion of the conflicting meanings of family in estate tax law also invites larger questions, beyond the scope of this Article, about the underlying purpose of wealth transfer taxation. Those who favor the tax believe that estate taxation is a crucial tool of economic redistribution, needed to break up concentrations of inherited weal th: "IIf the diffusion of wealth is to be preferred to its concentration in the hands of those who have not produced it -and this seems to be the prevailing trend of public opinion-the inheritance tax offers a simple expedient for bringing about that result." Peter V. Ross, Inheritance Taxation, 19 CASE \& COMMENT 452, 453 (1913), quoted in IRA Mark Bloom et al., Federal TaXatron of Estates, Trusts, and Gifts 12 (3d ed. 2003); see also Andrew Carnegie, Wealth, 391 N. AM. Rev, 653,659 (1889) ("By taxing estates heavily at death the State marks its condemnation of the selfish millionaire's unworthy life."). Proponents of the estate tax also describe the tax as the price a citizen pays for a democratic political system that protects economic and personal freedoms. BLOOM, supra, at 2l-22 ("Men who continue hoarding great sunis all their lives, the use of which for public ends would work gool in the community from which it chiefiy came, should be made to feel that the community, in the form of the State, cannot thus be deprived of its share."); see also WILLIAM H. GATES, SR.\& ChUCK COLLINS, WEALTH AND OUR COMMONWEALTH: Why AMERICA Should TAX ACCUMULATED FORTUNES, at Xi (2002) ("Americans who possess great wealth have a special obligation to pay back a debt to society."). In contrast, those who oppose the estate tax believe that it improperly penalizes success and unjustly infringes on personal property rights.

[T] The right to transfer wealth has the positive values of fostering incentives in the form of rewarding

industry, ingenuity and creativity, encouraging capital formation through savings and investment, permitting continuity of ongoing en terprise, and supporting diversity in priorities. In addition, such transfers are, indeed, often justified by significant, if not always evident, economic contributions by those who receive them.

Ross, supra, at 13. The Congressional Budget Office has suggésted that "[e]conomic studies have had limited success in identifying how the estate tax may influence the behavior of farmers and small-business owners .... A large body of research has found that income taxes may discourage entrepreneurial effort .... [T] The estate tax may also reduce entrepreneurial effort." CONG. BUDGET OFFICE, EFFECTS OF THE FEderal Estate TaX ON Farms and SMALI BUSINEsses, at viii (2005). Each of these positions is deeply felt by ordinary citizens and politicians alike. Against this backdrop, Congress engages in heated debates over the future of the estate tax. Joel Havemann, A Rare Accord: Almost Everyone Dislikes Budget, L.A. TrMEs, July 31, 2005, at A-31.

9. I.R.C. $\$ 2036$ (a) (inclusion in gross estate the value of transfers with respect to which the decedent retained the right to "the possession or enjoyment of, or the right to income from, the property, or the right, either alone or in conjunction with any person, to designate the persons who shall possess or enjoy the property or the income therefrom.").
10. $x d$.
11. Id. $\$ 2032 \mathrm{~A}$. 
$\S 6166$, and its rule for a ten-year ${ }^{12}$ extension of time to pay estate tax if the requisite percentage of a decedent's estate consists of "family"-owned business interests and meets other tests. ${ }^{13}$ Under each of these sections, family is defined differently, making mastery and application of the law excessively challenging.

Part II of this Article explores the legislative history of each of $\S \S 2036$ (a), 2032A and 6166 in an effort to elucidate the relationship between the purpose and function of these Code sections and their unique definitions of "family." Each Code section operates differently in the estate tax system. Section 2036(a), for example, functions to determine the scope of the gross estate, causing estate tax inclusion where a decedent maintains a certain level of control over transferred property. Section $2032 \mathrm{~A}$, in contrast, is a valuation rule that aims to reduce estate tax and enhance the probability of a family"s retaining ownership of a farm or other business. Finally $\S 6166$ is an estate tax payment rule that carefully defines the types of taxpayers who will have more time to pay taxes.

Part III moves beyond an analysis of the specific Code sections to a discussion of contemporary experiences of the family. Many modern families do not resemble the traditional model of two married parents with shared children. ${ }^{\text {is }}$ Although the estate tax rules contemplate some family structures that depart from the traditional model, they do not acknowledge, let alone accord tax benefits to, the full range of associational relationships that function in fact as "families." This Part critiques the estate tax law's

12. This ten-year extension may be combined with the deferral under $\S 6166(a)$ (3). Under $\S 6166(a)(3)$, "the executor may elect to defer paying the tax attributable to a closely held business interest for up to five years." Borus I. BitTKER ET AL., Feder AL Estate AND Gift TAXation 715 (8th ed. 2000). Because of the overlap in the first year of the ten-year and five-year periods, the cumulative extension may last up to fourteen years. I.R.C. $\$ 6166$ (a)(1)-(3). See generally BITTKER ET AL., supra, at 715 .

13. I.R.C. $\$ 6166(a)$ (1) (estate may be eligible for a defermal in the payment of estate tax where the value of a "closely held business" exceeds $35 \%$ of the adjusted gross estate). See infra note 107 and accompanying text.

14. See infra Part II.

15. See infra Part III.

16. For example, pursuant to the Defense of Marriage Act, Pub. L. No. 104-199, 110 Stat. 2419 (1996) [hereinatter DOMA], signed by President Clinton in 1996, for federal law purposes, "the word 'marriage' means only a legal union between one man and one woman as husband and wife, and the word' 'spouse' refers only to a person of the opposite sex who is a husband or wife." 1 U.S.C. \$ 7 (2006). Notwithstanding a particular state's rules allowing same-sex couples to many, then, the couple seemingly would not be considered married for federal tax purposes. For a superb comprehensive discussion of tax, estate planning and other legal issues facing same-sex couples, see Derek B. Dorn, Navigating the SameSex Marriage Landscape, 38 N.Y. ST. B.A. TR. \& EsT. SECTION NEWSLETTER 16 (2005). For a scholarly discussion of constitutional aspects of DOMA, see, for example, Deborah A. Batts, Repeal DOMA, 30 
approaches to defining the family and suggests that the Code misunderstands how families function in fact.

Part IV considers solutions to the conflicting estate tax definitions of family. This Part first addresses the possible adoption of a uniform definition of family for estate tax purposes. ${ }^{17}$ Because each of $\S \S 2036,2032 \mathrm{~A}$ and 6166 intends to accomplish very different results, a single definition of family would result in the taxation of too few transactions or too many transactions. This Part also considers eliminating rules that penalize taxpayers or award preferences to them based on family relationships, eliminating only the preferential provisions and increasing the estate tax exemption. Increasing the estate tax exemption may decrease the number of estates affected by the complex laws, but does nothing to solve the larger problem. These proposals are individually and collectively incomplete. Part IV instead embraces a fifth proposal to revise the statutes to use terms like Attribution Group, Qualified Heir Group and Closely Held Business Associates in place of "family" and "related" persons. These unique terms will minimize complexity, help achieve statutory integrity and bring the estate tax definitions in line with the rules' underlying policies.

Hum. Rrs. 2 (2004); Brett P. Ryan, Love and Let Love: Same-Sex Marriage, Past, Present and Future, and the Constitutionality of DOMA, 22 U. HAW. L. REV. 185 (2000); Mark Strasser, DOMA and the Two Faces of Federalism, 32 CREIGHTON L. REv. 457 (1998); Mark Strasser, The Privileges of National Citizenship: On Saenz, Same-Sex Couples and the Right to Travel, 52 RUTGERs L. REV. 553 (2000); Evan Wolfson \& Michael F. Melcher, The Supreme Court's Decision in Romer v, Evans and Its Implications for the Defense of Marriage Act, 16 QUINNPIAC L. REv. 217 (1996); Note, Litigating the Defense of Marriage Act: The Next Battleground for Same-Sex Marriage, 117 HARv. L. Rev. 2684 (2004); Anita Y. Woudenberg, Note, Giving DOMA Some Credit: The Validty of Applying Defense of Marriage Acts to Civil Unions Under the Full Faith and Credit Clause, 38 VAL. U. L. REV. 1509 (2004).

17. Although beyond the scope of this Article, the same reasoning would tend to suggest the rejection of a uniform definition of family for all wealth transfer tax purposes (i.e., gift, estate and generation-skipping taxes). 


\section{Family Conflict: Varied Definitions of "Family" in Estate TAX LAW}

\section{A. The Scope of the Gross Estate}

\section{I.R.C. $\$ 2036(a)(1)$ and I.R.C. $\$ 2036(b)(2):$ Transfers With a Retained Interest}

The basic rule of $\S 2036(a)(1)$ is that a decedent may not avoid estate taxation if he or she transfers property to another but retains some benefit from the property. Specifically under $\S 2036(a)(1)$, the value of a decedent's gross estate includes the value of "all property to the extent of any interest therein of which the decedent has at any time made a transfer . . . by trust or otherwise, under which he has retained ... the possession or enjoyment of, or the right to the income from, the property." interest is a life estate. ${ }^{19}$ Thus in the case of a hypothetical taxpayer, $X$, who transfers assets to a trust to pay income to $X$ for life, remainder to $X$ 's daughter, all of the assets in the trust will be included in $X$ 's gross estate upon $X$ 's death, ${ }^{20}$ because $X$ retained the right to income from the property. A similar but less well-known example of a retained right that will cause estate tax inclusion under $\S 2036(\mathrm{a})(1)$ is the right (whether direct or indirect) to vote shares of stock in a "controlled corporation."21 For example, where $X$

18. I.R.C. $\$ 2036(a)(1)$. The decedent's retention may be for life or "for any period not ascertainable without reference to his death or for any period which does not in fact end before hís death." Id. A period not ascertainable without reference to the decedent's death exists where the taxpayer retains the right to periodic payments of income from transferred property, subject to the condition that the decedent's right to receive income terminates at the conclusion of the last full period immediately prior to death. Treas. Reg. $\$ 20.2036-1$ (b)(1)(i) (as amended in 1960); see also STEPHANIE J. WILLBANKS, FEDERAL TAXATION OF WEALTH TRANSFERS 241-42 (2004).

19. See I.R.C. $\$ 2036($ a)(1); Treas. Reg. $\$ 20.2036-1$ (a) (as amended in 1960). For a thorough analysis of the application of $\$ 2036$ (a) to a line of cases involving family limited partnerships, see Ronald H. Jensen, The Magic of Disappearing Wealth Revisited: Using Family Limited Partnerships to Reduce Estate and Gift Tax, 1 PITT. TAX. REV. 155 (2004).

20. Note that the full value of the trust will be inciuded in the decedent's gross estate even though her transfer to the trust was complete for gift tax purposes. See I.R.C. $\$ 2501$ (a) (imposition of tax on gifts); Treas. Reg \$25.2511-2(b) (as amended in 1999) (gift is complete where donor "has so parted with dominion and control as to leave in him no power to change its disposition, whether for his own benefit or for the benefit of another. ...'). Under $\$ 2702$, the value of the transferor's retained interest is valued at zero. I.R.C. $\$ 2702$. See generally WILLBANKS, supra note 18 , at 243; RICHARD B. STEPHENS ET AL., FEDERAL Estate and GiFT TAXATion $\$ 4.08[4]$ [a] (8th ed, 2002).

21. IR.C. $\$ 2036(a)(1)$, (b)(1). Forother examples of retained interests (other than income interests) that can trigger estate tax inclusion under $\$ 2036(\mathrm{a})(1)$, see Estate of Rapelje v. Comm'r, 73 T.C. 82 (1979) (decedent's retention of right to reside in home after transfer to family members causes estate tax inclusion); 
transfers stock in a "controlled corporation" to a trust for the benefit of $X$ 's son, if $X$ retains the right (whether outright or in a fiduciary capacity) to vote those shares, the value of the shares will be included in $X$ s gross estate upon $X$ 's death. ${ }^{22}$

The definition of a "controlled corporation" is bound inextricably with the definition of family. Section 2036(b)(2) defines a controlled corporation as one in which the decedent "owned (with the application of section 318), or had the right (either alone or in conjunction with any person)" to vote stock carrying at least $20 \%$ of the aggregate voting power of all stock classes. ${ }^{23}$ To illustrate, consider a transfer by another hypothetical taxpayer, this time Dora Ewing, a United States citizen who is married and has two adult children. She and her ancestors, descendants and collateral relatives are shown in Figure A. Each person's relationship to the taxpayer is indicated in italics.

Estate of Maxwell v. Comm'r, 3 F.3d 591 (2d Cir. 1993) (decedent's transfer of home to family members is not a bona fide sale for full and adequate consideration where decedent's rent payments approximate amounts due under mortgage and past due rent was not collected).

22. I.R.C. $\$ 2036(a)(1),(b)(1)$. The estate tax inclusion applies if the voting right is held at death. In addition, it may apply if the voting right was held within three years of death. See 1.R.C. $\$ 2035$ (a); STEPHENS ET AL., supra note 20, $14.08[6][d]$.

23. I.R.C. $\$ 2036(\mathrm{~b})(2)$. Ownership is defined for purposes of $\$ 2036(\mathrm{~b})(2)$ by reference to $\$ 318$. See infra notes $26-27$ and text accompanying note 31 . It is immaterial whether the voting right is exercisable by the decedent alone or in conjunction with another person. I.R.C. $\$ 2036(\mathrm{~b})(2)$. 
Figure A

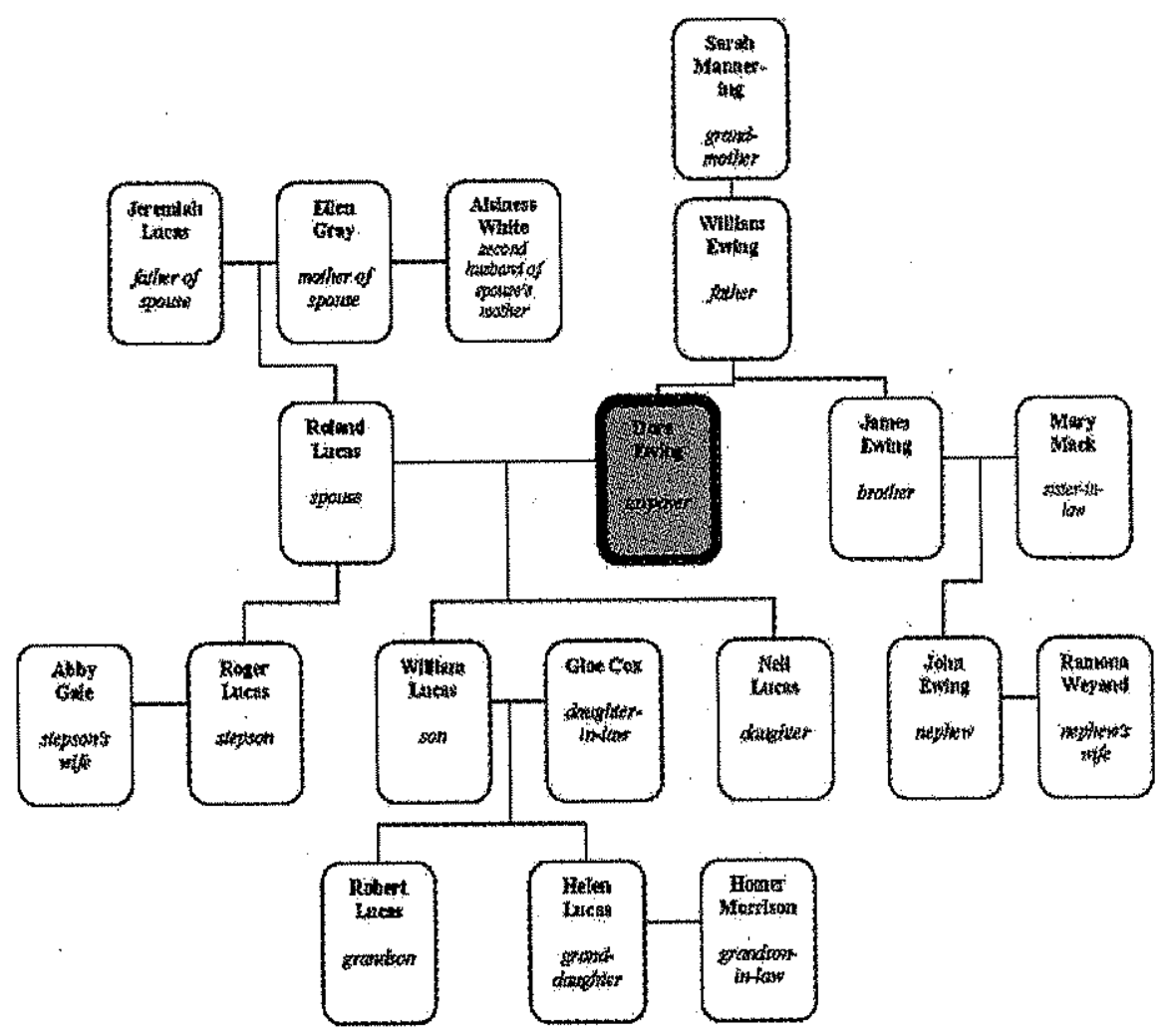

Hypothetical 1. Assume that Dora Ewing owns $20 \%$ of Company Y's total outstanding stock. Company $\mathrm{Y}$ has only one class of stock, and all shares have the same voting rights. Pursuant to Company Y's by-laws and the applicable shareholder agreement, any shareholder may transfer an underlying equity interest in stock without also transferring the voting rights associated with the stock. One year before her death, Dora Ewing transfers to Friend Frank, an unrelated third party not shown in Figure A, the underlying equity interest in all of her Company $Y$ stock. At the time of her death, Dora Ewing retains the right to vote the shares.

Because Dora Ewing transfers to Friend Frank her underlying equity interest in the stock, but retains the right to vote the shares, she has at her death the right to vote at least $20 \%$ of the total combined voting power of Company $Y$ stock. This is true even though she no longer owns the underlying equity. Therefore, within the meaning of $\S 2036(\mathrm{~b})(2)$, Company $\mathrm{Y}$ is a controlled 
corporation with respect to Dora Ewing. ${ }^{24}$ Her retained right to vote shares in a controlled corporation constitutes a right to possession or enjoyment of transferred property for purposes of $\S 2036$ (a) (1), causing the full value of the Company Y stock to be included in Dora Ewing's gross estate. ${ }^{25}$

Note that $\S 2036$ (b)(2)'s definition of a controlled corporation focuses on the ownership of more persons than just the taxpayer-transferor. This section invokes the constructive ownership rules of $\S 318^{26}$ for the determination of a taxpayer-transferor's ownership. Under $\S 318$, an individual is deemed to own any stock that is owned (whether directly or indirectly), by or for "(i) his spouse (other than a spouse who is legally separated from the individual under a decree of divorce or separate maintenance), and (ii) his children, grandchildren, and parents. ${ }^{27}$ For purposes of $\S 2036(\mathrm{~b})(2)$ 's definition of controlled corporation, then, examination must be made of the holdings of the taxpayer-transferor, his or her spouse, children, grandchildren and parents. Even if the taxpayer personally owns a very small percentage of the stock (or even none at all), and the corporation initially does not appear to be a "controlled corporation" with respect to the taxpayer, the attribution to the taxpayer of the holdings of his or her family members can have unexpected consequences. ${ }^{28}$ Consider again the family of Dora Ewing.

Hypothetical 2. Assume the same facts as in Hypothetical 1, except that Dora Ewing owns $5 \%$ of Company Y's total outstanding stock. Dora Ewing again transfers to Friend Frank her underlying equity interest in all of her Company $Y$ stock. At the time of her death, Dora Ewing retains the right to vote the shares and her father, William Ewing, owns $95 \%$ of the Company Y stock.

At first glance it might appear that Dora Ewing can avoid the application of $\S 2036(\mathrm{~b})(2)$ (and therefore $\$ 2036(\mathrm{a})(1)$ ) because she personally has the right to vote only five percent of Company $Y$ stock. ${ }^{29}$ Unfortunately for Dora Ewing, under the constructive ownership rules of $\S 318$ she owns her father's $95 \%$ interest, making Company $\mathrm{Y}$ a controlled corporation with respect to her. ${ }^{30}$ Thus as in Hypothetical 1, the full value of the stock transferred to

24. I.R.C. $\$ 2036(b)(2)$.

25. Id. $\$ 2036(a)(1)$.

26. Id. $\$ 2036(\mathrm{~b})(2)$.

27. Id. $\$ 318(a)(1)(A)$. On gender-neutrality in the Code, see $i d . \$ 7701(0)(1)(3)$ and 1 U.S.C. $\$ 1$ (2006) ("words importing the masculine gender include the feminine as well").

28. I.R.C. $\S 2036(\mathrm{~b})(2)$.

29. Id.

30. Id. The statutory language of $\$ 2036$ (b)(2) makes the attribution rules of $\$ 318$ applicable only to a determination of ownersh ip levels. In contrast, the proposed regulations under $\$ 2036$ suggest that the 


\author{
Friend Frank will be included in Dora Ewing's gross estate under \\ $\S 2036(\mathrm{a})(1) .^{31}$
}

attribution rules apply to determination of stock ownership and voting rights. Prop. Treas. Reg. $\$ 20.2036-2$ (d)(1), 48 Fed. Reg. 35,143 (Aug. 3, 1983) ("For purposes of this section, the term "controlled corporation' means a corporation in which the decedent, with the application of the constructive ownership rules of section 318 , is deemed to own or have a right to vote stock possessing at least twenty percent of the total combined voting power of all classes of stock."). At least one treatise suggests that this proposed regulation is "drafted too broadly also in permitting use of Section 318 attribution to determine the portion of voting rights. Prop. Reg. $\$ 20.2036-2$ (d)(1) should be amended to permit attribution only to detemine ownership, not to determine voting rights." STEPHENS ET Al., supra note 20, $14.08 \mathrm{n} .97$; see also PAUL R. MCdaniel. et al., Federal Wealth Transfer Taxation 247 (5th ed. 2002) ("Prop. Reg. $\S 20.2036-2(d)(1)(1983)$ appears to apply the attribution rules of $\S 318$ to the voting power as well as to the ownership test, a questionable interpretation of $\$ 2036(\mathrm{~b})$."); MYRON KOVE \& JAMES KOSAKOW, HANDLING FEDERAL ESTATE \& GIFT TAXES 2-197 (6th ed. 2004) (" $t$ t]he constnuctive ownership rules of I.R.C. $\$ 318$ would not be used to attribute retention of voting rights to the decedent"); Steve R. Akers, Selection of Trustees: A Detailed Review of Gift, Estate and Income Tax Effects and Non-Tax Effects, 38 U. MIAMI INST. ON EST. PLAN. 3-1, 3-57 (2004) ("the mere fact that persons whose ownership of stock would be attributed to the grantor under Section 318 have the right to vote stock will not be treated as a retention of voting power by the granter"); cf. NORMAN H. LANE \& HOWARD ZARITSKY, FEDERAL. INCOME TAXATION OF ESTATES AND TRUSTS 11-23 (3d @. 2003) (claiming without analysis that attribution rules apply to a determination of voting tights); Susan C. Frunzi, The Federal Estate Tax, in UNDERSTANDING ESTATE, GifT \& Generation-Skipping TRansfer TAXES 2002, at 95, 117-18 (RLI NY Practice Skilis Course, Handbook Series No. 118, 2002) (claiming without analysis that the attribution rules apply to a determination of voting rights).

The proposed regulations under $\$ 2036$ are promulgated pursuant to the general interpretative authority granted to the Treasury Department under $\$ 7805$ (a). Although interpretive regulations do not have the force of law, they nevertheless may be given substantial deference by an interpreting court if the statute is found to be ambiguous. See Chevron, U.S.A, Inc. v. Natural Res. Def. Council, Inc., 467 U.S. 837,844 (1984) (legislative regulations are valid unless "arbitrary, capricious, or manifestly contrary to the statute"); see also Mitchell M. Gans, Deference and the End of Tax Practice, 36 Real. Prop. Prob. \& TR. J. 731, 751 (2002) ("Under Chevron, once a court finds that a statute is ambiguous, the court is obliged to defer to any reasonable resolution of the ambiguity embodied in a regulation-mprovided Congress contemplated that the agency would have interpretive authority and the agency issues its interpretation in a format Congress anticipated would be binding on the courts."). Where a statute directly addresses a question, however, a regulation "is not considered such a permissible construction or reasonable interpretation unless it harmonizes both with the statutory language and with the statute's origin and purpose." Walton v. Comm'r, 115 T.C. 589, 598 (2000). In this case, Prop. Treas. Reg. $\$ 20.2036-2$ (d)(1), 48 Fed. Reg. 35,143 (Aug. 3, 1983), seems to directly contradict the statute and therefore likely would not be considered a permissible construction of $\S 2036$. Nevertheless, as the language of the proposed regulations indicates the Service's litigating position with respect to the aggregation of voting rights, the proposed regulations should be taken into account.

31. I.R.C. $\$ 2036(\mathrm{~b})(1)$-(2). For the purposes of detemining what is a controlled corporation within the meaning of $\S 2036(b)(2)$, reattribution rules may apply to render an entity a controlled corporation with respect to a decedent. $I d . \S 318(\mathrm{a})(5)(\mathrm{A})$. Section 318 provides not only that an individual is deemed to own the stock held by the individual's spouse, children, grandchildren and parents, $i d$. $\$ 318(\mathrm{a})(1)$, but also that stock owned directly or indirectly by a partnership, estate, trust or corporation may be attributed to the partners, beneficiaries or owners. Id. \$318(a)(2)(A)-(C). In other words, there are circumstances in which a decedent may be deemed to own stock held in trust for the benefit of a family member. Id. $\$ \$ 318(\mathrm{a})(2)(\mathrm{B}), 2036(\mathrm{~b})(2)$. To illustrate, consider a variation on Hypothetical 2 above. 
2. I.R.C. $\S 2036(a)(2):$ Transfers With a Retained Right to Designate Possession or Enjoyment of Property

Just as $\S 2036(a)(1)$ includes in a decedent's gross estate property with respect to which the decedent retained certain benefits from the transferred property, ${ }_{3}^{32} \S 2036(\mathrm{a})(2)$ includes in a decedent's gross estate the value of all property to the extent that the decedent retains the right to designate the persons who benefit from the transferred property. ${ }^{33}$ Estate tax inclusion under $\S 2036(\mathrm{a})(2)$ commonly arises in situations in which a transferordecedent retains discretionary authority over assets transferred to a trust. ${ }^{34}$ There are also situations where a transferor-decedent retains rights to remove and replace a person (typically a trustee) who has the authority to make discretionary distributions of assets transferred to a trust. ${ }^{35}$ Specifically, the

Hypothetical 21/2. Assume the same facts as in Hypothetical 1, except that Dora Ewing owns 5\% of Company Y's total outstanding stock. Dora Ewing again transfers to Friend Frankher underlying equity interest in all of her Company $Y$ stock. Dora Ewing retains the right to vote the shares. At the time of Dora Ewing's death, $95 \%$ of the Company Y stock is held in a trust. Dora Ewing's father, William Ewing, holds a present interest and a vested remainder in the trust. His interest has an actuarially-computed value equal to $100 \%$ of the trust property.

Through application of the reattribution rules, Company $Y$ will be considered for purposes of $\S 2036(b)(2)$ to be a controlled comoration with respect to Dora Ewing. First, the stock beld in the trust for William Ewing's benefit is attributed to William Ewing under $\$ 318(\mathrm{a})(2)(\mathrm{B})(\mathrm{i})$. That section provides that "[s $\mathrm{s}$ tock owned, directly or indirectly, by or for a trust ... shall be considered as owned by its beneficiaries in proportion to the actuarial interest of such beneficiaries in such trust." $I d . \& 318(a)(2)(B)(i)$. Second, under the constructive ownership rules of $\$ 318$, she owns her father's $95 \%$ interest, making Company $\mathrm{Y}$ a controlled corporation with respect to her. $I d$. $\S \S 318(\mathrm{a})(\mathrm{l})$ (A)(ii) (an individual is deemed to own stock owned directly or indirectly by a parent), $2036(\mathrm{~b})(2)$.

32. See supra note 18 and accompanying text.

33. I.R.C. $\$ 2036(a)(2)$ (emphasis added). Specifically, $\$ 2036(\mathrm{a})(2)$ provides that the decedent must have retained this interest for life or any pexiod not ascertainable without reference to the decedent's death or any period that does not end before the decedent's death. See supra note 18 and accompanying text.

34. United States v. O'Malley, 383 U.S. 627 (1966) (finding estate tax inclusion where transferordecedent retained the right as trustee to pay or accumulate trust income for a beneficiary); Old Colony Trust Co. v. United States, 423 F.2d 601 (1st Cir. 1970) (finding estate tax inclusion where transferot-decedent retained the right as trustee to increase payments of trust income if "desirable in view of changed circumstances"). It is irrelevant for purposes of $\S 2036(\mathrm{a})(2)$ whether this power is retained outright or in a fiduciary capacity, whether the power is exercisable alone or in conjunction with others or whether the exercise was subject to an uncontrollable contingency that does not occur in fact. Treas. Reg. $\$ 20.2036-1(\mathrm{~b})$ (3) (as amended in 1960); $c f$. Rev. Rul. 95-58, 1995-2 C.B. 191 (ruling with respect to a grantor's reserved power to remove and replace a trustee that "it is immaterial in what capacity the power was exercisable by the decedent.").

35. See, e.g., Estate of Farrel v. United States, 553 F.2d 637 (Ct. Cl 1977) (trust assets are included in transferor-decedent's gross estate under $\$ 2036$ (a)(2) where transferor-decedent retained the right to 
Service takes the view that if a transferor-decedent has the power to remove a trustee and replace the removed trustee with a family member who is "related or subordinate" to the transferor within the meaning of $\$ 672$ (c) (and to be "related or subordinate," one must also be "nonadverse"), the trust assets will be included in the decedent's gross estate. ${ }^{36}$

Under $\S 672(\mathrm{c})$ a related or subordinate party is one who is both (a) "nonadverse" and (b) a member of a specific class of individuals. ${ }^{37} \mathrm{~A}$ nonadverse party is a person who does not have any "substantial beneficial interest" in a trust that would be adversely affected by the exercise or nonexercise of a power with respect to that trust. ${ }^{38}$ The specific class of individuals includes the taxpayer's spouse ${ }^{39}$ father, mother, issue, brother or

appoint a successor trustee, and neither state law nor the trust instrument would prohibit transferor from appointing herself as trustee); $c f$. Estate of Wall v. Comm'r, 101 T.C. 300 (1993) (trust assets are not included in transferor-decedent's gross estate under $\$ 2036(\mathrm{a})(2)$ where transferor-decedent retained the right to remove a corporate trustee and replace it with another independent corporate trustee).

36. Rev. Rul. 95-58, 1995-2 C.B. 191. Note, however, that Revenue Ruling 95-58 focuses not on the initial appointee, but the class of persons from whom the taxpayer-grantor could choose a successor. On the meaning of "nonadyerse," see infra note 38. Although Revenue Ruling 95-58 cites Estate of Wall, 101 T.C. 300, as support, Estate of Wall makes no reference to the income tax concept of "reiated or subordinate" parties within the meaning of $\$ 672(\mathrm{c})$. See also Brief for the American College of Trust and Estate Counsel as Amicus Curiae Supporting Petitioner, Estate of Wall v. Comm'r, 101 T.C. 300 (1993) (No. 15311-91). That language instead seems to be imported from another case cited in Revenue Ruling 95-58, Estate of Vak v. Comm'r, 973 F.2d 1409 (8th Cir. 1992). In Estate of Vak, the court addressed the gift tax consequences of a grantor's retained power to remove trustees and replace them with trustees who were not related or subordinate parties within the meaning of $\$ 672$ (c). Such a power did not cause the gift to be incomplete for gift tax purposes, according to the court. Estate of Vak, 973 F.2d at 1414. Note, however, that as in Revenue Ruling 95-58, Estate of Vak was concemed especially with the class of persons from whon the taxpayer-grantor could choose a successor trustee.

The concept of "related or subordinate" parties is an income tax concept under $\$ 672(\mathrm{c})$ that has been grafted to the estate tax laws for purposes of $\S 2036(\mathrm{a})(2)$. For another example of the ways that income tax rules have been incorporated into estate tax rules, see, for example, Treas. Reg. $\$ 20.2042$ 1(c)(6) (as amended in 1979) (decedent treated as owner of stock held by "any ... trust with respect to which the decedent was treated as an owner under subpart E, part I, subchapter $J$, chapter 1 of the Code immediately prior to his death."). On the validity of Treasury Regulations generally, see Gans, supra note 30, at 733 (demonstrating that in the past, the Intemal Revenue Service has "declared victory by its own regulation").

37. I.R.C. $\$ 672(a)$, (b).

38. Id. Technically a "nonadverse party" is defined as someone who is not an adverse party. Id. $\$ 672(\mathrm{~b})$. An "adverse party" is a person who has a "substantial beneficial interest" in a trust that would be adversely affected by the exercise or nonexercise of a power with respect to that trust. $1 d . \S 672$ (a). Generally speaking, any trust beneficiary will be an adverse party, unless his or her interest is limited to a particular portion of the trust. Treas. Reg. $\$ 1.672(\mathrm{a})-1$ (b) (as amended in 1960). Note, however, that an income beneficiary of a trust may not be "adverse" with respect to a power to be exerised over trust principal. Id. $\$ 1.672(\mathrm{a})-1$ (c). A substantial beneficial interest in a trust is one whose "value in relation to the total value of the property subject to the power is not insignificant." $I d . \S 1.672(\mathrm{a})-1$ (a).

39. For purposes of estate tax inclusion under $\$ 2036(\mathrm{a})(2)$, a spouse is "related" to the taxpayer only if living with the taxpayer. I.R.C. $\S 672$ (c)(1). In contrast, for purposes of subpart E, part I, subchapter $I$, 
sister; ${ }^{40}$ any employee of the taxpayer, ${ }^{41}$ any corporation or employee of a corporation in which the holdings of a taxpayer (or the particular trust in question) "are significant from the viewpoint of voting control"; $;$ and "subordinate" employees of a corporation in which the taxpayer is an executive. ${ }^{43}$

To illustrate this definition of "related," consider the persons shown in Figure A. Assuming that all of them are nonadverse with respect to Dora Ewing, those that are "related" to her include her spouse, Roland Lucas ${ }^{44}$ her father, William Ewing ${ }^{45}$ her daughter, Nell Lucas; ${ }^{46}$ her son, William Lucas; her granddaughter, Helen Lucas; her grandson, Robert Lucas; ${ }^{47}$ and her brother, James Ewing. ${ }^{48}$ The persons in Figure A who are not "related" to Dora Ewing within the meaning of $\S 672(\mathrm{c})$ are her grandmother, Sarah Mannering; her stepson's wife, Abby Gale; her daughter-in-law, Gloe Cox; her grandson-in-law, Homer Morrison; Jeremiah Lucas and Ellen Gray, the parents of her husband, Roland Lucas; Alsiness White, the second husband of Ellen Gray; her sister-in-law, Mary Mack; her nephew, John Ewing; and her nephew's wife, Raymona Weyand. ${ }^{49}$

As this example illustrates, an individual's classification as "related" (or not) does not obtain merely from one's blood relationship (or lack thereof) with the taxpayer. Relational status appears to derive in part from generation assignment and marital status as well. For example, for purposes of $\S 672(\mathrm{c})$ and $\S 2036(a)(2)$, Dora Ewing's father, William Ewing, is "related" to her, but her grandmother, Sarah Mannering, is not. Dora Ewing's spouse, Roland Lucas, is "related" to her for purposes of $\S 672$ (c) only if the spouses are living together, ${ }^{50}$ but Dora Ewing's daughter-in-law, Gloe Cox, and her

chapter 1 of the Code (the grantor trust rules), a grantor is treated as holding any interest or power held by his or her spouse, unless separated under a decree of divorce or separate naintenance. Id. $\$ 672(\mathrm{e})(1),(2)$.

40. Id. $\S 672(\mathrm{c})(2)$.

41. $I d$.

42. Id.

43. Id. For purposes of $\$ 674$ (c), persons are presumed to be "subservient" to the taxpayer unless shown not to be subservient by a preponderance of the evidence. Treas. Reg. $\$ 1.672$ (c)- 1 (as amended in $1960)$.

44. This assumes that Roland Lucas is living with his wife, Dora Ewing. See I.R.C. $\S 672$ (c)(1); see also supra note 39.

45. I.R.C. $\$ 672(\mathrm{c})(2)$.

46. Id. (grantor's "issue")

47. Id.

48. Id.

49. Id.

50. Id. $\$ 672(\mathrm{c})(1)$. 
grandson-in-law, Homer Morrison, are not "related" to Dora Ewing, regardless of whether they cohabitate with their respective spouses (who are "related" to Dora Ewing). ${ }^{51}$ Those blood relatives in the immediately preceding generation (e.g., a parent), the same generation (e.g., a sibling) or younger generations (e.g., a child or grandchild) may be part of the defined class, but those related by marriage, other than a taxpayer's own spouse, are not.

Note also that the class of persons who potentially may be "subordinate" extends without regard to blood relationship. Section $672(\mathrm{c})$ includes in the definition of "subordinate" any employee of the grantor-taxpayer;" a corporation or employee of a corporation "in which the stock holdings of the grantor are significant from the viewpoint of voting control"; 53 and any "subordinate employee of a corporation in which the grantor is an executive." 54 The actual nature of the grantor-taxpayer's family or employment relationships has no bearing on "subordinate" classification for purposes of $\$ 672(\mathrm{c}) .^{55}$ Certain family members and business associates are presumed to be the alter egos of the taxpayer-grantor, making the class of individuals described in $\$ 672$ (c) quite broad.

\section{B. Valuing the Gross Estate-I.R.C. §2032A's Special Valuation of Real Property}

\section{Generally}

While $\S 2036(a)$ is an estate tax inclusion rule, $\S 2032 \mathrm{~A}$ is an estate tax valuation rule. $^{56}$ It is an exception to the basic principle that the estate tax

51. See id. $\$ 672(\mathrm{c})(2)$.

52. Id.

53. Id.

54. Id.

55. Note that for purposes of certain grantor trust rules, negative income tax consequences may derive from a person's being labeled as "related or subordinate" only when that person is also "subservient to the grantor in respect of the exercise or nonexercise of the powers conferred on him unless such part is shown not to be subservient by a preponderance of the evidence." Id. $\$ 672$ (c) (flush language); see id. $\$ \$ 672($ ) (definitions and rules not to result in foreign ownership), 674 (grantor treated as owner of any portion of a trust over which grantor has power to control beneficial enjoyment), 675 (grantor treated as owner of any portion of a trust over which grantor has certain administrative powers).

56. The Joint Committee on Taxation has proposed a change to the way that property is valued for

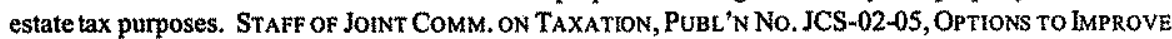
TAX COMPLIANCE AND REFORM TAXEXPENDITURES 396 (2005). Specifically, the Committee has proposed that the gift or estate tax value be determined by reference to the post-transfer value of the transferee's entire interest in the transferned asset. $I d$. at $\mathbf{4 0 0}$. That would mean that a minority interest discount would not be available in cases where the transferee possesses a post-transfer controlling interest in transferred entity. 
value of a decedent's property is its fair market value ${ }^{57}$ as of the decedent's date of death. ${ }^{58}$ Specifically $\$ 2032 \mathrm{~A}$ provides that "qualified real property"s9

Id. at 401. Instead of setting the wealth transfer tax value at "the price at which such property would change hands between a willing buyer and a willing seller, neither being under compusion to buy or to sell, and both having reasonable knowledge of relevant facts," Treas. Reg. $\$ \$ 20.2031-1$ (b) (as amended in 1965), 25.2512-1 (as amended in 1992), the proposal would require an investigation into the actual recipient.

A key aspect of the proposed aggregation rule is a limited form of spousal attribution. STAFF OF JOINT COMM. ON TAXATION, supra, at 404. Under the proposed rule, the interests of spouses are aggregated so that, for example, stock owned by a transferor's spouse is deemed to be owned by the transferor himself or herself Id.

A second proposed change is the suggestion of a "look-through" rule to limit the availability of a discount for lack of marketability. Id. at 401 . Specifically, the proposal provides that in cases where onethird of the value of an entity's assets are marketable, then the wealth transfer tax value of any interest in that entity will be "(1) the net value of the entity's marketable assets allocable to that transferred interest and (2) the value of the transferor's interest in the entity attributable to nonmarketable assets." $I d$. In other words, no lack of marketability discount would be ayailable where one-third of the entity's assets are cash, bank accounts, money market accounts, commercial paper, bonds, and the like. Id.

The staff of the Joint Committee explains that the aggregation rule and the look-through rule intend to "resolve valuation controversies in a simpler and more administrable way." Id. at 2 . The rule attempts to curb "strategic sequencing of multiple gifts made to the same donee," typically in the family context. Id. at 403 . Yet the rules go beyond that and treat husband and wife as one entity for wealth transfer tax valuation purposes. Such an approach is consistent with the system proposed in Bridget $\}$. Crawford, One Flesh, Two Taxpayers: A New Approach to Marriage and Wealth Transfer Taxation, 6 FLA. TAX. REV. $757(2004)$.

57. Fair market value is "the price at which property would change hands between a willing buyer and a willing seller, neither being under any compulsion to buy or to sell and both having reasonable knowledge of the relevant facts." Treas. Reg. \$20.2031-1(b) (1965); see Am. Nat'l Bank \& Trust y. United States, 594 F.2d 1141, 1144 n.2 (7th Cir, 1979) ("V] with the price that it will yield on the market at a given time."). "While not expressly stated in either the Code or regulations, for purposes of valuing real property it is generally accepted that a determining of fair market value requires examination of the price the property could command in its "highest and best use." Stephen E. Zumbach et al, Section 2032A-Special Use Valuation, 833-2d TAX MGMT. (BNA), at A-1 (2003). "Highest and best use refers to the "reasonably probable and legal use of vacant land or improved property, which is physically possible, while appropriately supported, financially feasible, and that results in the highest value." I $d$. (quoting APpralsaL INST., DICTIONARY OF REAL. ESTATE AppraISAL (4th ed. 2002)).

58. I.R.C. $\$ 2031$; Treas. Reg. $\$ 20.2031-1$ (b) (1965); see also Rev. Rul. 74-260, 1974-1 C.B. 275 (detailing mechanics of application of sixth-month rule). A decedent's executor may elect to have the property valued as of the alternate valuation date, which typically is the six-month anniversary of the decedent's date of death. In order to be eligible to value property as of the alternate valuation date, a decedent's executor must make the appropriate election and such election must decrease both the value of the gross estate and the overall estate tax liability. See I.R.C. $\$ 2031,2032$ (c). The Treasury Department recently issued final regulations under $\$ 2032$. See T.D. 9172, 2005-6 I.R.B. 468. For a general discussion of aiternate valuation, see BITTKER ET AL., stpra note 12, at 236-37; STEPHENS ET AL., supra note 20, 14.03; DAVID WESTFALL \& GEORGE P. MAIR, EstaTE PLANNING LAW \& TAXATION 12.02 (4th ed. 2001). Alternate valuation can be an effective means of post-mortem tax planning. See, e.g., JERRY A. KASNER, Post-Mortem TAX PLANNNG (1994); Jonathan G. Blattmachr \& Georgiana J. Slade, More Than One Hundred Post-Mortem Tax Planning Elections, 66 N.Y. ST. B.J. 26, 31 (1994); Robert A. Dawkins, Another Bite at the Apple: Using the Alternate Valuation Election to Restore a Credit Shelter Trust, 16 
may be valued for estate tax purposes at its value for use as a farm for farming purposes or its use in a trade or business other than the trade or business of farming. ${ }^{60}$ In almost all cases, a property's value for farming or trade or business purposes will be less than the property's fair market value. ${ }^{61}$ The estate tax savings resulting from this alternate valuation may be significant. ${ }^{62}$

To be eligible for special valuation rules of $\S 2032 \mathrm{~A}$, an estate must meet five threshold requirements. ${ }^{63}$ First, the decedent must have been a citizen or resident of the United States at the time of his or her death. ${ }^{64}$ Second, the real property must be located in the United States. ${ }^{65}$ Third, the decedent's

ProB. \& Prop. 28 (2002); Ted D. Englebrecht \& James M. Tumer, Alternate Valuation Has Side Effects, 21 EST. PLAN. 154 (1994).

59. I.R.C. $\$ 2032 \mathrm{~A}(\mathrm{~b})(1)$.

60. Id. $\S 2032 \mathrm{~A}(\mathrm{a})(1)$.

61. Estate of Hankins v. Comm'r, 42 T.C.M. (CCH) 229 (1981) (fair market value typically does not take into account actual use of property); see also Dennis 1. Belcher, Estate Planning for Family Business Owners: Section 2032A, Section 6166 and Section 303, in Estate PlanNing In Depth 449, 465-69 (ALI-ABA CLE, Course of Studies MaterialNo. SH092, 2003). Prior to making the election under $\$ 2032 \mathrm{~A}$, the executor is not required to show that the real property had any value other than as a farm or in a trade or business. I.R.S. Announcement 79-143, 1979-42 I.R.B. 28.

62. There is a cap of $\$ 750,000$, adjusted for inflation, on the decrease in value under the special valuation rules. I.R.C. $\$ 2032 \mathrm{~A}(\mathrm{a})(3)$. In 2005 , the inflation-adjusted amount is $\$ 870,000$. Rev. Proc. 2004-71, 2004-50 LR.B. 970.

To illustrate the tax savings that can result from the application of the special valuation rules of $\$ 2032 \mathrm{~A}$; assume unrealistically that a taxpayer dies in 2005 owning only qualified real property. Assume that the property's value for use as a farm for farming purposes is $\$ 9.13$ million but its fair market value is $\$ 10$ million. Assume that the decedent had not made any prior taxable gifts and therefore retained the full applicable credit. The estate's tax liability would be calculated as follows:

\begin{tabular}{|c|c|c|}
\hline & $\begin{array}{c}\text { With } \\
\text { Application of } \\
\S 2032 \mathrm{~A}\end{array}$ & $\begin{array}{l}\text { Without } \\
\text { Application of } \\
\$ 2032 \mathrm{~A}\end{array}$ \\
\hline Taxable estate & $\$ 9,130,000$ & $\$ 10,000,000$ \\
\hline Adjusted taxable gifts & $\underline{0}$ & $\underline{0}$ \\
\hline Total & $9,130,000$ & $10,000,000$ \\
\hline $\begin{array}{l}\text { Tax on taxable estate + adjusted } \\
\text { taxable gifts }\end{array}$ & $4,141,900$ & $4,550,800$ \\
\hline Less applicable credit amount & $\underline{326,300}$ & 326,300 \\
\hline Estate tax due & $\$ 3,815,600$ & $\$ 4,224,500$ \\
\hline
\end{tabular}

In 2005 , estate tax is imposed at a maximum rate of $47 \%$. In 2006 , the maximum rate will be $46 \%$. For 2007,2008 and 2009 , the maximum rate will be $45 \%$. In 2010 , there will be no estate tax. In 2011 , the maximum bracket will revert to $55 \%$. I.R.C. $\$ 2001(\mathrm{c})(2)$.

63. I.R.C. $\$ 2032 \mathrm{~A}(\mathrm{a})(1)$, (b).

64. Id. $\$ 2032 \mathrm{~A}(\mathrm{a})(1)(\mathrm{A})$.

65. Id. $\S 2032 \mathrm{~A}(\mathrm{~b})(\mathrm{l})$. 
executor affirmatively must elect to have $\$ 2032 \mathrm{~A}$ apply to the estate. Fourth, the executor must file the necessary tax recapture agreement. ${ }^{66}$ Fifth, the property must be "qualified real property." an important role in this fifth requirement.

"Qualified real property" is defined as real property that (a) passes from the decedent to a "qualified heir"; ${ }^{68}$ (b) was being used, as of the decedent's date of death, for a "qualified use" by the decedent or a "member of the family" of the decedent; ${ }^{69}$ and (c) together with other real or personal property being so used, comprises a certain percentage of the adjusted value of the decedent's gross estate. ${ }^{70}$ Each of those requirements will be examined in detail. They are multifaceted, complex and intertwined with the statutory definition of family under $\S 2032 \mathrm{~A}$.

\section{Passing From Decedent to Qualified Heir}

As a threshold matter, to be eligible for the special valuation rules of $\S 2032 \mathrm{~A}$, property must be acquired from or pass from the decedent to his or her "qualified heir."71 A qualified heir is defined as a "member of the decedent's family."' 2 For purposes of $\S 2032 \mathrm{~A}$, a taxpayer-decedent's "family" consists of (A) any of the taxpayer's ancestors; ${ }^{73}$ (B) the taxpayer's spouse $;^{74}(\mathrm{C})$ any lineal descendant of the taxpayer; ${ }^{75}(\mathrm{D})$ a lineal descendant of the taxpayer's spouse; ${ }^{76}(\mathrm{E})$ any descendant of the taxpayer's parents (i.e., a taxpayer's siblings, nieces and nephews, etc.); and (F) the spouse of any lineal descendant of the taxpayer, the taxpayer's spouse or any descendant of

66. Id. $\S 2032 \mathrm{~A}(\mathrm{a})(\mathrm{l})(\mathrm{B})$, (d)(2). The agrecment provides that the qualified heir will be liable for an additional tax in the event that the property is disposed of or ceases to be used for its "qualified use" within ten years of the decedent's death. Id. $\$ 2032$ A(c)(5) (liability for tax). A property's "qualified use" is its use as a farm for farming purposes or use in a trade or business other than the trade or business of farming. $I d . \S 2032 \mathrm{~A}(\mathrm{~b})(2)$.

67. Id. $\$ 2032 \mathrm{~A}(\mathrm{a})$.

68. Id. $\$ 2032 \mathrm{~A}(\mathrm{c})(7)(\mathrm{C})$ (definition of eligible qualified heir).

69. $I d . \$ 2032 \mathrm{~A}(\mathrm{~b})(1)$

70. $I d . \S 2032 \mathrm{~A}(\mathrm{~b})(1)(\mathrm{A}) ;(\mathrm{B})$.

71. Id. \& 2032A(b)(1).

72. Id. $\$ 2032 \mathrm{~A}(\mathrm{e})(2)$.

73. Id. $\$ 2032 \mathrm{~A}(\mathrm{e})(2)(\mathrm{A})$.

74. $\quad$ ld. $\S 2032 \mathrm{~A}(\mathrm{e})(2)(\mathrm{B})$.

75. ld. $\S 2032 \mathrm{~A}(\mathrm{e})(2)(\mathrm{C})$.

76. Id. 
the taxpayer's parents. ${ }^{77}$ To illustrate, consider again the family of hypothetical taxpayer Dora Ewing.

Hypothetical 3. Assume that Dora Ewing devises Blackacre, real property located in the United States, to any one of the individuals shown in Figure A.

Members of Dora Ewing's family, as defined by $\S 2032 \mathrm{~A}(\mathrm{e})(2)$, include her ancestors (her grandmother, Sarah Mannering; and her father, William Ewing); ${ }^{78}$ her spouse (Roland Lucas), ${ }^{79}$ her lineal descendants (her son, William Lucas; her daughter, Nell Lucas; her grandson, Robert Lucas and her granddaughter, Helen Lucas); ${ }^{80}$ her stepson, Roger Lucas; 'the lineal descendants of her parents (her parents as well as her brother, James Ewing; her nephew, John Ewing); ${ }^{81}$ and the spouses of any lineal descendant of Dora Ewing, of Roland Lucas or of her parents (her daughter-in-law, Gloe Cox; her grandson-in-law, Homer Morrison; her stepson's wife, Abby Gale; her sisterin-law, Mary Mack; and her nephew's wife, Raymona Weyand) ${ }^{82}$ In fact, all persons shown in Figure A, except for Jeremiah Lucas and Ellen Gray, the parents of Roland Lucas ${ }^{83}$ and Alsiness White, the second spouse of Ellen Gray, ${ }^{84}$ are "members of the family" of Dora Ewing within the meaning of $\S 2032 \mathrm{~A}^{85}$ Therefore, when Dora Ewing devises Blackacre to any of the individuals shown in Figure A other than Jeremiah Lucas and Ellen Gray, the parents of Roland Lucas, or Alsiness White, the second spouse of Ellen Gray, the property passes to a "qualified heir" within the meaning of $\S 2032 \mathrm{~A}^{86}$ and the first requirement of the definition of qualified real property is satisfied.

\section{3. "Qualified Use"}

In addition to the requirement that property pass to a qualified heir, the second prong of the test for "qualified real property" is that on the date of the decedent's death, the property is being used for a "qualified use" by the

77. $I d . \$ 2032 \mathrm{~A}(\mathrm{e})(2)(\mathrm{D})$.

78. $\quad$ ld. $\$ 2032 \mathrm{~A}(\mathrm{e})(2)(\mathrm{A})$.

79. Id. $\S 2032 \mathrm{~A}(\mathrm{e})(2)(\mathrm{B})$.

80. Id. $\$ 2032 \mathrm{~A}(\mathrm{e})(2)(\mathrm{C})$. William Lucas is a lineal descendant of his mother, Dora Ewing.

81. Id. $\$ 2032 \mathrm{~A}(\mathrm{e})(2)(\mathrm{C})$. James Ewing is a lineal descendant of Dora Ewing's father, William Ewing.

82. Id. \& 2032A(e)(2)(D).

83. $I d$,

84. Id.

85. Id. $\S 2032 \mathrm{~A}(\mathrm{e})(2)$

86. Id. $\$ 2032 \mathrm{~A}(\mathrm{~b})(1),(\mathrm{e})(2)$. 
decedent or a member of the decedent's family. ${ }^{87}$ A qualified use is "use as a farm for farming purposes" or "use in a trade or business other than the trade or business of farming."

Hypothetical 4. Assume that four years before her death, Dora Ewing inherits Greenacre from her father, William Ewing. Greenacre is real property located in the United States that is used in a family-owned business operated by Dora Ewing. At her death, Dora Ewing bequeaths to her daughter, Nell Lucas, her interest in the family-owned business. Assume that Dora Ewing's executor elects to have $\S 2032 \mathrm{~A}$ apply to the estate and files the necessary recapture agreement.

In Hypothetical 4, all the relevant criteria appear to be met. ${ }^{89}$ First, Dora Ewing is a citizen and resident of the United States. ${ }^{90}$ Second, Greenacre is located in the United States. Third, the facts provide that the executor affirmatively elects to have $\S 2032 \mathrm{~A}$ apply to the estate. Fourth, the executor files the necessary recapture agreement. Fifth, Greenacre passes to Nell Lucas, a qualified heir of Dora Ewing, ${ }^{91}$ and it is used in a trade or business, making it "qualified real property."

\section{Percentage Requirements}

In order to be eligible for the special valuation rules of $\S 2032 \mathrm{~A}$, the property not only must be used in a "qualified" way by the decedent or members of her "family," but the property also must comprise a certain percentage of the decedent's gross estate. Specifically, $50 \%$ or more of the adjusted value of the decedent's gross estate must consist of the value of real or personal property which was being used and which was acquired from or passes from the decedent to a qualified heir of the decedent, ${ }^{92}$ In other words, at least one-half of the adjusted value of the decedent's gross estate must be comprised of property eligible for valuation under $\S 2032 \mathrm{~A}$.

87. Id. $\S 2032 \mathrm{~A}(\mathrm{~b})(1)$.

88. Id. $\$ 2032 \mathrm{~A}(\mathrm{~b})(2)$. Section $2032 \mathrm{~A}$ goes on, however, to provide that use merely on the date of the decedent's death is not enough. $I d . \$ 2032 \mathrm{~A}(\mathrm{~b})(1)(\mathrm{A})$-(C). Additional use tests must be satisfied. $l d$.

89. This example assumes, among other facts, that the $50 \%$ threshold of $\$ 2032 \mathrm{~A}(\mathrm{~b})(1)(\mathrm{A})$ and the $25 \%$ threshold of $\S 2032 \mathrm{~A}(\mathrm{~b})(\mathrm{l})(\mathrm{B})$ are met.

90. Id. $\S 2032 \mathrm{~A}(\mathrm{a})(1)(\mathrm{A})$. See supra note 64 and accompanying text.

91. I.R.C. $\$ 2032 \mathrm{~A}(\mathrm{e})(2)(\mathrm{C})$ (lineal descendants are "members of the family").

92. Id. $\$ 2032 \mathrm{~A}(\mathrm{~b})(\mathrm{I})(\mathrm{A})$. The $50 \%$ test may be satisfied by an aggregate of farm property and other property used in a trade or business. Rev. Rul, 85 -168, 1985-2 C.B. 197; Estate of Geiger v. Comm'r, 80 T.C. 484 (1983); STEPHENS ET AL., supra note 20, 14.04[3][b][ii]. 
In addition to the $50 \%$ threshold, there is a second percentage test. At least $25 \%$ of the adjusted value of the gross estate must consist of property which, for an aggregate period of five years or more (during the eight-year period ending on the decedent's date of death), ${ }^{93}(\mathrm{x})$ was owned by the decedent or a member of the decedent's family; ${ }^{94}(y)$ was used for a "qualified use" by the decedent or a member of the decedent's family ${ }^{95}$ and ( $\mathrm{z}$ ) with respect to which there was "material participation" by the decedent or a member of the decedent's family in the operation of the farm or other business. ${ }^{96}$ In other words, the decedent or members of his or her family must have played a "material" role in the operation of the business. ${ }^{97}$

93. I.R.C. $\$ 2032 \mathrm{~A}(\mathrm{~b})(1)(\mathrm{B})$.

94. Id. $\$ 2032 \mathrm{~A}(\mathrm{~b})(1)(\mathrm{C})(\mathrm{i})$.

95. Id.; see Heffley v. Comm'r, 884 F.2d 279 (7th Cir. 1989) (in some circumstances, cash rental is not a qualified use); Schuneman v. United States, 783 F.2d 694 (7th Cir. 1986) (lease for part of production may constitute qualified use).

96. I.R.C. $\$ 2032 \mathrm{~A}(\mathrm{~b})(1)(\mathrm{C})(\mathrm{ii})$; see also Sherrod Estate v. Comm'r, 774F.2d 1057(11 th Cir. 1985) (passive land rental is not an active business); Estate of Trueman v. United States, 6 Cl. Ct. 380 (1984) (passive land rental is not an active business); Estate of Abell v. Comm'r, 83 T.C. 696 (1984) (same); Estate of Holmes y. Comm'r, 62 T.C.M. (CCH) 839 (1991) (describing test for what constitutes "farming"); STEPHENS ET AL., supra note 20, \4.04[3][b].

For purposes of $\S 2032 \mathrm{~A}$, material participation is defined "in a manner similar to the manner used for purposes of paragraph (1) of section 1402(a) (relating to the net earnings from self-employment)." I.R.C. $\$ 2032 \mathrm{~A}(\mathrm{e})(6)$. Under $\$ 1402(\mathrm{a})(1)$, material participation has been interpreted to mean actual involvement by the owner of property. See, e.g., Treas. Reg. $\$ 1.1402$ (a)-4(b)(3)(ii) (as amended in 1980) (in the context of crop production, "[a]n arrangement will be treated as contemplating that the owner or tenant will materially participate in the 'production' of the commodities required to be produced by the other person under the arrangement if under the amangement it is understood that the owner or tenant is to engage to a material degree in the physical work related to the production of such commodities."); see also McNamara v. Comm'r, 236 F.3d 410 (8th Cir. 2000) (in farm context, taxpayer's bookkeeping, meal preparation, field work, and machinery operation constitute material participation in farming business).

With respect to material participation in the estate tax context, Treas. Reg. $\S 20.2032 \mathrm{~A}-3$ explains that " $[w]$ hether the required material participation occurs is a factual determination, and the types of activities and financial risks which support such a finding will vary with the mode of ownership of both the property itself and of any business in which it is used." Treas. Reg. $\$ 20.2032 \mathrm{~A}-3$ (a) (as amended in 1981). The Regulation gives several examples of activities that will not qualify as material participation, including "[p]assively collecting rents, salaries, draws, dividends, or other income from the farm or other business ... merely advancing capital and reviewing a crop pian or other business proposal and financial reports each season or business year." Id. In the legislative history to the provisions of $\$ 2057$, a provision analogous to $\$ 2032$, the "principal factors" in determining material participation were described as "physical work and participation in management decisions." H.R.REP. No. 105-200, at 399 (1997) (Conf. Rep.) (statement of managers); see also Estate of Heffley v. Comm'r, 884 F.2d 279 (7th Cir. 1989) (court finding that material participation not met); Mangels v. United States, 828 F.2d 1324 (8th Cir. 1987) (court finding that material participation test was met); Estate of Sherrod, 82 T.C. 523 (1984), rev'd on other grounds, 774 F.2d 1057 (11th Cir. 1985), cert. denied, 479 U.S. 814 (1986) (court finding that material participation test was met).

97. As with the special valuation rules of $\S 2032 \mathrm{~A}$, the deduction rules of $\S 2057$ provide for the 
To satisfy the percentage requirements of $\$ 2032 \mathrm{~A}$, the taxpayer himself or herself need not be the one using the property. Just as $\S 2036(b)(2)$ 's definition of controlled corporation imputes asset ownership by certain family members to a taxpayer, $\$ 2032 \mathrm{~A}$ imputes asset use by certain family members to a taxpayer. Consider again the family of Dora Ewing shown in Figure A.

Hypothetical 5. Assume the same facts as in Hypothetical 4 above, except that at no time does Dora Ewing participate in the operation of the business. Her brother, James Ewing, personally operates the business. At her death, Dora Ewing bequeaths to her daughter, Nell Lucas, her interest in the family-owned business. Assume that Dora Ewing's executor elects to have $\$ 2032 \mathrm{~A}$ apply to the estate and files the necessary recapture agreement. Greenacre comprises at least $50 \%$ of Dora Exing's gross estate.

The fact in Hypothetical 5 that Dora Ewing herself never participates in any way in the operation of the business does not preclude the application of $\S 2032 \mathrm{~A}$ to her estate. ${ }^{98}$ As before, all the relevant criteria appear to be met. First, Dora Ewing is a citizen and resident of the United States. ${ }^{99}$ Second, Greenacre is located in the United States. Third, the facts provide that the executor affirmatively elects to have $\S 2032 \mathrm{~A}$ apply to the estate. Fourth, the facts provide that the executor files the necessary recapture agreement. Fifth, Greenacre is "qualified real property" because it passes to Nell Lucas, a qualified heir of Dora Ewing, ${ }^{100}$ and it is used in a trade or business. The participation of James Lucas in the family business redounds to the benefit of Dora Ewing's estate, making the property eligible for the special valuation

attribution to the decedent of ownership and use of the property by members of his or her family. Under $\S 2057$, an estate tax deduction of up to $\$ 675,000$ is available with respect to any "qualified family-owned business interest" owned by a decedent. I.R.C. $\$ 2057$ (a)(1). Because this rule applies only with respect to decedents dying before January 1,2004, however, it is not discussed in detail here. For further analysis of the deduction under $\$ 2057$, see, for example, Martin A. Goldberg \& Robert E. Wnek, Estate Planning for the Future Reinstatement of I.R.C. $\$ 2057,18$ QUINNIPIAC PROB. L.J, 128 (2004); Dennis I. Belcher, Planning for the Section 2057 Family-Owned Business Deduction, in Estate PLANNNG IN DEPTH 403 (ALl-ABACL,E, Course of Studies Material No. SH092, 2003); Shannon E. O'Brien, Estate Tax Treatment of Family-Owned Businesses: The Evilution of Family.Owned Businesses: The Evolution of Internal Revenue Code Section 2057, 67 UMKC L. REv. 495 (1999). Note that who qualifies as a member of a particular family is a key threshold determination in the applicability of $\$ 2057$. See Rev. Rul. 81-236, 1981-2 C.B. 172 (impact of divorce on fanily relationships). Section 2057(i)(2) incorporates by reference the definition of family used in $\$ 2032 \mathrm{~A}(\mathrm{e})(2)$.

98. This example assumes, among other facts, that the $50 \%$ threshold of $\$ 2032 \mathrm{~A}(\mathrm{~b})(1)(\mathrm{A})$ and the $25 \%$ threshold of $\$ 2032 \mathrm{~A}(\mathrm{~b})(\mathrm{I})(\mathrm{B})$ are met.

99. I.R.C. $\$ 2032 \mathrm{~A}(\mathrm{a})(\mathrm{I})(\mathrm{A})$; see supra note 64 and accormpanying text.

100. I.R.C. $\$ 2032 \mathrm{~A}(\mathrm{e})(2)(\mathrm{C})$ (lineal descendants are "members of the family"). 
rule of $\S 2032 \mathrm{~A}$, because it comprises the requisite percentage of the adjusted value of Dora Ewing's gross estate. ${ }^{101}$

The estate tax law takes an expansive view of family-owned businesses by according benefits to taxpayers who themselves may not be actively involved in running the business, as long as members of their family are. By allowing the attribution of the activities (and ownership) of family members to a taxpayer, the law recognizes that family-owned businesses are different from other assets. Therefore, the definition of a decedent's "family" plays a critical role in the interpretation and application of $\S 2032 \mathrm{~A} .{ }^{102}$

\section{Payment of Taxes-I.R.C. $\S 6166$ 's Extension of Time for Payment of Estate Taxes}

\section{Generally}

The identity and activities of a taxpayer's family bear on not only what assets are included in a decedent's gross estate ${ }^{103}$ and how they are valued, ${ }^{104}$ but also when the calculated taxes must be paid. The general rule is that the executor must pay estate tax within nine months of the decedent's date of death. ${ }^{105}$ In certain limited instances, however, an executor may elect to pay the estate tax liability in as many as ten annual installments. ${ }^{106}$ This

101. I.R.C. $\$ 2032 \mathrm{~A}$ (b)(1)(A); see supra notes $92-96$ and accompanying text.

102. Section 2057 is another Code section in which the definition of family plays an important role. Section 2057 allows an estate tax deduction for certain interests in qualified family owned businesses, but is repealed for decedents dying after 2003 and before 2011. I.R.C. $\$ 2057(j)$. Under the "sunset" provisions of the Economic Growth and Tax Relief Reconciliation Act of 2001, Pub. L. No. 107-16, $\$ 901(\mathrm{a})(1), 115$ Stat. 38,150 [hereinafter EGTRRA], the deduction is scheduled to be applicable to decedents dying in 2011 and after. Section 2057 incorporates by reference $\$ 2032 \mathrm{~A}^{\prime} \mathrm{s}$ definition of qualified heir. I.R.C. $\S \S 2057(\mathrm{~b})(2)(\mathrm{B}), 2032 \mathrm{~A}(\mathrm{e})(9)$. For these reasons, this Article does not address $\S 2057$ in detail. Note, however, that estates that qualify for the special valuation rules of $\$ 2032 \mathrm{~A}$ often seek to qualify also for the deduction under $\$ 2057$. See generally ROBERT M. BELLATTI, EsTATE PlanNing for Farms and OTher QUALIFIEd FamLí OWNED Businesses (1998). For a discussion of planning opportunities for $\$ 2057$ in 2011 and after, see Goldberg \& Wnek, supra note 97.

103. See generally supra Part LA.1,2.

104. See generally supra Part L.B.

105. Section 2001(a) imposes a tax on the transfer of the taxable estate of every citizen or resident of the United States. I.R.C. $\$ 2001$. Under $\$ 6075(a)$, the due date is the nine month anniversary of the decedent's death, unless the Service has granted an extension of time to file. See also id. $\$ 6151(\mathrm{a})$ ("W]hen a return of tax is required ... the person required to make such retum shall, without assessment or notice and demand from the Secretary, pay such tax to the internal revenue officer with whom the return is filed, and shall pay such tax at the time and place fixed for filing the return . . ."); Treas. Reg. $\$ 20.6075-1$ (as amended in 2001) (same).

106. See I.R.C. $\$ 6166(a)(1)-(3)$. For a description of the overlap between the 10-year extension of 
installment option is available under $\$ 6166$ to those estates in which the value of an "interest in a closely held business" that is included in the decedent's gross estate exceeds $35 \%$ of the adjusted gross estate. ${ }^{107}$ At first reading, this rule seems to be purely arithmetic. However, whether a particular interest is one in a "closely held business" for $\S 6166$ purposes is a complex determination that again depends on the definition of family. Perhaps not surprisingly at this point in the analysis, $\$ 6166$ 's definition is different from each of the previous definitions used in $\S 2036$ (a) and $\S 2032 \mathrm{~A} .{ }^{108}$

For purposes of $\S 6166$, an "interest" in a closely held business is a proprietorship interest, a partnership interest or stock in a corporation, ${ }^{109}$ as long as the proprietorship, partnership or corporation is carrying on a trade or business. " ${ }^{\text {A }}$ A partnership or corporation is "closely held" for purposes of $\S 6166$ if either (a) the decedent's gross estate includes $20 \%$ or more of the partnership's total capital interests (in the case of a partnership interest) ${ }^{113}$ or the value of the voting stock of the corporation (in the case of stock) ${ }^{i 2}$ or (b) the partnership or corporation has 45 or fewer partners or shareholders. ${ }^{133}$ To illustrate, consider another hypothetical.

Hypothetical 6. Assume that Dora Ewing dies with a gross estate valued for estate tax purposes at $\$ 10,000,000 .{ }^{14}$ Further assume that the only assets of her estate are

time to pay under $\S 6166(a)(1)$ and the 5-year deferral period under $\S 6166(a)(3)$, see supra note 13 .

107. I.R.C. $\$ 6166(a)(1)$.

108. $1 d . \$ 6166(\mathrm{~b})(1)(\mathrm{A}) \cdot(\mathrm{C})$.

109. Id.

110. Id. $\$ 6166(\mathrm{~b})(\mathrm{l})(\mathrm{A})$. Presumably passive investing as a proprietorship would not qualify as a trade or business. See Rev. Rul, 61-55, 1961-1 C.B. 713 (ownership of oil and gas royalty interests alone is not a trade or business for purposes of LR.C. $\$ 6166$ ); see also Rev. Rul. 75-365, 1975-2 C.B. 471 (" $\$ 166$ was intended to apply only with regard to a business such as a manufacturing, mercantile, or service enterprise, as distinguished from management of investment assets."); Rev. Rul. 75-367, 1975-2 C.B. 472 ["[LR.C. \& 6166] was not intended to protect continued managernent of income producing properties . . . except where they formed a part of an active enterprise producing business income rather than income solely from the ownership of property."); I.R.S. Tech. Adv. Mem. 84-48-006 (Aug. 20, 1984) (To qualify for $\$ 6166$ treatment, interest "must be an interest in an active trade or business. The level of activity is the factor that distinguishes an 'active business' from the mere passive ownership of income producing assets."). See generally Jonathan E. Gopman \& Paul B. McCawley, Estate Tax Payments and Liabilities, 832 TAX MGMT, (BNA), at A-7 n.60 (2003) (on active business vs. investment purposes).

111. L.R.C. $\$ 6166(\mathrm{~b})(1)(\mathrm{B})(\mathrm{i})$.

112. Id. $\$ 6166(\mathrm{~b})(1)(\mathrm{C})(\mathrm{i})$.

113. Id. $\$ 6166(\mathrm{~b})(1)(\mathrm{B})(\mathrm{ii}),(\mathrm{C})(\mathrm{i})$.

114. Property is valued for estate tax purposes at its fair market value as of the decedent's date of death, or as of the alternate valuation date, if applicable. Treas. Reg. $\$ 20.2031-1$ (b) (as amended in 1965). The rules applicable to the selection of the alternate valuation date bave been changed by final regulations issued on January 4,2005. See T.D. 9172, 2005-6 1.R.B. 468 (amending Treas. Reg. $\$ 20.2032-1(\mathrm{~b})$ ). The regulations provide that altemate valuation is available only if such an election will decrease both the size 
$\$ 6,000,000$ in cash and $\$ 4,000,000$ of stock of Company $Y$, and that at the time of her death, Dora Ewing owned $100 \%$ of Company Y's outstanding stock.

In order to qualify for the extension of time to pay estate tax under $\S 6166(a)$, Dora Ewing's executor must make three showings: first that Dora Ewing owned an "interest" in Company $\mathrm{Y} ;{ }^{: 15}$ second that Company $\mathrm{Y}$ is "closely held" with respect to her; ${ }^{116}$ and third that the value of Dora Ewing's interest in Company $Y$ exceeds $35 \%$ of the adjusted gross estate. ${ }^{117}$ All showings are made here. Dora Ewing owned Company Y stock, and stock is a business "interest." 1. Second, Company Y is "closely held" because Dora Ewing owned more than $20 \%$ of Company Y's voting stock (in fact, she owned $100 \%$ ), and because Company $Y$ had 45 or fewer shareholders (in fact, Dora Ewing was the sole shareholder) ${ }^{119}$ Third, the value of Dora Ewing's interest in Company $\mathrm{Y}(\$ 4,000,000)$ exceeds $35 \%$ of her gross estate (in this case it is $40 \%$ of her entire gross estate). ${ }^{120}$ Dora Ewing's estate therefore should be eligible for the extension of time for payment of estate tax under $\S 6166(\mathrm{a}){ }^{121}$

\section{Attribution Rules}

In contrast to the facts of Hypothetical 6 above, consider a scenario in which Dora Ewing's individual ownership does not rise to the requisite level. Her estate nevertheless may be able to qualify for the extension of time to pay estate taxes through possible application of any one of three rules that attribute others' ownership interests to Dora Ewing. First, stock or partnership interests held jointly ${ }^{122}$ or as community property with a surviving spouse will

of the gross estate and the sum of the estate and generation-skipping transfer tax liability payable by reason of property inciudible in the decedent's gross estate. Treas. Reg. $\S 20.2032-1$ (b) (as amended in 1965).

115. I.R.C. $\$ 6166(\mathrm{a})(1)$.

116. Id.

117. Id.

118. Id. $\$ 6166(\mathrm{~b})(1)(\mathrm{A})-(\mathrm{C})$.

119. Id. $\$ 6166(\mathrm{~b})(\mathrm{i})(\mathrm{C})$. It would be sufficient for the executor to satisfy either the voting percentage or the shareholder test in order for Company $\mathrm{Y}$ to qualify as a closely held business with respect to the decedent.

120. The gross estate is $\$ 10,000,000-\$ 6,000,000$ in cash and $\$ 4,000,000$ in Company Y stock.

121. I.R.C. $\$ 6166(\mathrm{a})(1)$.

122. For purposes of $\S 6166$ (b)(2)(B)(ii), joint ownership includes joint tenancy, tenancy by the entirety, or tenancy in common. Generally speaking, joint tenancy is "tenancy with two or more coowners who take identical interests simultaneously by the same instrument and with the same right of possession." BLACK'S LAW DICTKONARY 1505 (7th ed. 1999). Tenancy by the entirety typically is "a form of joint tenancy. It resembles joint tenancy in that upon the death of either husband or wife the survivor automatically acquires title to the share of the deceased spouse. Like a joint tenancy, also, it is necessary 
be treated as owned by a single taxpayer. ${ }^{123}$ Second, a shareholder, partner or beneficiary of a trust is deemed to own proportionately any property owned directly or indirectly by or for any corporation, partnership or trust. ${ }^{124}$ Third, a decedent is deemed to own all partnership interests and stock owned by any "member" of his or her "family," as defined in $\$ 267(\mathrm{c})(4) .{ }^{125}$ In other words, a decedent is deemed to own all partnership interests and stock owned by his or her siblings, ${ }^{126}$ spouse, ancestors and lineal descendants. ${ }^{127}$ As a practical matter, these three attribution rules mean that for purposes of the limitation on the number of partners or shareholders of a closely held business, the decedent and members of his or her family are treated as one taxpayer. ${ }^{128}$

To illustrate the application of the attribution rules; consider the following hypothetical.

Hypothetical 7. Assume the same facts as in Hypothetical 6 above, except that Dora Ewing is one of 50 shareholders of Company Y. Each shareholder, including Dora

for the creation of a tenancy by the entireties that the husband and wife acquire title by the same deed or will." Id. at 1506 (quoting RoBERT KRATOVIL, REAL. EsTATE LAW 198 (6th ed. 1974)). Finally, tenancy in common is "tenancy by two or more persons, in equal or unequal undivided shares, each person having an equal right to possess the whole property but no right of survivorship." Id.

123. I.R.C. $\$ 6166(\mathrm{~b})(2)(\mathrm{B})(\mathrm{i})$, (ii).

124. Id. $\$ 6166(\mathrm{~b})(2)(\mathrm{C})$. For purposes of $\$ 6166(\mathrm{~b})(2)(\mathrm{C})$, a person is a "beneficiary" of a trust only to the extent that such person has a "present interest" in the trust. Presumably a "present interest" would be interpreted to mean a present right to receive income or principal from the trust. Cf. id. $\$ 2503$ (b) (transfers of present interests may qualify for the gift tax annual exchusion); Treas. Reg. \$25.2503-3(b) (as amended in 1983) ("An unrestricted right to the immediate use, possession, or enjoyment of property or the income from property (such as a life estate or term certain) is a present interest in property."). In the generation-skipping transfer tax context, a person has an "interest" in a trust if he or she (i) has a present right to receive trust income or principal; (ii) is a permissible current recipient of trust principal or income and is not described in section 2055(a) (a transfer for public, charitable or religious use); or (iii) a transfer for public, charitable or religious use if the trust is a charitable remainder annuity trust, a charitable remainder unitrust or a pooled income fund Treas. Reg. $\$ 26.2612-1$ (e)(1) (as amended in 2005); cf. TENN. CODE ANN. $\S 67-8-101$ (2004) ("Where a donor transfers an unqualified and unrestricted gift to a person in trust, such transfer is a gift of a present interest where the trust instrument provides that the beneficiary has the power to demand immediate possession and enjoyment of such gift in the calendar year in which it is given."); WIS. STAT. $\$ 700.03$ (2004) ("Interests in property are classified as to the time of enjoyment as: (1) [a] present interest, which entitles the owner to the present possession or enjoyment of the benefits of property; or (2) [a] future interest, which does not entitle the owner to possession or enjoyment of the benefits of property until a future time.").

125. I.R.C. $\S 6166(\mathrm{~b})(2)(\mathrm{D})$.

126. To qualify as a "sibling" of a taxpayer, such person need have only one parent in common with the taxpayer. In other words, it is irrelevant whether the sibling is "by the whole or half blood." Id. $\S 267(\mathrm{c})(4)$.

127. Id. The ancestors or siblings of a taxpayer's spouse are not included within the definition of family for purposes of $\$ 267(\mathrm{c})(4)$.

128. Id. $\S 6166(\mathrm{~b})(2)(\mathrm{B})-(\mathrm{D})$. 
Ewing, owns 1,000 shares valued at $\$ 4,000$ per share $\left(\$ 4,000,000\right.$ in aggregate). ${ }^{129}$ The corporation has no other voting stock and all stock has the same voting rights. Of the 49 shareholders other than Dora Ewing, one is her father, William Ewing; one is her husband, Roland Lucas; one is her brother, James Ewing; one is her son, William Lucas; and one is her daughter, Nell Lucas. The other 44 shareholders are not related to Dora Ewing in any way.

On the question of whether Company $\mathrm{Y}$ is a closely held corporation with respect to Dora Ewing, she herself owns only two percent (or 1,000 out of $50,000)$ of the corporation's voting shares, ${ }^{130}$ making Company Y not closely held on that basis alone. ${ }^{131}$ Nevertheless Dora Ewing's interest in Company $Y$ may qualify as an "interest in a closely held business" if Company $Y$ has 45 or fewer shareholders. ${ }^{132}$ At first glance, this seems impossible because Hypothetical 7 states that Company $Y$ had 50 shareholders. Recall however, that under $\S 6166(\mathrm{~b})(2)(\mathrm{D})$, stock held by a decedent-taxpayer "or by any member of his family within the meaning of section $267(\mathrm{c})(4))$ shall be treated as owned by the decedent." A taxpayer's "family" is defined in $§ 267(\mathrm{c})(4)$ as siblings, spouse, ancestors and lineal descendants. ${ }^{134}$ Thus Dora Ewing is deemed to own the shares held by her brother, James Ewing; her husband, Roland Lucas; her father, William Ewing; her son, William Lucas; and her daughter, Nell Lucas, all of whom are members of her family for purposes of $\S 6166 .^{135}$ Through the application of these attribution rules, Company $Y$ is deemed to have 45 total shareholders (i.e., Dora Ewing and the 44 individuals who are not related to her in any way). Company $Y$ therefore is a closely held business with respect to Dora Ewing within the meaning of

129. For purposes of this illustration, assume that no valuation discounts are applicable to the shares owned by Dora Ewing or any other shareholder of Company Y. For a general discussion of valuation discounts in the estate tax context, see 15 JACOB MERTENS LAW OF FEDERAL INCOME TAXATroN $\$$ 59:14 (Christina F. McCann ed., 2005) (valuation for federal estate tax purposes); Wendy C. Gerzog, Actuarial Tables Versus Factually Based Estate Tax Valuation: Ithaca Trust Revisited, 38 REAL Prop. PROB. \& TR. J. 745 (2004); Joshua S. Rubenstein, Valuation, Taxation \& Planning Techniques for Sophisticated Estates: Recent Developments, in VALUATION, TAXATION \& PLANNDG TECHNIQUES FOR SOPHISTICATED Estates 2003, at 7 (PLI Tax Law \& Est. Plan. Practice Course, Handbook Series No. 322, 2003).

130. The shares would most likely be included in Dora Ewing's estate under $\$ 2033$ (property in which the decedent had an interest). The attribution rules of $\$ 6166(b)(2)$ apply only for purposes of the definition of a closely held business interest, not to estate tax inclusion itself. I.R.C. $\$ 6166(b)(2)$.

131. See $i d$. $\$ 6166(b)(1)(C)(i)$ (decedent's stock ownership of a corporation will be a closely held business interest for purposes of $\$ 6166(a)(1)$ if decedent's gross estate includes twenty percent or more of the value of the voting stock of the corporation).

132. $l d . \$ 6166(\mathrm{~b})(\mathrm{l})(\mathrm{C})(\mathrm{ii})$.

133. Id. $\$ 6166(b)(2)(D)$.

134. Id. $\S 267(\mathrm{c})(4)$.

135. Id. $\$ 6166(\mathrm{~b})(2)(\mathrm{D})$. 
$\S 6166(\mathrm{~b})(1)(\mathrm{C})(\mathrm{ii}) .{ }^{136}$ That fact, combined with the fact that the value of her interest in Company Y exceeds $35 \%$ percent of her gross estate, means that Dora Ewing's estate will be eligible for the deferred payment provisions of $\S 6166 .^{137}$

\section{A Spectrum of Definitions}

Each of the Code sections described in this Part defines "family" (or "related" persons) differently. Putting aside the potential inclusion of corporations and employees in the definition of "related or subordinate" parties under $\S 672(\mathrm{c}),{ }^{138}$ made applicable to $\S 2036(\mathrm{a})(2)$, the Code sections could be arranged on a definitional spectrum with restrictive and expansive definitions at opposite ends. At the restrictive end of the spectrum would be $\S 2036$ 's inclusion rule for retained interests in "controlled corporations." 339

136. Id. $\$ 6166(\mathrm{~b})(\mathrm{I})(\mathrm{C})(\mathrm{ii})$.

137. Id. $\$ 6166(a)$. Presumably the attribution rules can apply alone or in combination. Consider, for example, another hypothetical:

Hypothetical 7/2. Assume the same facts as in Hypothetical 7, above, except that instead of five

of Dora Ewing's family members holding shares of Company $Y$, each of these family members was

the sole owner of a corporation that in turn owned 1,000 shares of Company $Y$ stock.

In this example, Company $Y$ again is not a "closely held business" interest with respect to Dora Ewing under the percentage ownership test because only two percent (or 1,000 out of 50,000 ) of the corporation's voting shares is included in Dora Ewing's gross estate. See id. \$ 6166(b)(1)(C)(1) (decedent's stock ownership of a corporation will be a closely held business interest for purposes of $\$ 6166(a)(1)$ if decedent's gross estate includes twenty percent or more of the value of the voting stock of the corporation). The shares would most likely be included in Dora Ewing's estate under $§ 2033$ (property in which the decedent had an interest). The attribution rules of $\$ 6166(\mathrm{~b})(2)$ apply only for purposes of the definition of a closely held business interest, not to estate tax inclusion itself. See id. \$ 6166(b)(2). Under the shareholder test, however, Company $Y$ will constitute a controlled corporation with respect to Dora Ewing by virtue of a double application of the attribution rules. See id. $\S 6166(\mathrm{~b})(1)(\mathrm{C})(\mathrm{ii}),(\mathrm{b})(2)(\mathrm{D})$.

To explain, $\S 6166(\mathrm{~b})(2)(\mathrm{C})$ provides that a corporation's holdings will be deemed to be owned proportionately by its shateholders. $I d$. $\$ 6166(\mathrm{~b})(2)(\mathrm{C})$. Hypothetical $7 \frac{1}{2}$ provides that each of William Ewing, Roland Lucas, James Ewing, William Lucas, and Nell Lucas is the sole shareholder of a company that owns 1,000 shares of Company $Y$ stock. For purposes of $\$ 6166$, then, each of those persons is deemed to own 1,000 shares directly. Id. $\S 6166(\mathrm{~b})(2)(\mathrm{C})$. Furthermore, in determining whether Company $Y$ has 45 or fewer shareholders, Dora Ewing will be deemed to own the shares of Company $Y$ that her father, spouse, brother, and children own. See id, $\$ 6166(b)(2)(D)$. Thus, as before, Company $Y$ will be deemed to have 45 total shareholders (i.e., Dora Ewing and the 44 individuals who are not related to her in any way). Company $\mathrm{Y}$ meets the definition of a closely held business within the meaning of $\S 6166(\mathrm{~b})(1)(C)(\mathrm{ii})$, and because the value of Dora Ewing's interest in Company $Y$ exceeds $35 \%$ of her gross estate, her estate should be eligible for the deferred payment provisions of $\$ 6166$. Id. $\$ 6166(\mathrm{a})$.

138. Id. \$ 672(c)(2); see supra notes $42-43$.

139. Under $\$ 2036(a)$ (1), the value of a decedent's gross estate includes the value of "all property to the extent of any interest therein of which the decedent has at any time made a transfer . . by trust or otherwise, under which he has retained ... the possession or enjoyment of, or the right to the income from, 
Section 2036(b)(2)'s reference to $\$ 318$ attributes to a taxpayer the ownership of his or her spouse, children, grandchildren and parents. ${ }^{140}$ At the broad end of the spectrum (again, ignoring corporations and employees) would be $\S 2032 \mathrm{~A}$ and its vision of family as including stepchildren and various relations by marriage. ${ }^{141}$ Somewhere in between would be $\S 6166^{142}$ and $\S 2036(a)(2),{ }^{143}$ identical in all important respects except for the latter's inclusion of certain corporations and family members in the definition of family.

The $\S 2036(\mathrm{a})(2)$ rule, read together with $\S 672(\mathrm{c})$, is unique in that it moves the definition of "related" persons beyond family relationships defined by blood or marriage. In that sense, it seems to be a broad-reaching and comprehensive definition of family, although notably stepchildren and stepgrandchildren, nieces and nephews and spouses of children ${ }^{144}$ are not otherwise members of the family, absent an additional employment relationship. ${ }^{145}$ The reasons for the differences in the definitions of "family" and "related" persons will be explored in Part II.

\section{Family Heritage: The Origins of the Estate Tax Constructions OF FAMILY}

The Code sections described in Part I were adopted at different times and for different purposes. Section 2036, for example, is a rule of estate tax inclusion that applies when a decedent maintains too much control over transferred property. ${ }^{146}$ Section $2032 \mathrm{~A}$, in contrast, is concerned with the valuation of property that is already included in the gross estate and aims to reduce estate tax so that a farm or other business will be more likely to stay

the property." I.R.C. $\$ 2036(a)(1)$; see supra note 18 and accompanying text.

140. 1.R.C. $\$ 318(a)(1)$; see also supra notes $25-28$ and accompanying text.

141. Under $\S 2032 \mathrm{~A}$, certain real property may be valued for estate tax purposes at its value for use as a farm for farming purposes or its use in a trade or business other than the trade or business of farming. I.R.C. $\$ 2032 \mathrm{~A}(\mathrm{a})(1)$; see supra Part I.B. 1 and accompanying text.

142. Under $\$ 6166$, an executor may elect to pay estate tax liability in installments. I.R.C. $\S 6166(\mathrm{a})(1)-(3) ;$ see supra Part LC.1.

143. Section 2036(a)(2) includes in a decedent's gross estate the value of all property to the extent that the decedent retains the right to designate the persons who benefit from the transferred property. I.R.C. $\S 2036(a)(2)$; see supra Part LA.2.

144. Cf. I.R.C. \& 2036(a)(2) (stepchildren and step-grandchildren, nieces and nephews and spouses of children are not defined as members of the family).

145. The differences among the relevant Code sections are summarized in the Appendix.

146. See infra Part II.A. 
in a family. ${ }^{147}$ Finally $\S 6166$ applies after the value of a gross estate has been determined, and provides certain taxpayers with an extension of time to pay estate taxes. ${ }^{148}$ In enacting (and revising) each of these provisions separately over a period of several years, it does not appear that lawmakers took the extant sections into account. For that reason, no one definition of family applies universally for all estate tax purposes.

\section{A. Estate Tax Inclusion: I.R.C. $\$ 2036$}

The 1976 enactment of $\$ 2036(b)^{249}$ seems to have been a direct response to strategic activity by taxpayers, and in particular, estate planning techniques that were touted as "the "ultimate' in estate planning." " The techniques typically were straight-forward transfers of shares to a trust, for example, without relinquishment of voting rights, which some contemporary commentators suggested rendered the transfer eligible for a gift tax valuation discount (for the retained voting right) without being later subject to estate taxation (because the transferor no longer owned the shares). ${ }^{i s}$ In fact, $\S 2036$ (b) frequently is called the "anti-Byrum" provision, ${ }^{152}$ after the 1972 case in which the government unsuccessfully asserted estate tax inclusion caused by a taxpayer's retention of voting rights with respect to shares transferred to a trust. ${ }^{153}$ In enacting $\S 2036(\mathrm{~b})$, lawmakers took the view that voting rights were the essence of stock ownership and explained that, "[v]oting rights are so significant with respect to corporate stock that the

147. See infra Part II.B.

148. See infra Part II.C.

149. Tax Reform Act of 1976 , Pub. L. No. $94-455,90$ Stat. 1520 (codified as amended in scattered sections of the I.R.C.).

150. H.R. REP. No. 94-1380, at 799 n.3 (1976). The House Report referred to published articles describing aggressive estate planning techniques: "One commeatator has suggested that "[t]he "ultimate" in estate planning for most controlling stockholders of closely held corporations is the avoidance of a Federal estate tax on corporate voting shares that they have transferred to a trust in which they have reserved the uninterrupted right to continue voting the shares." Id. (quoting Stanley Pressment, Effect of Tax Court's Gilman Decision on Estate Planning for the Close Corporation, 44 J. TAX'N 160 (1976)).

151. Id. ("Mr. Pressment] further suggests that the value of the gift might be reduced by the value attributable to the retained voting rights. If this is done, the value attributed to voting rights would not be subject either to gift tax at the time of the gift or ... the estate tax upon the death of the donor.").

152. STEPHENS ET AL., supra note $20,94.08[6][d]$.

153. United States v. Byrum, 408 U.S. 125 (1972). For a general discussion of the Byrum case, see Mitchell M. Gans \& Jonathan G. Blattmachr, Strangi: A Critical Analysis and Planning Suggestions, 100 TAX NOTES 1153, 1154, 1156-59 (2003); Brant J.. Hellwig, Revisiting Byrum, 23 VA. TAX REV. 275 (2003); Jensen, supra note 19 , at 221 n. 156. 
retention of voting rights by a donor should be treated as the retention of the enjoyment of the stock for estate tax purposes." 154

Notwithstanding legislators' clear views on the property-like nature of voting rights, the adopted aggregation rules of $\S 2036$ (b) (made applicable to the estate tax inclusion rule of $\$ 2036(a)(1)$ ) do not necessarily accomplish legislative intent. It is not clear from the legislative history, for example, why Congress chose one set of attribution rules over another for purposes of $\S 2036(\mathrm{~b}){ }^{155}$ There is no intuitive reason that an individual's stock ownership should be aggregated with that of his or her spouse, children, grandchildren and parents, for example, but not with other family members. Indeed $\S 2036$ (b)(2)'s attribution rule is internally inconsistent insofar as Taxpayer 1's ownership is aggregated with the ownership of his or her grandchild, Taxpayer 2, for purposes of a transfer by Taxpayer 1, but the rule does not apply in reverse. For purposes of a transfer by Taxpayer 2, his or her ownership is not aggregated with that of Taxpayer 1 , the grandparent. If voting rights truly were the quintessence of property ownership, one would expect to see a bilaterally applicable rule. But $\S 2036(\mathrm{~b})(2)$ is concerned not just with ownership but also with control. The unilateral attribution of Taxpayer 1's stock ownership with Taxpayer 2's is based on the presumption that a grandparent controls his or her grandchild, but that the grandchild does not control the presumably wealthier and more powerful grandparent.

Unlike the inclusion rule of $\$ 2036(\mathrm{~b})$ which was enacted by statute, the inclusion rule of $\S 2036(\mathrm{a})(2)$ is the product of revenue rulings and court decisions. ${ }^{156}$ Indeed \$2036(a)(2) itself contains no prohibition on the removal of certain trustees by a taxpayer-transferor. ${ }^{157}$ Furthermore, while the estate tax inclusion rule is rooted in concerns about a grantor attempting to evade taxation on assets he or she still controls, it is not obvious why the class of trustees who may be appointed in a removed trustee's place should be defined by reference to the income tax provisions of $\S 672(\mathrm{c}){ }^{158}$ The Service just as easily could have defined the prohibited class by reference to another estate tax provision. Although the Service's ruling lacks direct legislative authority,

154. H.R. REP. No. 94-1380, at 65 (1976).

155. See I.R.C. $\$ 318(a)(1)(A)$.

156. See Rev. Rul. 95-58, 1995-2 C.B. 191 ; see also supra note 36 (discussing Estate of Wall and Estate of Vak).

157. See 1.R.C. $\$ 2036(a)(2)$.

158. See Rev. Rul. 95-58, 1995-2 C.B. 191. 
any interpreting court should give significant deference to the Treasury Department's revenue ruling. ${ }^{159}$

\section{B. Estate Tax Valuation: I.R.C. $\$ 2032 A$}

Unlike $\S 2036(\mathrm{a})(1)$ and (2), which are estate tax inclusion rules, $\S 2032 \mathrm{~A}$ is a valuation provision that is designed to benefit farmers and small business owners. In enacting $\S 2032 \mathrm{~A}$ in 1976 , legislators singled out these constituents for the favorable valuation rules on the ground that they were engaged in particularly desirable activities: "[I]t is inappropriate to value land on the basis of its potential 'highest and best use' especially since it is desirable to encourage the continued use of the property for farming and other small business purposes."160 In interpreting $\S 2032 \mathrm{~A}$, the Tax Court has identified the legislative intent as concern with estate tax liquidity, explaining that "[ $t$ ]he purpose of the special valuation provision is to lessen the estate tax burden and to alleviate the liquidity problems faced by the surviving family of a person who dies owning real property used as a farm or in a closely held business. The provision is intended to allow the family to continue operating the farm or other business, rather than being forced to sell the land to pay estate taxes." $16 \mathrm{I}$

The definition of family in $\S 2032$ has not been static since its enactment. As part of the Economic Recovery Tax Act of 1981, the provisions of

159. See Gans, supra note 36 , at 777-79 (indicating that the Supreme Court "likely will eventually clarify that Skidmore is the appropriate framework for analyzing the vali city of nilings," where Skidmore stands for the proposition that courts will defer to revenue rulings by the Internal Revenue Service where the agency has undertaken a thorough decision-making process, maintained its position consistently, and employed valid reasoning).

160. H.R.REP.NO. 94-1380, at 21-22 (1976); see also STAFF OF JOINT COMM. ON TAXATION, PUBL'N No. JCS-33-76, GENERAL. EXPLANATION OF THE TAX REFORM ACT OF 1976, at 537 (1976) ("Valuation on the basis of highest and best use, rather than on actual use, may result in the imposition of substantially higher estate taxes. In some cases, the greater estate tax burden makes continuation of farming, or the closely heid business activities, not feasible because the income potential from these activities is insufficient to service extended tax payments or loans obtained to pay the tax.").

161. Stoval v. Comm'r, 101 T.C. 140,146(1993); see also Zumbach et al., supra note 57, at A.I (the special valuation rules "benefit heirs who, while desiring to continue the operation of a farm or closely held business, could otherwise be required to sell such property to pay estate taxes"). In enacting a related provision, the deduction for qualified family owned business interests under $\$ 2057$, the Senate Finance Committee explained that "a reduction in estate taxes for qualified family-owned businesses will protect and preserve family farms and other family-owned enterprises, and prevent the liquidation of such enterprises in order to pay estate taxes. The Committee further believes that the protection of family enterprises will preserve jobs and strengthen the communities in which such enterprises are located." $S$. REP. No. 105-33, at 40 (1997). 
$\S 2032$ A were changed so that "members of the family" excluded lineal descendants of grandparents and included lineal descendants of the taxpayer's spouse. ${ }^{162}$ With this change, lawmakers eliminated aunts, uncles and cousins from the group of those whose use of property ${ }^{163}$ or material participation in a family business ${ }^{164}$ could inure to the benefit of a taxpayer-decedent. It appears that this substantive change was made without significant debate. In fact, the change was listed in the Joint Committee's General Explanation under the heading "Miscellaneous Technical Changes," without any explanation at all. ${ }^{165}$

The lack of meaningful legislative debate on the revisions to $\S 2032 \mathrm{~A}$ in some ways belies the importance of this Code section to larger social and political debates about the estate tax. Some politicians and most opponents of estate taxation are quick to point to the estate tax as a major impediment to the future of American farming. ${ }^{166}$ But recent changes to the law have rendered $\S 2032 \mathrm{~A}$ relatively unimportant in the estate tax debate, given the high current estate tax exemption amounts and the average value of the American farm. ${ }^{167}$ The New York Times, for example, estimates that the number of farms that are subject to estate taxation is somewhere around 300 , and fewer than 27 of those are unable pay estate taxes because of lack of

162. Economic Recovery Tax Act of 1981, Pub. L. No. 97-34, 95 Stat. 306 [hereinafter ERTA]; see H.R. REP. No. 97-215, at 252 (1981) (Conf. Rep.) (describing change without explanation).

163. I.R.C. $\$ 2032 \mathrm{~A}(\mathrm{~b})(1)$; see supra note 69 and accompanying text.

164. I.R.C. $\& 2032 \mathrm{~A}$ (b)(1)(C)(ii); see supra note 96 and accompanying text.

165. Staff of Joint Comm. on Taxation, Publ'n No. JCS-71-81, General Explanation of the Economic Recovery Tax Act of 1981, at 251-52 (1981).

166. See Estate Tax Could See Senate Floor, Despite No Concrete Compromise, 6 OMB WATCHER 15 (2005), available at http://www.ombwatch.org/Watcher/july252005.pdf.

167. See I.R.C. $\$ \S 2001,2010$ (a). Pursuant to the Economic Growth and Tax Relief Reconciliation Act of 2001 , Pub. L. No. 107-16, $\S 521,115$ Stat. 38, 71-72, the unified credit will protect $\$ 1,500,000$ of assets in $2005 ; \$ 2,000,000$ in 2006 through $2008 ; \$ 3,500,000$ in 2009 ; and $\$ 1,000,000$ in assets in years after 2010. Id. For a general discussion of EGGTRA, see Jonathan G. Blattmachr \& Lauren X. Detzel, Estate Planning Changes in the 2001 Tax Act-More Than You Can Count, 95 J. TAX'N 74 (2001) (overview of EGTRRA's changes to the law); Jonathan G. Blattmachr \& Mitchell M. Gans, Wealth Transfer Tax Repeal: Some Thoughts on Policy and Planning, 90 TAX Notes 393, 396 (2001) (discussion of estate and gift tax planning opportunities presented by EGTRRA). 
liquidity. ${ }^{168}$ The ambiguities in $\S 2032 \mathrm{~A}$ 's definition of family, then, may be of practical import to a relatively small number of taxpayers.

\section{Estate Tax Payment: I.R.C. $\$ 6166$}

In 1958, Congress first enacted the extension of time to pay estate taxes under $\S 6166$ to provide some relief to estates substantially comprised of closely held business interests. ${ }^{169}$ The purpose of this legislation, according to contemporary statements on the Senate floor, was "to prevent the break up of small businesses once they are established and to prevent their consolidation into larger businesses. [The ten-year extension of time to pay taxes] should make it unnecessary to sell a decedent's business in order to finance his estate."170 Tax relief was viewed as a fulfillment of a bipartisan agreement "to study and solve the handicaps of new and small business." By placing less tax burden on owners of small businesses, lawmakers reasoned, the new law would be "profitable to our country because this help to small business is truly an investment in our economy-strengthening our communities in peace-improving our ability to meet the demands of defense." H72 Historically, small businesses had "not been sharing in the general prosperity of the country," according a Senate Report on the "Tax Problems of Small Business." ${ }^{173}$ Continued ownership of small businesses thus was articulated as one of the preconditions for overall national prosperity.

168. David Cay Johnston, Few Wealthy Farmers Owe Estate Taxes, Report Says, N.Y. TMMES, July 10,2005 , at A-21. The Times reports that the Congressional Budget Office

hinted that the actual number lof farmers lacking liquidity to pay taxes] might be zero. The

[Congressional Budget Office] study examined how much in cash, stocks and bonds these farmers left to pay estate taxes, but the report noted that no data existed on how much life insurance the farmers had put into trusts. Virtually all wealthy farmers own life insurance in trusts, say estate tax lawyers who specialize in working with farmers. Id.

169. See Small Business Tax Revision Act of 1958, Pub. L. No. 85-866, $\$ 206,72$ Stat. 1606, 1681 ; see also 104 CoNG. REc. S17087-89 (daily ed. Aug. 12, 1958) (statement of Sen. Kerr summarizing the provisions of the "small-business men's tax-relief bill" [sic]).

170. 104 CoNG. REC. $\$ 17089-90$ (daily ed. Aug. 12, 1958) (statement of Sen. Javits).

171. 104 CoNG. REC. \$2029 (daily ed. Feb. 13, 1958) (statement of Sen. Pastore).

172. Id.

173. S. REP. No. 85-1237, at 12 (1958). The Senate Report hinted, however, that one of the main benefits of the extension of time to pay estate taxes would bepsychological, not practical, as small business owners would eventually have to pay the full estate tax liability ("For those [estates] which did qualify [for the extension] it would prove of great help and would also have a psychological impact on businessmen-giving a benefit which cannot be measured."). Id at 12 . 
As one Senator reasoned, "what is good for small business is good for the country."174

The link between small business health and national prosperity seems to have been asserted as an article of faith, without significant macroeconomic analysis. That a small business might not generate enough income to pay estate taxes was not viewed as proof of its lack of economic vitality, but rather as an indication that it deserved special protection. Large corporate conglomerates were described as an anathema to a system of free enterprise; small businesses were essential to the system's survival. ${ }^{175}$ In their statements, congressional leaders were careful to emphasize that the proposed extension of time to pay estate taxes would not necessarily result in the loss of revenue: "[T]he estate tax provision represents a spread forward of tax payments but does not reduce the amount which will ultimately have to be paid with respect to any specific estate."176 In this way, the extension of time to pay estate taxes was presented as a revenue-neutral change to the law. ${ }^{177}$

When refinements were made to $\S 6166$ 's extension rules in $1976,{ }^{178}$ lawmakers again emphasized the unique nature of closely held businesses. They reiterated the importance of the extension, insofar as a closely held business' loss of one of its main owners might be devastating to a company's cash flow and "it may take several years before the business can regain sufficient financial strength to generate enough cash to pay taxes."179

174. 104 CONG. REC. SI3775 (daily ed. July 15, 1958) (statement of Sen. Sparkman). Senator Sparkman lauded small businesses as "the greatest job makers. They are great consumers. They are great producers." Id.

175. 104 CoNG. REC. S15793 (daily ed. Jan. 28, 1958) (statement of Sen. Javits) ("[A]lthough not removing any Federal estate tax in those cases, it is hoped that by spreading out the period over which the estate tax may be paid it will be possible for the estate tax in most cases to be paid for out of earnings of the business, or at least that it will provide the heirs with the time to obtain funds to pay the Federal estate tax without upsetting the operating of the business. It is believed that this provision is particularly important in preventing corporate mergers and in maintaining the free enterprise system.").

176. Id.

177. Revenue neutrality refers to the concept that " $a$ change or proposed change in the tax system which results in the same amount of revenue. The concept does not include neutrality as to each taxpayer but does imply revenue neutrality as to all taxpayers or the revenue system. A neutral change may result in increased taxes for comporations and high income individuals, but offset by lower taxes on other taxpayers." ROBERT Sellers SMITh, WeST's TAX LAw Dictionary 769 (2004).

178. In enacting changes to $\$ 6166$ in 1976, the Joint Committee on Taxation notes that existing law was "inadequate to deal with the liquidity problems experienced by estates in which a substantial portion of the assets consist of a closely held business or oher illiquid assets. In many cases, the executor was forced to sell a decedent's interest in a farm or other closely held business in order to pay the estate tax." Staff of Joint Comm. ON TaXation, Publ'n No. JCS-33-76, General Explanatron of the TaX REFORM ACT OF 1976, at 546 (1976).

179. Id. 
Congress also believed that the law needed to be more flexible in granting extensions of time to pay taxes where estates were comprised of closely held businesses. ${ }^{180}$ Small business owners were a favored class of taxpayers who were singled out for special treatment.

\section{Family Values: Perspectives on the Family}

The great variety in existing estate tax definitions of the family underscores the importance of the family to the overall system of wealth transfer taxation. Indeed estate taxation arose in response to the desire on the part of wealthy individuals to transfer wealth to their children. ${ }^{181}$ As people accumulated great fortunes that could not be consumed in a single lifetime, the government sought to tax the transfer of wealth from one generation to the next. ${ }^{182}$ In response to early estate tax legislation, taxpayers became creative in minimizing their tax bills, ${ }^{183}$ and the law in turn became more complicated. ${ }^{184}$

Apart from taxpayer creativity, one reason for the complexity of current estate tax rules is the complexity of modern family arrangements themselves. Family households constitute the majority of American households. ${ }^{185}$

180. "[W] here a substantial portion of the estate consists of illiquid assets other than a farm or other closely held business, it has been extremely difficult to obtain an extension on the ground of 'undue hardship' because the Internal Revenue Service generally takes a restrictive approach toward granting such extensions." H.R. REP. No. 94-1380, at 3384-85 (1976). Furthermore, obtaining a bond for estate tax payment requirements had become difficult or expensive for executors. Id. at 3385 ("[M]any executors have found it both difficult and expensive to obtain a bond to satisfy the extended payment requirements. Therefore, many executors refuse to elect the extended payment provisions because they must remain personally liable for tax for the entire length of the extension.").

181. WILLBANKs, supra note 18 , at 5 (noting also that war played a role in the enactment of an estate tax); see generally RandolPH E. PAul, Federal ESTATE and Gift TAXATION (1942); MAX WEST, ThE INHERITANCE TAX (1893).

182. As Professor Willbanks explains, "Inheritance was viewed as a windfall increasing the ability to bear the burden of taxation." WLLBANKS, supra note 18 , at 5 .

183. See, e.g., DAVID ROCKEFEL LER, MEMOIRs 73-75 (2002) (on John D. Rockefeller, Jr.'s creation of significant trusts for his family in 1934).

184. The estate tax was enacted in 1916. See WH, B BANKS, supra note 18, at 5 . The first significant reform of the estate tax occurred with the enactment of the Revenue Act of 1948, Pub. L. No. 80-471, 62 Stat. 110 .

185. U.S. CENSUS BUREAU, HouseHoldS AND FaMILES: 2000, at 2 tbl. 1 (2001), available at http://www,census.gov/prod/2001 pubs/c2kbr01-8.pdf. A family household consists of a "householder," the person in whose name the housing unit is owned, being bought or rented and "one or more people living together, who are related to the householder by birth, marriage or adoption," with or without other people unrelated to the householder. $I d$. at 2 . Families constitute $68.1 \%$ of all households. A slim majority $(51.7 \%)$ of households are comprised of married taxpayers. The rest are female householders with no 
Approximately $60.7 \%$ of all family households include children, ${ }^{186}$ but very few families resemble the traditional model of a working husband and a stayat-home wife. ${ }^{187}$ According to the most recent census data, most women work. ${ }^{188}$ Many children live with one parent or neither parent, although the majority $(68.7 \%)$ of all children live with two parents. ${ }^{189}$ Multigenerational households (e.g., a grandparent, parent and child all living together) are a significant percentage of all households. ${ }^{190}$ Of all persons over the age of fifteen years, a large percentage $(18.5 \%)$ are divorced and remarried, but only $27.1 \%$ have never married. ${ }^{191}$ These statistics point to the great variation in family composition. In light of the many ways in which American families differ from the traditional model, complexity in the estate tax law is perhaps

husband present $(12.2 \%)$, male householders with no wife present $(4.2 \%)$ and two or more unrelated persons living together $(6.1 \%)$. Approximately one-quarter of all households $(25.8 \%)$ consist of single taxpayers living alone. $I d$.

186. U.S. Census Bureau, AMERICA's Familes and Living ARRANGements: 2004, at tbl. F1 (2004), available at http:/www.census.gov/population/www/socdemo/hh-fam/cps2004.html.

187. Donald Hernandez, U.S. Census Buread, We The AMERICAN Children, at 2 fig. 1 (1993), available at http:/www.census.gov/apsd/wepeople/we-10.pdf; see also JASON FiELDS, U.S. CENSUS Bureau, ChILdREN's Living ARRANGEMENTS AND ChiaraCteristics: MARCH 2002, at 9 tbl. 4 (2003), available at http://www.census.gov/prod/2003pubs/p20-547.pdf; ARLENE F. SALUTER \& TERRY A. Lugaila, U.S. Census Bureau, Current population Rerorts, Population Characteristics: MARÍtal Status and Lrving ARRAngements: March 1996, at 4 tbl. D (1998), available at http://www.census.gov/prod/3/98pubs/p20-496.pdf.

188. Renee E. Spraggrns, U.S. Census Bureau, We the People: Women and Men in the UNITED STATES, at 10 fig. 9 (2005), available at http://www,census.gov/prod/2005 pubs/censr-20.pdf. Employment outside the home is somewhat negatively correlated with having children. U.S. CENSUS BUREAU, AMERICA'S FAMILIES AND LIVING ARRANGEMENTS: 2003, at tbl. FG1 (2003), available at http:/www,census.gov/population/www/socdemo/hh-fam/cps2003/tabFGl -all-1.pdf.

189. FIELDs, supra note 187 , at 9 tbl. 4 . As of March, $2002,22.8 \%$ of all children were living with only their mother, $4.6 \%$ were living with only their father, and $4.0 \%$ were living with no parent. Id.

190. For the year 2000 , there were $3,929,122$ multigenerational households, representing $3.7 \%$ of all households. U.S. CENSUS BUREAU, MULTIGENERATIONAL Housemolds for the UNited STATES, STates, AND FOR PUERTO RICO: 2000 (2001), available at http:/www.census.gov/population/www/cen2000/phct1 7.html. Of those multigenerational households, $65.2 \%$ were comprised of a householder with a child and grandchild, $32.8 \%$ were comprised of a householder with parent and child, and $2.0 \%$ were comprised of a householder with parent, child, and grandchild.

Five million eight hundred thousand (3.6\%) of all people aged 30 and over living in households report that they were living with grandchildren under the age of eighteen years. TAVIA SIMMONS \& JANE LAWLER DYE, GRANDPARENTS LIVING WITH GRANDCHILDREN: 2000 (2003), available at http:/www.census.gov/ prod $/ 2003$ pubs $/ \mathrm{c} 2 \mathrm{kbr}-31$.pdf. Just under half $(42 \%)$ reported that they had primary responsibility for their grandchildren. Id.

191. Rose M. KreIder \& Tavia Simmons, Martal Status: 2000 (2003), available at http:/www,census.gov/prod/2003pubs/c2kbr-31.pdf. This report does not include any meaningful information about same-sex couples, as "[i]ndividuals who were living together (unmarried people, people in common-law marriages) reported the marital status which they considered most appropriate." Id. at 1. 
not surprising, given that the estate tax arose in response to family wealth transfers. ${ }^{192}$

Apart from its revenue-generation function, viewed in a larger cultural context of family relationships, the estate tax rules perform two distinct functions: first, they acknowledge the personal and economic interconnectedness of individuals within families, and second, to a certain extent, they take into account diversity in family arrangements. ${ }^{193}$ From the

192. See supra notes 181-84 and accompanying text.

193. The family has been a traditional focus of women's long-standing critiques of law and social policy. See generally Myra Marx Ferree, Beyond Separate Spheres: Feminism \& Family Research, $4 \mathrm{~J}$. MARRIAGE \& FAMLY 866 84 (1990); Marie Withers Osmond \& Banie Thorne, Feminist Theories: The Social Construction of Gender, in SOURCEBook of FAMLY Theories 591 (William Doherty et al. eds., 1993). Nineteenth century activists, for example, advocated for women's right to vote on the ground that laws relating to the family were inadequate to protect women's interests. See, e.g., Declaration of Sentiments, reprinted in IHISTORY OF WOMAN SUFFrA GE 70-71 (Elizabeth Cady Stanton et al, edis., AYER Co., Publishers 1985) (1848-1861) (statement of women's rights activists at Seneca Falls, New York in 1848). Historians typically view the Declaration of Sentiments as the seminal document that commemorates the beginning of the woman suffrage movement. See, e.g., AILEEN KRADrroR, IDEAS OF THE WOMAN SUFFRAGE MOVEMENT 1890-1920, at 1 (1965). On nineteenth centurywomen's voting rights and other activism, see Ariella $\mathrm{R}$. Dubler, In the Shadow of Marriage: Single Women and the Legal Construction of the Family and the State, 112 YALE L.J. 1641 (2003); RevaB. Siegel, She the People: The Nineteenth Amendment, Sex Equality, Federalism and the Family, 115 HARV. L. Rev. 947 (2002). In an address to the state legislature in 1854, Elizabeth Cady Stanton critiqued the laws of marriage and the fanily:

Look at the position of woman as wife. Your laws relating to marriage-founded as they are on the old common law of England, a compound of barbarous usages. [Women] can get no redress for wrongs in her own name in any court of justice. She can neither sue nor be sued . . . L Look at the position of woman as mother. There is no human love so strong and steadfast as that of the mother for her child; yet behold how ruthless are your laws touching this most sacred relation... . The father may apprentice his child, bind him out to a trade, without the mother's consent--yea, in direct opposition to her most earnest entreaties, prayers and tears.

ELZABETH CADY STANTON, ADDRESS TO THE LEgISLATURE OF THE STATE OF NEW YoRK, reprinted in I HistoRY OF WOMAN SUFFRAGE, supra, at 595-605. To Stanton, the law rendered women invisible and powerles, depriving them of legal personhood and the ability to cane for their children.

Most formal obstacles to women's legal equality were removed in the century following Stanton's famous statement. See, e.g., Reed v. Reed, 404 U.S. 71 (1971) (statute invalid where male is preferred as administrator of an intestate estate); Frontiero v. Richardson, 411 U.S, 677 (1973) (female military personnel cannot be required to prove dependency of spouse in order to obtain certain benefits, where male personnel are not required to do so). Feminist activists and scholars nevertheless have continued to examine the family as one source of ongoing inequality between men and women. See, e.g., Herma Hill Kay, Equality and Difference: The Case of Pregnancy, 1 BERKELEY WOMEN's L.J. 1 (1985); Dorothy Roberts, Spiritual and Menial Housework, 9 YALE J.L. \& FEMINISM 51 (1997); Katharine Silbaugh, Turning Labor into Love: Housework and the Law, 91 Nw.U.L. REv. I (1996); Jana B. Singer, Alimony and Efficiency: The Gendered Costs and Benefits of the Economic Justification for Alimony, 82, GEo. L.J. 2423 (1994). Sociologist Jessie Bernard famously described that "there are two marriages in every marital union-his and hers-and that his is better than hers." Maxine Baca Zinn, Feminism and Family Studies for a New Century, 571 ANNALS 42, 46 (2000) (describing Jessie Bernard's classic text, THE FUTURE OF MARRIAGE 
perspective of certain family law scholarship and gender theory, however, the estate tax rules are flawed in theoretical and practical terms because they fail to recognize the full diversity of American households and they valorize market labor. This Part borrows the lens of gender theory to explore how the current tax rules embrace progressive constructions of the family, but do not go far enough in recognizing the complexity of human household relationships.

\section{A. Tax Rules and Interconnectedness}

Typically women's interests have been said to center on "caretaking and relationships, particularly with dependents." 194 Recognition of the multiplicity of human connectedness reinforces values and knowledge that some scholars suggest are unique to women: an understanding that no person is ever wholly independent from others. ${ }^{195}$ To the extent they are concerned especially with the identities (and business activities) of a particular transferor, transferee and his or her respective family members, ${ }^{196}$ the estate tax rules of $\S \S 2036,2032 \mathrm{~A}$ and 6166 are consistent with a jurisprudence of connectedness. That jurisprudence would suggest that no person is a classically individual rational actor, and every transfer must be viewed in its larger human context. ${ }^{197}$

(1972)). Law professor Martha Fineman has extended and deepened that critique, exploring the extent to which the canetaking work of families is performed largely by women, even though they may be engaged in work outside the home as well. Martha Albertson Fineman, Cracking the Foundational Myths: Independence, Autonomy, and Self Sufficiency, 8 AM. U. J. GENDER SOC. POL'Y \& L. 19-20 (2000); see also Ann Shalleck, Foundational Myths and the Reality of Dependency: The Role of Marriage, 8 AM. U. J.GENDER SOC. POL'Y \&L. 197, 199-201 (2000). Professor Fineman argues that by “privatizing" women's caretaking activities in families, the state has been able to avoid engaging in that activity itself. Martha Albertson Fineman, Masking Dependency: The Political Role of Family Rhetoric, 11 VA. L. REv. 2181, 2187 (1995).

194. Mary Becker, Patriarchy and Inequality: Towards a Substantive Feminism, 1999 U. CHI. LEGAL F. $21,49$.

195. See Robin West, Jurisprudence and Gender, 55 U. Crul. L. REv. 1 (1988). Professor West explains that

[w] recurrent and critical material experiences: the experience of pregnancy itself; the invasive and "connecting" experience of heterosexual penetration, which may lead to pregnancy; the monthly experience of menstruation, which represents the potential for pregnancy; and the post-pregnancy experience of breast-feeding.

Id. at $2-3$.

196. See supra notes 4, 97-101 and accompanying text; see also infra Part 1.B.3 (for purposes of $\S 2032 \mathrm{~A}$, "qualified use" of property may be by decedent or certain members of decedent's family).

197. On the role of the rational actor in Law and Economics scholarship, see generally STEVEN SHAVELL, ECONOMIC ANALYSIS OF LAW 1 (2004) ("Given the characterization of individuals' behavior as 
That women in particular value human connectedness is suggested by the work of psychologist Carol Gilligan. ${ }^{98}$ In her famous study of gender roles, Gilligan details the distinct responses of a boy and a girl to the same hypothetical involving a drug that a protagonist needs but cannot afford for his dying wife. ${ }^{199}$ The boy tells his interviewer that to "solve" the dilemma, the hypothetical protagonist should steal the drug. ${ }^{200}$ The girl tells her interviewer that the hypothetical protagonist should reason with the pharmacist and explain that he needs the medicine for his sick wife. ${ }^{201}$ Gilligan characterizes the boy's response as exhibiting a "logic of justice," whereas the girl's response demonstrates an "ethic of care." If the logic of justice centers on a single decision-maker's determination of values, then the ethic of care appeals to human sympathies and connections in search of an equitable solution. ${ }^{203}$ Gilligan's work illustrates just one of many possible ways in

rational, the influences of legal tules on behavior can be ascertained. This can be done with definitude in 'the world of the models, because all relevant factors about individuals' desires, knowledge, and the environment will have been made explicit.").

198. See Carol Gllligan, in a Different Voice: Psychological Theory and Women's Development (1982) [hereinafter IN A Different Volce]; Mapping the Moral Domain: A CONTRIBUTION OF WOMEN'S THINKING TO PSYCHOLOGICAL THEORY AND EDUCATYON (Carol Gilligan et al. eds., 1988); see also MARY FIELO BELENKY ET AL., WOMEN's WAYS OF KNOWING (1986). Gilligan's work has been criticized as difficult to test empirically, See, e.g., Lawrence J. Walker, Sexism in Kohlberg's Moral Psychology?, in MORAL DEVELopment: AN INTRODUction 83-107 (William M. Kurtines \& Jacob L. Gewirtz eds., 1995). For an overview of critical responses to Gilligan's work, see Sara Jaffee \& Janet Shibley Hyde, Gender Differences in Moral Orientation: A Meta-Analysis, 126 PSYCrol. BuLt. 703 (2000); Maureen Rose Ford \& Caroi Rotter Lowery, Gender Differences in Moral Reasoning: A Comparison of the Use of Justice and Care Orientations, $50 \mathrm{~J}$. PERSONALITY \& SOC. PSYCHOL. 777 (1986).

199. In A DIFFERENT VoICE, supra note 198, at 25-29.

200. Id. at 26 .

201. Id. at 27-28.

202. Id. at 29-30. The "ethic of care" has been critiqued as reinforcing traditional gender stereotypes.

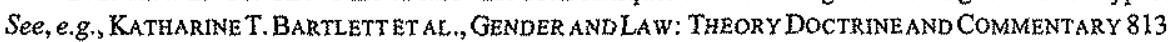
(3d ed. 2002). Law professor Kathryn Abrams has suggested that women's assumption of nurturing roles is a response 'to exployers' failure to accommodate workers who are also parents, or spouses' failure to share the domestic tasks that fall disproportionately to mothers who continue to work." Kathryn Abrams, Social Construction, Roving Biologism, and Reasonable Women, 41 DEPAUL, L. REV. 1021, 1026(1992). In contrast, law professor Richard Epstein suggests purely biological bases for women's behavior:

The nurturing instincts usuallyattributable to women are a set of attitudinal adaptations that reduce the cost of doing activities that help promote the survival of both her and her offspring. Although modern women operate in settings far different from those of their ancient mother, the initial tendency still remains: If nurturing brings greater pleasure or requires lower costs for women than for men, then we should expect to see women devote a greater percentage of their resources to it than men.

Richard A. Epstein, Gender Is for Nouns, 41 DEPAut L. REV, 981, 990 (1992).

203. For a general discussion of the impact of Gilligan's work on legal reasoning, see Carrie Menkel- 
which men and women may be different, but suggests that women place a particular premium on human relationships. ${ }^{204}$ This provides a context for evaluating the estate tax's emphasis on family relationships and suggests the way that the estate tax embraces the jurisprudence of connectedness.

The estate tax law's preferences (and penalties) for families acknowledge the human dimension of wealth transfers, particularly that the economic realities of any one transfer may depend on the identity of either the donee of an inter vivos gift or the legatee of a death-time transfer. ${ }^{205}$ Transfers to family members are treated in some instances more favorably than transfers to strangers, ${ }^{206}$ but replacement of a removed trustee is fraught, with greater potential estate tax penalties when the replacement is a family member instead of a stranger. ${ }^{207}$ The estate tax rules' embrace of a jurisprudence of connectedness is not complete, however. The rules do not fully account for the multi-dimensional aspects of human relations. The existence of family hostility, for example, is irrelevant to the determination of whether a corporation is "controlled" for purposes of $\S 2036$ (a)(1)'s estate tax inclusion rule. ${ }^{208}$ The definition in $\S 2036(\mathrm{~b})(2)$ focuses on the holdings of the taxpayer and family members without regard to the qualitative nature of the interpersonal relationships (i.e., whether a person is in fact "controlled" by another). Similarly whether a particular family member-trustee is in fact "subordinate" with respect to the taxpayer-transferor is irrelevant for purposes of $\S 2036(\mathrm{a})(2)$ 's inclusion rule. ${ }^{209}$ The only relevant criterion is whether the trustee is a member of the prohibited class. So the tax laws recognize interconnectedness to a certain extent, but efficient application of the tax rules requires the overlay of bright line rules that may or may not reflect the realities of particular family relationships. The estate tax rules recognize some, but not all, connectedness between individuals.

Meadow, Portia in a Different Voice, I BerkeLey WoMen's L.J. 39, 43-49 (1985).

204. Although a thorough discussion of the nature of gender differences is beyond the scope of this article, for an overview of the ways that gender theories are applied to jurisprudence, see MARTHA Chamallas, introduction to Feminist Legal. Theory 15-22 (2d ed. 2003).

205. See discussion supra Parts I.A-C.

206. E.g., 1.R.C. $\$ 2032 \mathrm{~A}$ (b) (qualified real property must have been used for a qualifying use by a member of a decedent's familiy).

207. E.g., id. $\$ 2036(a)(2)$.

208. See id. $\$ 2036($ a)(1); see also Lawrence Stern, Attribution Rules' Effect on Stock Redemptions when Family Hostility Exists, 38 Sw. L.J. 887 (1984).

209. E.g., L.R.C. $\S 2036(a)(2)$. 


\section{B. Tax Rules and Diversity in Families}

\section{How the Definitions Succeed}

Family law scholarship draws attention to the diversity in American families. That diversity requires the estate tax definitions of "family" or "related" persons to embrace modern family configurations to some extent. For example, perhaps in a nod to the prevalence of divorce, $\S 2036(\mathrm{~b})(2)$, which is applicable to $\S 2036$ (a)(1), provides that the holdings of a taxpayertransferor's spouse will not be aggregated with the taxpayer's if the spouses are separated under a decree of divorce or separate maintenance. ${ }^{210}$ In possible acknowledgment of multigenerational families (and the likelihood that an adult may be taking care of elderly parents as well as minor children), a parent is a "related or subordinate" party for purposes of $\$ 2036(a)(2)$, and therefore cannot be removed or replaced as a trustee of a trust created by the taxpayer. ${ }^{211}$ Similarly, siblings are defined as members of the "family" for purposes of $\S \S 2032 \mathrm{~A}$ and $6166,{ }^{212}$ recognizing the role of extended family in closely held or family-owned businesses. Given the irregular nature of the American family, these expansive definitions of families are appropriate.

\section{How the Definitions Fail}

At least in the popular imagination, the term "family" calls up an image of a grouping of persons related by blood or marriage. The stereotypical family is organized around a heterosexual married couple and their descendants. ${ }^{213}$ The estate tax rules are oriented toward this vision of the nuclear family, allowing for some variations within a traditional bandwidth. Yet the multiple estate tax definitions of family do not recognize the same variations on the traditional structure. For example, $\$ 2032 \mathrm{~A}$ is the only one of the four provisions to include within the definition of "family" stepchildren and spouses of lineal descendants of the transferor or the transferor's spouse. ${ }^{214}$ Likewise, $\$ 2036(\mathrm{~b})(2)$ 's definition of a controlled corporation is

210. $l d . \S \S 2036(\mathrm{a})(1),(\mathrm{b})(2), 318(\mathrm{a})(\mathrm{l})$.

211. Rev. Rul. 95-58, 1995-2 C.B. 1; see I.R.C. $\$$ 2036(a)(2),672(c). This example assumes that the parent is not a nonadverse party with respect to the taxpayer-transferor. I.R.C. $\$ 2036(\mathrm{a})(2)$.

212. I.R.C. $\$ \$ 2032 \mathrm{~A}$ (e)(2)(D), 6166(b)(2)(D), 267(c)(4).

213. Consider, for example, that all persons shown in Figure A likely would be considered members of Dora Ewing's extended "family" as the term is used popularly.

214. I.R.C. $\$ 2032 \mathrm{~A}(\mathrm{e})(2)(\mathrm{D}) ;$ cf. id. $\$ \$ 2036(\mathrm{a})(1),(\mathrm{b})(2), 318(\mathrm{a})(\mathrm{l})(\mathrm{A}), 2036(\mathrm{a})(2), 672(\mathrm{c})$, $6166(\mathrm{~b})(2)(\mathrm{D})$. For purposes of $\S 2036(\mathrm{a})$, the failure to include stepchildren, as an example, within the 
the only one of the four subject Code sections not to include siblings. ${ }^{215}$ In the case of $\$ 2036$, this seems to be an explicit policy choice in light of the section's concern with control. ${ }^{216}$ Whatever the reasons, though, the definitions are inconsistent in their recognition of the diversity of families.

The inconsistency of the estate tax's definitions of family is matched by their underinclusivity. Existing estate tax definitions recognize traditional families, stepfamilies and extended families, but they do not recognize nonmarital associational relationships that some people consider to be "family." The estate tax maintains this approach even in the face of state laws that grant some of those "families" limited legal recognition. For example, under New Jersey's Domestic Partnership Act, ${ }^{217}$ opposite sex partners who are both sixty-two years of age or older and same sex partners (who are not permitted to marry under New Jersey law) may register as domestic partners. ${ }^{218}$ Registration of the domestic partnership is meant to afford

definition of family can be read as a pro-taxpayer rule. For example, a stepchild's holdings will not be aggregated with the taxpayer-transferor's for purposes of the definition of a controlled corporation under $\$ 2036$ (a)(1). See supra notes 21-25 and accompanying text. Likewise, to the extent that the descendants of a taxpayer's spouse are not "related" to the taxpayer, the taxpayer presumably could remove and replace a stepchild-trustee without negative tax consequences. See supro notes 36-43 and accompanying text. Consider, however, that for purposes of $\$ 6166$, the failure to include stepchildren within the definition of "family" acts to the detriment of the taxpayer. A stepchild's holdings will not be aggregated with the decedent's for purposes of the 45-person ownership cap. See I.R.C. $\S 6166(\mathrm{~b})(1)(B)(i i)$.

215. See 1.R.C. $\$ 2036($ b) $(2)$. As with stepchildren, the failure to include siblings within the definition of family can be read as a pro-taxpayer rule. See supra notes $21-25,214$ and accompanying text.

216. The section perhaps reflects the belief that in the context of a family business, siblings, by virtue of natural rivalry or divergent financial needs, are not likely to control one another. I am grateful to Professor Ronald $\mathrm{H}$. Jensen for this insight.

217. N.J. STAT. ANN. \$26:8A-1 (West 2005).

218. A domestic partner is defined as "a person who is in a relationship that satisfies the definition of a domestic partnership," where domestic partnership is defined as a "familial relationship" in which individuals "choose[] to live together in important personal, emotional and economic committed relationships with another individual." Id. $\$ 26: 8 \mathrm{~A}-3$. The requirements of a domestic partnership are:

(1) Both persons have a common residence and are otherwise jointly responsible for each other's common welfare as evidenced by joint financial arrangements or joint ownership of real or personal property, which shall be demonstrated by at least one of the following:

(a) a joint deed, mortgage agreement or lease;

(b) a joint bank account;

(c) designation of one of the persons as a primary beneficiary in the other person's will;

(d) designation of one of the persons as a primary beneficiary in the other person's life

insurance policy or retirement plan; or

(e) joint ownership of a motor vehicle;

(2) Both persons agree to be jointly responsible for each other's basic living expenses during the domestic partnership;

(3) Neither person is in a marriage recognized by New Jersey law or a member of another domestic partnership; 
domestic partners certain legal benefits under state law. ${ }^{219}$ Yet for federal estate tax purposes, these persons are not considered members of the same "family"220 in the several ways that the statutes define that term. Consider, for example, a variation on Hypothetical $2 .{ }^{221}$

(4) Neither person is related to the other by blood or affinity up to and including the fourth degree of consanguinity;

(5) Both persons are of the same sex and therefore unable to enter into a marriage with each other that is recognized by New Jersey law, except that two persons who are each 62 years of age or older and not of the same sex may establish a domestic partnership if they meet the requirements set forth in this section;

(6) Both persons have chosen to share each other's lives in a committed relationship of mutual caring;

(7) Both persons are at least 18 years of age;

(8) Both persons file jointly an Affidavit of Domestic Partnership; and

(9) Neither person has been a partner in a domestic partnership that was terminated less than 180 days prior to the filing of the current Affidavit of Domestic Partnership, except that this prohibition shall not apply if one of the partners died; and, in all cases in which a person registered a prior domestic partnership, the domestic partnership shall have been terminated in accordance with the provisions of section 10 of P.L. 2003 , c. 246 (C.26:8A-10).

Id. $\$ 26: 8 \mathrm{~A}-4$.

219. The law is meant to provide, among other things, for protection against discrimination in housing, eligibility for coverage of state employees' domestic partners under certain state-administered benefit programs, hospital visitation rights, and other health benefits to those who register as domestic partners. Id. § 26:8A-2. For an overview New Jersey's Domestic Partnership Act, see Thomas Prol \& Daniel Weiss, Lifting a Lamp: Will New Jersey Create a Safe Harbor for Gay and Lesbian Immigration Rights?, 227 N.J.LAw. 22 (2004); Felice T. Londa, The Pendulum of Same-Sex Marriage Rights, 13 N.J. LAW. WKLY, NEWSPAPER 1759 (2004).

220. Because DOMA provides that for federal purposes, marriage is defined as a legal union between a man and a woman, 1 U.S.C. $\$ 7$ (2006), a New Jersey domestic partnership likely would not be recognized for federal estate tax purposes. See also CAL. FAM. CODE $\S \S 297-299.6$ (West 2005) (California's domestic partnership law).

221. For consistency in illustration, Hypothetical 8 envisions Dora Ewing's acquiring an unmarried opposite-sex partner. The same results would obtain with a same-sex partner, regardless of whether Dora Ewing and the partner were married, parties to a civil union or registered domestic partners. See supra note 16.

If same-sex marriage were to be recognized for federal tax purposes, the provisions of $\$ \S 2036(\mathrm{a})(1)$, $2036(\mathrm{a})(2), 2032 \mathrm{~A}$ and 6166 , among others, probably would not need to be revised significantly in order to accommodate this new type of family artangement. See supra note 16. This assumes that a taxpayer's same-sex partner would be defined for federal tax purposes as his or her "spouse." If this were not the case, the statutes would need to be revised so that the same-sex partner is brought within the definition of family member. If same-sex marriage remains unrecognized for federal tax purposes, though, study of the conflicting meanings of family in the estate tax law at least invites reconsideration of the issue. In claiming the right to marry, same-sex couples knowingly invoke all of those benefits and burdens of the tax system. See supra note 16. Same-sex marriage activists evidence awareness of the dual beneficialmburdensome nature of the estate tax systern in advising taxpayers against selective self-application of the tax rules. See Gay and Lesbian Advocates and Defenders, Navigating Income Taxes for Married Same-Sex Couples, www.glad.org/rights/taxes_for_married_couples.html (same-sex married couples should be consistent in their approach to tax rules "to prevent others from using the designation 'single' to argue or prove that a 
Hypothetical 8. Assume that Dora Ewing survives her husband, Roland Lucas, and later enters into a long-term committed relationship with Mr. Z (not shown in Figure A). Dora Ewing and Mr. $Z$ live together in a marital-like relationship, but they are not married. When they are both residents of the State of New Jersey and over the age of sixty-two years, they register their domestic partnership with the applicable state authorities. Further assume that Dora Ewing owns 5\% of Company Y's total outstanding stock. Company $\mathrm{Y}$ has only one class of stock, and all shares have the same voting rights. Pursuant to Company Y's by-laws and the applicable shareholder agreement, any shareholder may transfer an underlying equity interest in any stock without also transferring the voting rights associated with the stock. One year before her death, Dora Ewing transfers to Friend Frank, an unrelated third party (not shown in Figure A), the underlying equity interest in all of her Company $Y$ stock. At the time of Dora Ewing's death, Dora Ewing retained her voting rights and $\mathrm{Mr}$. $Z$ owns $95 \%$ of the Company $Y$ stock. At the time of her death, Dora Ewing and Mr. $Z$ had lived together for over 25 years.

In this case, Dora Ewing's estate can avoid entirely the application of $\S 2036(\mathrm{~b})(2)$ because she personally has the right to vote only five percent of Company Y stock. ${ }^{222}$ Mr. Z's $95 \%$ ownership is not attributed to her under $\S 318$ and $\$ 2036(\mathrm{~b})(2)$, even though Dora Ewing and Mr. Z lived together in a domestic partnership recognized by state law, and the fact that his ownership would be attributed to her if they had been married. ${ }^{223}$ Unlike in Hypothetical 1 and Hypothetical 2, the full value of the stock transferred to Friend Frank therefore escapes inclusion in Dora Ewing's gross estate under $\S 2036(\mathrm{~b})(1),{ }^{224}$ notwithstanding her long-term, family-like relationship with Mr. Z, the Company's majority owner. To facilitate application of the law, the Code employs a bright line test for determining who is a member of the family. ${ }^{225}$ The Code does not look on a case-by-case basis at each taxpayer's transfer.

person is not really married when that issue arises in other legal contexts."); see also Dorn, supra note 16, at 23 (suggesting that married same-sex couples should "act as though they were bound by Code provisions limiting intrafamily wealth transfers. Opting into such requirements would also avoid the need for 'emergency planning' if DOMA were to be overturned or repealed and same-sex marriages were to become recognized for Federal tax purposes.").

222. See supra note 221 .

223. See supra note 221. Contrast this with the result in Hypothetical 2 where Dora Ewing's ownership was aggregated with her father's.

224. I.R.C. $\$ 2036($ b) $(1),(2)$.

225. The bright-line test in some sense may be a function of evidentiary concerns. That is, to avoid undertaking a case-by-case analysis of all of a decedent's transfers, the law establishes a rule for who is a member of the decedent's "family." Who is "family" is determined by legal relationships that can be determined with certainty, as birth, death and marriage records are for the most part documented by the state, making it easy to prove these relationships. 
In Hypothetical 8, the federal estate tax law's failure to recognize the state domestic partnership enables a taxpayer to escape taxation on a transaction that substantively resembles one that is taxed under current law..$^{226}$ But there are situations in which the law's failure to recognize nonmarital families will render the taxpayer ineligible for certain tax benefits. Consider, for example, this variation on Hypothetical 7.

Hypothetical 9. Assume as in Hypothetical 7 that Dora Ewing survives her husband, Roland Lucas, and later enters into a long-term committed relationship with Mr. Z (not shown in Figure A). Dora Ewing and Mr. $Z$ live together in a marital-like relationship, but they are not married. When they are both residents of the State of New Jersey and over the age of 62, they register their domestic partnership with the applicable state authorities. Further assume that four years before her death, Dora Ewing inherits Greenacre from her father, William Ewing. Greenacre is real property located in the United States that is used in a family-owned business operated by Dora Ewing. At her death, Dora Ewing bequeaths Greenacre to her long-time companion, Mr. Z. Assume that Dora Ewing's executor elects to have \$ 2032A apply to the estate and files the necessary recapture agreement.

In Hypothetical 9, Dora Ewing's estate will not be eligible for the application of the special valuation rules of $\S 2032 \mathrm{~A}$ because it does not meet the threshold requirements, ${ }^{227}$ even though her executor elects to have $\S 2032 \mathrm{~A}$ apply to the estate and files the necessary recapture agreement. ${ }^{228}$ Although Dora Ewing is a citizen and resident of the United States, ${ }^{229}$ and Greenacre is located in the United States, Mr. $\mathrm{Z}$ is not a "qualified heir" of Dora Ewing because he is not her husband. ${ }^{230}$ Greenacre thus is not "qualified real property" and the special valuation rules will not apply. ${ }^{231}$

Just as Dora Ewing's nonmarital relationship means that favorable estate tax valuation rules were unavailable under $\S 2032 \mathrm{~A}$, a similar unavailability of tax benefits occurs under $\S 6166$.

Hypothetical 10. Assume that Dora Ewing dies with a gross estate valued for estate tax purposes at $\$ 10,000,000$. Further assume that the only assets of the estate are $\$ 6,000,000$ in cash and $\$ 4,000,000$ of stock of Company $Y$. Assume that Dora Ewing is one of 50 shareholders of Company Y. Each shareholder, including Dora Ewing, owns 1,000 shares valued at $\$ 4,000$ per share $\left(\$ 4,000,000\right.$ in aggregate) ${ }^{232}$ The corporation has no

226. See supra Hypothetical 2.

227. See supra notes 63-67 and accompanying text.

228. See I.R.C. \$2032A(a)(1)(A).

229. Id. $\S 2032 \mathrm{~A}(\mathrm{a})(1)(\mathrm{A})$; see supra note 64 and accompanying text.

230. I.R.C. $\$ 2032 A(\mathrm{e})(2)(C)$ (lineal descendants are "members of the family").

231. Id. $\$ 2032 \mathrm{~A}(\mathrm{a})(1)(\mathrm{A})$. A similar preclusion from benefits would occur under $\$ 6166$.

232. As in Hypothetical 7, assume that no valuation discounts are applicable. 
other voting stock and all stock has the same voting rights. Of the 49 shareholders other than Dora Ewing, one is her father, William Ewing; one is her brother, James Ewing; one is her son, William Lucas; one is her daughter, Nell Lucas; and the other is Mr. Z, Dora Ewing's long-term companion. The other 44 shareholders are not related to Dora Ewing in any way.

As in Hypothetical 7 above, Company $Y$ is not a closely held corporation with respect to Dora Ewing based solely on her individual holdings; she personally owns only two percent (or 1,000 out of 50,000) of the corporation's voting shares. Furthermore, Dora Ewing's interest in Company Y does not qualify as an "interest in a closely held business" because Company $Y$ does not have fewer than 45 shareholders. ${ }^{233}$ It is true that under $\S 6166(\mathrm{~b})(2)(\mathrm{D})$, Dora Ewing's stock ownership is aggregated with that of her brother, James Ewing; her father, William Ewing, her son, William Lucas; and her daughter, Nell Lucas. ${ }^{234}$ Her ownership is not aggregated with Mr. Z's, though, because he is not a "member" of her "family" under $\S 6166$ (regardless of whether the couple entered into and registered their domestic partnership under New Jersey law, for example). ${ }^{235}$ Company $Y$ therefore is deemed to have 46 total shareholders (i.e., Dora Ewing, Mr. Z and the other 44 individuals who are not related to her in any way) and her estate will be ineligible for the deferred payment provisions of $\S 6166 .{ }^{236}$ This is true even though Dora Ewing and Mr. $Z$ are in a long-term committed relationship with characteristics similar to marriage. Had they been married, their ownership would have been aggregated and Dora Ewing's estate would have qualified for the extension under $\S 6166 .{ }^{237}$ The estate tax law fails to incorporate the attention of family law and gender scholarship to the associational relationships that some people call "families."

\section{Tax Rules and Market Participation}

An additional insight of recent family law scholarship is the way in which women's caretaking activities frequently lead women themselves to become dependent. ${ }^{238}$ According to this theory of "derivative dependency, ${ }^{, 239}$ because

233. I.R.C. $\$ 6166(\mathrm{~b})(1)(\mathrm{C})(\mathrm{ii})$.

234. Id. $\S 6166(\mathrm{~b})(2)(\mathrm{D})$.

235. $l d$.

236. Id. $\$ 6166$ (a).

237. Id. $\S 6166(\mathrm{~b})(2)(\mathrm{D})$.

238. Fineman, Cracking the Foundational Myths, supra note 193, at 21; see also Suzanna Danuta Watters, Breaking Up Is Hard To Do: Comments on Martha Fineman's Foundational Myths, 8 AM. U. J. GENDER SOC. POL'Y \& L. 205, 214 (2000) (criticizing Fineman's work as falling "far short of the kind 
women have primary responsibility for the care of small children and the elderly, they are unable to participate to the same extent as men in wageearning activities and thus become "dependent on the resources necessary for that care. $" 240$

Insofar as the estate tax laws reward market-based activities, such as participation in a family business, ${ }^{241}$ they accord certain benefits to wageearning behavior that are not bestowed on caretaking activities. Yet if the estate tax laws reward market behavior, that is also because the fruits of market labor (i.e., "qualified real property"242 or a closely held business interest ${ }^{243}$ ) are subject to estate taxation. ${ }^{244}$ Caretaking activities, in contrast, do not produce any assets that will be subject to estate taxation, ${ }^{245}$ and the estate tax's failure to provide any benefit for them does not disadvantage the caretaker. The caretaker-taxpayer is in no worse a position than one who engages in qualifying market activities. ${ }^{246}$

\section{Family Unity: Proposals to Resolve the Estate TaX's CONFLiCTING Definitions of FAMILY}

Given the complex and incomplete estate tax definitions of family, it is worthwhile to consider the possibility of reform. This Part IV evaluates five possible approaches to the problem of the conflicting meanings of family in estate tax law. First, this Part considers the adoption of a uniform definition

of radical restructuring that needs to take place.").

239. Fineman, Cracking the Foundational Myths, supra note 193, at 20.

240. $T d$.

241. See I.R.C. $\$ \$ 2032 \mathrm{~A}$ (b)(2) (qualified use is "use as a farm for farming purposes" or "use in a trade or business other than the trade or business of farming"); $6166(\mathrm{~b})(1)(\mathrm{A})$-(C) (only partnership interest or stock in a corporation is counted in determination of estate's eligibility for extension of time to pay estate taxes).

242. See id. \$2032A(a)(1), (b)(1).

- 243. See id. $\$ 6166(\mathrm{a})$, (b)(1).

244. Cf. id. $\S \S 2001$ (estate tax imposed on the taxable estate of every decedent who is a citizen or resident of the United States), 2051 (taxable state means gross estate minus certain deductions), 2031 (the value of the gross estate includes the value at the time of the decedent's death of all property, real or personal, tangible or intangible, wherever situated). Section 2053 permits deductions for expenses, indebtedness and taxes. Section 2054 permits a deduction for losses. Section 2055 provides for deductions for charitable bequests, legacies, devises or transfers. Section 2056 (a) provides for a marital deduction for "the value of any interest in property which passes or has passed from the decedent to his or her surviving spouse, but only to the extent such interest is included in determining the value of the gross estate."

245. Id. $\S \S 2051,2031$.

246. See supra notes 242-43. For an interesting discussion of the role of law in women's social and political advancement, see Darren Rosenblum, Parity/Disparity: The Political Representation of Gender on the Tightrope of Liberal Constitutional Traditions, 39 DAVtS L. REv. 1119 (2006). 
of family for estate tax purposes. Second, this Part contemplates the complete elimination of estate tax rules that penalize taxpayers or award preferences to them based on family relationships. Third, this Part evaluates the desirability of eliminating only the family-based preference rules. Fourth, this Part explores increasing the estate tax exemption in order to reduce the number of taxpayers who must navigate the complex definitions of family. Fifth, this Part suggests revising the language used in the statutes in order to achieve integrity in their interpretation and application.

\section{A. Adopt a Uniform Definition of Family}

Minimizing complexity in the tax law by adopting a uniform definition has a recent precedent. In 2004, the 108th Congress enacted a uniform definition of "child" for certain income tax purposes. ${ }^{247}$ A similar uniform approach to defining "family" in estate tax law would have at least the perception of simplicity. A seemingly unlimited number of uniform definitions could be offered, but this subpart considers the results under two alternate scenarios: (1) the adoption of a "narrow" definition of "related" persons modeled on the definition made applicable to $\S 2036(\mathrm{a})(1)$ by $\S 2036\left(\right.$ b)(2) (i.e., a taxpayer's spouse, children, grandchildrenand parents); ${ }^{248}$ and (2) the adoption of a "broad" definition of family modeled on the definition contained in $\S 2032 \mathrm{~A}$ (i.e., a taxpayer's ancestors, spouse, any lineal descendant of the taxpayer, a lineal descendant of the taxpayer's spouse, any descendant of the taxpayer's parents and the spouse of any lineal descendant of the taxpayer, the taxpayer's spouse or any descendant of the taxpayer's parents). ${ }^{249}$ This subpart evaluates the advantages and disadvantages of each proposal.

247. Working Families Tax Relief Act of 2004, Pub. L. No. 108-311, § 201, 118 Stat. $1166,1169$. The uniform definition of child applies for puxposes of $\$ 2$ (b) (definition of head of household), $\$ 21$ (credit for expenses for dependent care), $\$ 24$ (child tax credit), $\$ 32$ (earned income credit) and $\$ 151$ (exemption for dependents). To qualify as a "child" under the uniform definition, the child must satisfy three requirements: "(1) [r] ]esidency (the child has the same principal place of abode as the taxpayer for more than half the tax year). (2) Relationship (the child is the taxpayer's son, daughter, step-child, brother, sister, step-sibling, or a descendant of any such individual). (3) Age (generally, the child must be under age 19, or 24 if a full-time student)." Congress Enacts the Working Families Tax Relief Act of 2004, 101 J. TAX'N 195 (2004); see also Stephen Winn, Longing for Simplicity: Loopholes Complicate the Work of the Average Toxpayer, KANSAS CITY STAR, Mar. 23, 2005, at B7; Jill Hammon, Tax Planning Never Ends for Professionals, INDLANAPolss STAR, Mar. 14, 2005, at C01; Mike Freeman, New Laws Could Lower Your Tax Bill, SAN DizGO Union-TRib., Feb. 6, 2005, at $\mathrm{H}-2$.

248. See supra note 27 and accompanying text.

249. See supra notes 73-77 and accompanying text. 


\section{Adopt I.R.C. $\$ 2036(b)(2)$ 's Narrow Definition}

Consider the consequences of an across-the-board adoption of the narrow definition of "related" persons made applicable to $\S 2036(\mathrm{a})(1)$ by $\S 2036$ (b)(2). Such a restrictive approach to family is not exclusively progovernment or pro-taxpayer and might result in the under-taxation of some transactions and over-taxation of others, using congressional intent and existing levels of taxation as a referent.

\section{a. Impact on Estate Tax Inclusion}

In the case of the estate tax inclusion rule of $\S 2036(\mathrm{a})(2)$, if the universe of potentially "related and subordinate" persons were limited to a taxpayer's spouse, children, grandchildren and parents, ${ }^{250}$ it would become too easy for the taxpayer to retain control over transferred property but still escape taxation. In particular, a taxpayer could create a trust and retain an unlimited power to remove and replace the trustee with a new trustee from a class that includes the taxpayer's sibling. ${ }^{251}$ Because a sibling would not be a member of the "family" under a narrow definition, ${ }^{252}$ he or she would be treated as a stranger (in a tax sense) to the taxpayer, and there would be no adverse consequences to the taxpayer's retained right to remove and replace. The taxpayer thus could retain effective control over the transferred property, even though this control is precisely the type that Congress believed should trigger inclusion under $\S 2036(\mathrm{a})(2)$. ${ }^{253}$ Too many transfers would escape taxation, and so a narrow uniform definition of family would result in the systematic under-taxation of transactions under $\S 2036(a)(2)$.

\section{b. Impact on Estate Tax Valuation and Payment}

A narrow definition not only would cause under-taxation under $\S 2036(\mathrm{a})(2)$, but also would cause over-taxation under $\S \S 2032 \mathrm{~A}$ and 6166 . For these latter two sections, a narrow definition of family would mean a smaller group of persons whose ownership and business activities could inure

250. I.R.C. $\$ 318(a)$ (1)(A) (incorporated by reference into $\$ 2036(\mathrm{~b})(2)$ 's definition of controlled comporation).

251. See supra note 36 .

252. See supra note 27 and accompanying text.

253. See supra Part II.A. 
to the benefit of the taxpayer. For example, consider again Hypothetical 5 . In that case, Dora Ewing's failure to participate personally in the business is no obstacle to the application of $\S 2032 \mathrm{~A}$ to her estate because the participation of her brother, James Ewing, redounds to Dora Ewing's benefit. ${ }^{254}$ Contrast the results under a narrow definition of family. Under a narrow definition, James Ewing would not be a "member" of Dora Ewing's "family,",25s and so Greenacre would fail the test for "qualified real property." ${ }^{256}$ It then would be ineligible for the special valuation rule under $\S 2032 \mathrm{~A} .{ }^{257}$ By narrowly defining the "family" as a taxpayer's spouse, children, grandchildren and parents, ${ }^{258}$ fewer estates would qualify for the special valuation rules of $\S 2032 \mathrm{~A}$, resulting in greater incidence of taxation than under current law. ${ }^{259}$

Similar to its impact on the availability of $\$ 2032 \mathrm{~A}$, the narrow definition of family would cause greater incidence of taxation under $\S 6166$. The fewer people whose ownership may be attributed to the taxpayer, the fewer estates will qualify for the extension of time in which to pay taxes. Although $\S 6166$ admittedly would be affected less than $\S 2032 \mathrm{~A}$ (because of $\S 6166$ 's greater definitional similarities to "related" parties under $\S 2036(\mathrm{~b})(2))$, ${ }^{260}$ adopting a narrow definition of family likely would result in a similar increase in the incidence of taxation compared to current law. ${ }^{261}$

From both the government's and taxpayers' perspectives, the universal adoption of the narrow definition of "related" persons made applicable to $\S 2036(a)(1)$ by $\S 2036(b)(2)$ would have mixed benefits. The government would be distressed (and taxpayers pleased) that fewer transactions would be taxed under $\S 2036(\mathrm{a})(2){ }^{262}$ but the government would be pleased (and taxpayers distressed) by fewer estates qualifying for the special valuation rules

254. See supra note 101 and accompanying text.

255. See supra note 27 and accompanying text.

256. See supra notes $68-70$ and accompanying text.

257. See supra notes 63-67 and accompanying text.

258. See supra note 27 and accompanying text.

259. This analysis assumes current levels of taxation as the baseline measure, without normative judgment about the appropriate level of taxation.

260. See infra Appendix. The only difference between the proposed narrow definition of family and $\S 6166$ is that the narrow definition does not include siblings whereas $\$ 6166$ does. LR,C. $\S \S 6166(\mathrm{~b})(2)(\mathrm{D}), 267(\mathrm{c})(4)$. Siblings are not members of the family for purposes of $\S 2036(\mathrm{a})(\mathrm{l})$. Cf. $i d$. $\S \S 2036(\mathrm{a})(1), 2036(\mathrm{~b})(2), 318(\mathrm{a})(1)(\mathrm{A})$.

261. Cf. 1.R.C. $\S \S 6166(\mathrm{~b})(1)(\mathrm{B}),(2)(\mathrm{D})$.

262. See supra Part I.A.2. 
of $\S 2032 \mathrm{~A}^{263}$ and extensions of time to pay estate taxes under $\S 6166^{264}$ For these reasons, implementing a narrow uniform definition of family likely would garner little support from either constituency. Furthermore, a narrow definition of family would not effectuate legislative intent. Congress was concerned about taxpayers who sought to evade estate taxation while retaining control over transferred property, ${ }^{265}$ and a narrow definition of "family" as the spouse, children, grandchildren and parents would create opportunities for the very type of strategic behavior that Congress sought to minimize. Similarly, a narrow definition of family for purposes of $\S \S 2032 \mathrm{~A}$ and 6166 would preclude tax relief for the very types of estates that Congress intended to benefit. ${ }^{266}$ As a policy matter, adoption of a narrow definition would be inconsistent with legislative purpose.

\section{Adopt I.R.C. $\$ 2032 A$ 's Broad Definition}

If adoption of a uniform narrow definition of family would be unpopular or undesirable from a policy perspective, it is instructive to consider the opposite-adopting a broad definition of family. Of all the Code sections, $\S 2032 \mathrm{~A}$ takes the broadest approach ${ }^{267}$ by defining the family as a taxpayer's ancestors, spouse, any lineal descendant of the taxpayer, a lineal descendant of the taxpayer's spouse, any descendant of the taxpayer's parents and the spouse of any lineal descendant of the taxpayer, the taxpayer's spouse or any descendant of the taxpayer's parents. ${ }^{268}$ Not surprisingly, though, universal adoption of this broad definition of family would cause a pattern of both under-taxation and over-taxation.

\section{a. Impact on Estate Tax Inclusion}

Adopting $\S 2032 \mathrm{~A}$ 's broad definition as the uniform estate tax definition of family would cause more transactions to be taxed under $\S 2036$ than are currently. A broad definition also would tax more transactions than are necessary in order to address lawmakers' concerns about taxpayer control over transferred assets. Consider another hypothetical.

263. See supra Part LB.

264. See supra Part I.C.

265. See supra Part II.A.

266. See supra Part I.B, C.

267. See supra Part I.D.

268. See supra notes $73-77$ and accompanying text. 
Hypothetical 11. Assume the same facts as in Hypothetical 1, except that Dora Ewing owns $5 \%$ of Company Y's total outstanding stock. Dora Ewing again transfers to Friend Frank her underlying equity interest in all of her Company $Y$ stock. Dora Ewing retains the right to vote the shares. At the time of Dora Ewing's death, her sister-in-law, Mary Mack, owns $95 \%$ of the Company Y stock.

Under $\S 2036(\mathrm{~b})(2)$ 's existing definition of a controlled corporation, Mary Mack is not a member of Dora Ewing's family, ${ }^{269}$ and so Dora Ewing's five percent ownership is not aggregated for estate tax purposes with Mary Mack's $95 \% .{ }^{270}$ Under current law, the Company $Y$ stock is not included in Dora Ewing's estate. ${ }^{271}$ If $\S 2032 \mathrm{~A}$ 's broad definition of family were adopted, however, Mary Mack would be considered a member of Dora Ewing's family under the new definition. ${ }^{272}$ The constructive ownership rules thus would cause Mrs. Ewing to be the deemed owner of $100 \%$ of Company Y's stock and it would be a controlled corporation with respect to her. ${ }^{273}$ As in Hypothetical 1 , then, the full value of the stock transferred to Friend Frank would be included in Dora Ewing's gross estate under $\S 2036(\mathrm{a})(1){ }^{274}$ This is inappropriate because, in fact, in a small business owned $5 \%$ by a taxpayer and $95 \%$ by her sister-in-law, the shareholders likely will have different economic interests. ${ }^{275}$

Similar to the result under $\S 2036(a)(1)$, adoption of $\S 2032 A$ 's broad definition of family would cause more transfers to be included in a taxpayer's gxoss estate under $\S 2036$ (a)(2) than are presently included. By way of illustration, under current law, a taxpayer's cousin is not "related" to the taxpayer for purposes of $\S 672(\mathrm{c})$ and $\$ 2036(\mathrm{a})(2) .{ }^{276}$ Thus, without adverse tax consequences, a taxpayer can retain the unrestricted right to remove a trustee who has discretionary authority to make distributions from the trust and replace the trustee with his or her cousin, for example. ${ }^{277}$ If a broad

269. I.R.C. $\S 318(a)(1)(A)$ (incorporated by reference into $\S 2036(\mathrm{~b})(2)^{\prime} s$ definition of controlled corporation).

270. See id. $\$ 2036(\mathrm{~b})(2)$.

271. Id. $\$ 2036(\mathrm{a})(1),(\mathrm{b})(2)$.

272. See id. $\$ 2032 \mathrm{~A}(\mathrm{a})(1)(\mathrm{A})$.

273. Id. $\$ 2036(\mathrm{~b})(2)$.

274. Id. $\$ 2036(\mathrm{~b})(1),(2)$.

275. Jensen, supra note 19, at 201 ("[Clonflict among siblings is common."); see also Kenneth Kaye, Penetrating the Cycle of Sustained Conflict, BUS. HoRIzONS, Spring 1991, reprinted in FAMILY BUSENESS SOURCEBOOK II 355, 369-70 (Craig E. Atonoff et al. eds., 1996).

276. See I.R.C. $\$ 672(\mathrm{c})(\mathrm{l})$.

277. See, e.g., Estate of Farrel v. United States, 553 F.2d 637 (Ct. Cl. 1977); cf. Estate of Wall v. Comm'r, 101 T.C. 300 (1993). 
definition of family were adopted, however, a taxpayer's cousin would be defined as "related" to the taxpayer, and any ability to remove and replace with the cousin-trustee would trigger estate tax inclusion under $\S 2036(\mathrm{a})(2){ }^{278}$ The overall impact of the adoption of a broad definition of family would be the inclusion of more transfers in the gross estate than under current law. Although Congress was concerned with the ability of taxpayers to retain control over transferred assets through a trustee who functions, in effect, as the transferor's alter-ego, ${ }^{279}$ Congress did not intend to implement a per se rule against a trustee who is related to the transferor within any degree of consanguinity. Such a broad definition of family is inconsistent with legislative intent.

\section{b. Impact on Estate Tax Payment}

If the $\S 2032 \mathrm{~A}$ definition of family were adopted for all estate tax purposes, more transfers would be included in the gross estate than are currently included, but it also would become easier to qualify for an extension of time to pay estate taxes under $\S 6166$. Consider this variation on Hypothetical 7.

Hypothetical 12. Assume the same facts as in Hypothetical 7, above, except that of the 49 shareholders other than Dora Ewing, one is her stepson, Roger Lucas; one is her stepson's wife, Abby Gale; one is her nephew, John Ewing; one is her sister-in-law, Mary Mack; and one is her daughter-in-law, Gloe Cox. The other 44 shareholders are not related to Dora Ewing in any way.

As in Hypothetical 7, in this hypothetical, the holdings of Dora Ewing alone do not rise to the level that would make Company $\mathrm{Y}$ a closely held corporation with respect to her. ${ }^{280}$ It is closely held, however, if it has 45 or fewer shareholders, ${ }^{281}$ with the taxpayer's holdings being aggregated with the holdings of members of his or her family. ${ }^{282}$ If $\S 2032 \mathrm{~A}$ 's uniform definition applies, then Dora Ewing is deemed to own the shares held by her stepson, Roger Lucas; her stepson's wife, Abby Gale; her nephew, John Ewing; her

278. See supra note 35 .

279. See supra Part II.A.

280. See I.R.C. $\$ 6166(b)(1)(C)(1)$ (decedent's stock ownership of a corporation will be a closely held business interest for purposes of $\S 6166(a)(1)$ if decedent's gross estate includes twenty percent or more of the value of the voting stock of the corporation).

281. Id. \$6166(b)(1)(C)(ii).

282. ld. $\$ 6166(b)(2)(D)$. 
sister-in-law, Mary Mack; and her daughter-in-law, Gloe Cox. Thus Company $Y$ would be deemed to have 45 total shareholders (i.e., Dora Ewing and the 44 individuals who are not "related" to her). Company $Y$ therefore would be a closely held business with respect to Dora Ewing within the meaning of $\S 6166(\mathrm{~b})(\mathrm{l})(\mathrm{C})(\mathrm{ii})^{283}$ and Dora Ewing's estate would be eligible for the deferred payment provisions of $\$ 6166$.

Hypothetical 12 raises the question of whether adoption of a uniform definition of family based on $\$ 2032 \mathrm{~A}$ would make it too easy to qualify for the extension of time to pay estate taxes under $\S 6166$. The extension was developed for those estates that might have liquidity problems because of the unique nature of family-owned businesses. ${ }^{284}$ But the shareholders in Hypothetical 12 are related to each other distantly or by marriage only and perhaps do not need the same amount of time to pay taxes that is needed by the owner of businesses like the ones legislators had in mind when enacting $\S 2032 \mathrm{~A} .^{285}$ A business that is owned by a taxpayer; her stepson, Roger Lucas; her stepson's wife, Abby Gale; her nephew, John Ewing; her sister-inlaw, Mary Mack; her daughter-in-law, Gloe Cox; and 44 unrelated people likely does not have the same characteristics as the classic family farm or small family business. For that reason adopting a broad definition of family would result in taxpayers such as Dora Ewing in Hypothetical 12 receiving an extension of time to pay taxes when they do not need extra time to pay.

\section{B. Eliminate All Family-Based Preferences and Penalties}

Instead of adopting a uniform definition of family for estate tax purposes, another response to the many conflicting estate tax definitions of family would be eliminating all estate tax preferences and penalties that depend on family relationships. ${ }^{286}$ Such elimination is not desirable, however, because it would lead to both abusive behavior by taxpayers seeking to evade taxation and financial hardship for many estates.

To illustrate the consequences of eliminating all estate tax preferences and penalties for families, consider again Hypothetical 2. In that case, Dora Ewing's ownership of Company Y stock causes the full value of the Company

283. See id. $\$ 6166(b)(1)(C)(i i)$.

284. See supra Part I.C.

285. See supra Part II.B.

286. Something similar was suggested in a question by Professor Darlene Kennedy in response to an earlier version of this paper delivered at the Annual Meeting of the Law and Society Association, Las Vegas, Nevada on June 4, 2005. 
$\mathrm{Y}$ stock to be included in her gross estate. ${ }^{287}$ This is because under the constructive ownership rules of $\S 318$, she owns her father's $95 \%$ interest, making Company $\mathrm{Y}$ a controlled corporation with respect to her. ${ }^{288}$ If, however, "family" were made irrelevant for purposes of $\S 2036$ (b)(2), then Dora Ewing's father's stock ownership would not be attributed to her, ${ }^{289}$ Company $Y$ would not be a controlled corporation with respect to her and the value of the transferred shares of Company $Y$ stock would not be included in her gross estate. ${ }^{290}$

A uniformly broad definition of family also creates opportunities for abusive transactions under $\$ 2036$ (a) (2). Under current law, assets transferred by a taxpayer will be included in the taxpayer's gross estate where he or she retains the power to remove a trustee and replace him or her with a person who is related or subordinate to the taxpayer within the meaning of $\S 672(\mathrm{c}){ }^{291}$ If the prohibition on the removal and replacement of "related" trustees were eliminated, however, a taxpayer could appoint, remove and replace as trustee his or her spouse or child, among others, without any negative tax consequences. ${ }^{292}$ Nothing would prevent the taxpayer from treating the trust as a will substitute (or worse, an alter ego), thus eroding the purpose of the estate tax law which aims to include in the taxpayer's gross estate transfers that are testamentary in nature. ${ }^{293}$

If all preferences for families were eliminated in the estate tax law, there would be no special valuation of real estate under $\S 2032,{ }^{294}$ which in turn would cause real property to be valued at higher levels than under current law. ${ }^{295}$ Similarly, with no extensions of time to pay estate taxes under $\S 6166,{ }^{296}$ family-business owners might have to liquidate the business in order to pay in a timely fashion any estate tax owed..$^{297}$ Congressional intent

287. See supra notes $24-25$ and accompanying text.

288. I.R.C. $\$ 2036(\mathrm{~b}) ;$ see supra notes $29-31$ and accompanying text.

289. See I.R.C. $\$ 2036(b)$.

290. See id. \& 2036(a)(1), (b)(2).

291. See id. $\$ 672(c)(1)$.

292. See id. $\$ 2036(a)(2)$.

293. See, e.g., id. $\$ \$ 2035-2038$; see also Willbanks, supra note 18 , at 5 ("Once it decided to retain the federal estate tax, Congress recognized the possibilities of tax avoidance through inter vivos gifts and adopted a gift tax in 1924.").

294. See supra Part 1 B.

295. See supra note 58.

296. See supra Part LC.

297. See I.R.C. $\S 6075$ (a) (due date for payment of estate taxes ordinarily is nine months after decedent's death); see also supra note 105 . 
to "solve the handicaps of new and small businesses" would be thwarted" if farmers and small business owners had fewer estate tax benefits.

\section{Eliminate the Family-Based Preferences}

As an alternative to eliminating all family-based preferences and penalties, it may be appropriate to consider eliminating only the preferential rules, in light of the purposes of $\$ \S 2036,2032 \mathrm{~A}$ and 6166 and contemporary experiences of the family. Of the three Code sections, $\$ 2036$ is unique in its concern about taxpayers who seek to evade estate taxation through 'transfers of assets over which they (or their surrogates) maintain control. ${ }^{299}$ Section 2036 uses concepts of family and "related" taxpayers in order to facilitate efficient application of the law. Otherwise, there would need to be a case-bycase inquiry into every transfer of property over which the decedent retains voting rights or unrestricted rights to remove or replace a trustee. The definitions of "controlled corporation"300 and "related or subordinate"301 supply predictable bright line tests that allow taxpayers to determine ex ante what arrangements will trigger estate tax inclusion under $\S 2036$.

In contrast to $\S 2036$ 's concern with control, both $\S 2032 \mathrm{~A}$ and $\S 6166$ bestow benefits on certain taxpayers-small business owners-who are engaged in business activities that Congress has labeled as more worthy. ${ }^{302}$ Given the purposes of each of $\S \S 2032 \mathrm{~A}$ and 6166 , however, it is perhaps inappropriate to limit the estate tax benefits to family transfers (in the case of $\S 2032 \mathrm{~A})^{303}$ or apply favorable rules to families that do not apply to unrelated taxpayers (in the case of $\S 6166^{\prime}$ 's methodology for determining the number of owners of a business). ${ }^{304}$ After all, the estate of a small business owner faces the same liquidity concerns regardless of whether the decedent transfers real property used in the business to a family member (and "qualified heir") ) $^{305}$ or to a long-term (but unrelated) business partner. Similarly a business owned by a group of, say, 50 unrelated taxpayers may function in fact more like a closely-held business than one owned by a taxpayer, his or her six children

298. See supra note 171 and accompanying text.

299. See supra Part II.A.

300. See supra note 23 and acconpanying text.

301. See supra notes $37-43$ and accompanying text.

302. See supra Part I. B-C.

303. See supra notes $69-77$ and accompanying text.

304. See supra note 113 and accompanying text.

305. See supra notes $69-77$ and accompanying text. 
and 44 grandchildren, although the latter would qualify as a closely-held business under current law and the former would not. ${ }^{306}$

Section 2032A's and $\S 6166$ 's reliance on family-based tests seems especially inappropriate given the changing nature of the American family. ${ }^{307}$ The definitions of family are under-inclusive and, as Hypothetical 9 illustrates, otherwise qualifying estates may be ineligible for benefits solely because of a lack of formalized marital relationship between taxpayers; for example. Lawmakers could consider two possible solutions to this problem: either adopt a case-by-case analysis that could accommodate nontraditional family arrangements or eliminate the family-based benefits under $\S \S 2032 \mathrm{~A}$ and 6166 . The first of these alternatives, a case-by-case analysis, would be cumbersome and unpredictable. Taxpayers would be unable to forecast with certainty whether a particular relationship would be determined to be sufficiently "family-like" to make certain transfers eligible for favorable treatment under $\S 2032 \mathrm{~A}$ or $\S 6166$. The second alternative, eliminating the family-based benefits under these Code sections, would be politically unfeasible, given the importance of the small business owner and family farmer in congressional thetoric. ${ }^{308}$ Taxpayers would hardly welcome elimination of the special valuation rules and extension of time to pay taxes.

\section{Increase the Estate Tax Exemption}

As an alternative to estate tax repeal, congressional leaders are discussing the possibility of increasing the estate tax exemption to an amount from $\$ 1.5$ million to between $\$ 8$ million and $\$ 10$ million per taxpayer. ${ }^{309}$ If the

306. See supra Part LC.2.

307. See supra Part IILB.

308. See supra Part II.B-C.

309. Brody Mullins, Senators Discuss Compromise Bill For the Estate Tax, WALL ST. J., Apr. 8, 2005, at B2. Such an approach is similar to the system proposed in Crawford, supra note 56. Professor Michael Graetz of Yale Law School has proposed a per-person estate tax exemption of $\$ 5$ million, or $\$ 10$ million for married couples. See David Cay Johnston, Few Wealthy Farmers Owe Estate Taxes, Report Says, N.Y. Times, July 10, 2005, at A21 (describing views of Professor Graetz). For commentary on the econornic implications of the proposal to raise the exemption to $\$ 8$ million per person, see Joel Friedman \& Ruth Carlitz, Kyl Estate Tax "Compromise" Proposal Extremely Costly (2005), http://www.cbpp.org/77-05tax/pdf; see also Dustin Stamper, Baucus, Kyl Agree on Estate Tax 'Parameters,' 108 TAx NoTEs 263, 263 (2005) (describing agreement between Senator John Kyl, R-Ariz., and Senator Max Baucus, DuMont., to design estate tax reform bill that retains extension of time to pay estate taxes, inter alia, while raising exemption amount and lowering maximum tax rate). A recent version of the proposal includes a $\$ 3.5$ million exemption and a top estate tax rate of fifteen percent. Editorial, The State of the Estate Tax, N.Y. TIMES, Aug. 8, 2005, at A14. A New York Times editorial criticizes a $\$ 3.5$ million exemption as "overly generous," and suggests that "a $\$ 2$ million exemption would be ample to protect the hard-working families, 
exemption were so increased, far fewer taxpayers would be forced to navigate the complex and conflicting estate tax definitions of family. By way of illustration, in 2002, 98,359 estate tax returns were filed, but only $1.9 \%$ of those were for gross estates valued at $\$ 10$ million or more. ${ }^{310}$ of that $1.9 \%$, a full one-third of the returns were for nontaxable estates. ${ }^{311}$ The other twothirds contributed more than $36 \%$ of the total estate tax revenue for $2002 .^{312}$ Presumably estates of the relatively few ultra-wealthy taxpayers can afford sophisticated tax advice and interpreting the conflicting estate tax definitions of family is not a significant burden. ${ }^{313}$

Even though fewer estates would be subject to the complexities of the estate tax if the exemption were raised to $\$ 10$ million, three important concerns would remain. First, the concept of horizontal equity in taxation demands that "similarly situated individuals should be taxed similarly." 114 If the tax law is too complicated, only those who seek (and receive) quality tax advice will have lower tax bills. ${ }^{315}$ Insofar as all taxpayers have the equal opportunity to seek advice, there is no violation of the principle of horizontal equity. But the only people who benefit from such a system are the advicegiving lawyers and accountants-not taxpayers. Second, the cost of complying with and enforcing the law would remain extremely high. ${ }^{316}$ In

entrepreneurs and farmers that estate tax foes claim to care about most." Id. The New York Times editorial also supports a higher top rate, explaining that a higher rate would "keep the tax fair" whereas "a fifteen percent tax rate would transhate to a mere six percent levy on a $\$ 20$ million estate" Id.

310. Statistics of Income Division, Internal Revenue Serv, Estate Tax Returns Filed in 2002 (2004), http://www,irs.gow/taxstats/indtaxstats/article $/ 0$, id $=96442,00$,html.

311. The rest likely qualified for the charitable or marital deduction. See id.

312. See id.

313. For a general example of the sophisticated level of legal advice that a wealthy decedent's estate can afford, see Jonathan G. Blattmachr, The Complete Guide to Wealth Preservation and Estate Planinng (2000).

314. Willbanks, supra note 18 , at 9 . On the role of horizontal equity in taxation generally, see Michael A. Livingston, TAXation Law, Planning \& Policy, at Xxv-xxxvi (2003); see also Christopher T. Nixon, Should Congress Revise the Tax Code to Extend the Same Tax Benefits to Same-Sex Couples as Are Currently Granted to Married Couples? An Analysis in Light of Horizontal Equity, 23 S. ILL. U. L.J. 41 (1998) (comparing tax treatment of same-sex couples and opposite-sex married couples).

315. See James R. Repetti, Democracy, Taxes, and Wealth, 76 N.Y.U. L. REV. 825, 868-69 (2001) (complex Code provisions "create an equity problem because they provide the greatest benefit to those who seek sophisticated tax advice. To the extent that the estate tax does impose an unacceptable burden, policymakers need to identify the benefits provided by small businesses and family farms and to determine the best way to target tax relief to those companies providing the benefits:").

316. Professor Stephanie Willbanks articulatesan important goal of any tax system as "administrative feasibility," explaining that "[i]t should not impose significant costs for enforcement, compliance or planning. Other principles include: simplicity, stability, and directness, i.e., how visible is the tax to those who pay it?' Willbanks, supra note 18 , at 10 . 
fact, the cost could even increase, if auditing more large estates required greater commitment of governmental resources. Finally, the loss of estate tax revenue would be significant. ${ }^{317}$ Raising the estate tax exemption, therefore, may be a partial solution, but it is incomplete in at least three important ways.

\section{E. Revise Terminology to Achieve Statutory Integrity}

\section{Generally}

Each of the proposals considered so far in this Part-adopting a uniform definition of family, eliminating all preferences and penalties for families, eliminating only the family-based preferences, and raising the estate tax exemption - has significant flaws. No single definition of family discussed here would effectuate legislative intent, ${ }^{318}$ and it is unlikely that any single definition would be appropriate for all estate tax purposes, given the diverse purposes for which the laws were enacted. Eliminating all family-based estate tax rules likely would result in systematic over-taxation or under-taxation, using legislative intent and existing levels of taxation as a reference. One variation on this proposal, eliminating only the beneficial provisions of $\S \S 2032 \mathrm{~A}$ and 6166 , would be politically unpopular, if not impossible to implement. The option of raising the estate tax exemption would minimize the number of taxpayers who would be subject to the conflicting meanings of family in estate tax law, but such an increase would not eliminate the law's complexity.

In light of these unsatisfactory options, the best (and perhaps the simplest) solution is revising the statutes to eliminate internal conflict over terms like "family" and "related" persons and to reflect each Code section's unique purposes. Within a body of law, words should be used consistently and, to the extent possible, in ways that comport with lay understanding. ${ }^{319}$ Statutory integrity is a fundamental requirement for public confidence in the legal system. As Ronald Dworkin observes,

317. See Friedman \& Carlitz, supra note 309. Over the ten year period, from 2012 to 2021 , the Center on Budget and Policy Priorities estimates that raising the estate tax exemption to $\$ 8$ million per person would cost up to $\$ 700$ million in lost revenue. Id.

318. See supra Pants I, IV.A.

319. See supra note 7. Although this subpart outlines some of the most significant changes that would need to be made in connection with the proposal to achieve statutory integrity, a comprehensive legislative proposal is beyond the scope of this Article. 
Internally compromised statutes cannot be seen as flowing from any single coherent scheme of principle; on the contrary, they serve the incompatible aim of a rulebook community, which is to compromise convictions along lines of power. They contradict rather than confirm the commitment necessary to make a large and diverse political society a genuine rather than a bare community: the promise that law will be chosen, changed, developed, and interpreted in an overall principled way. ${ }^{320}$

If it is not possible to use terms like "family" and "related" persons consistently across Code sections, then it is appropriate to consider using distinct terms for their unique and limited purposes. The proposed terms also would more closely effectuate legislative intent.

\section{Revisions to I.R.C. $\$ 2036$}

In the case of $\S 2036(\mathrm{a})(1)$, its estate tax inclusion rule does not contain any reference to "family" and would not need to be revised. Instead the revisions would need be made to the definition of "controlled corporation" of $\S 2036(\mathrm{~b})(2)$ that is made applicable to $\S 2036(\mathrm{a})(1)$. The definition of "controlled corporation" could be revised to use a self-contained attribution rule, instead of incorporating the attribution rule of $\S 318$ by reference. The self-contained attribution rule could refer to members of the "Attribution Group" instead of members of the decedent's "family." "32! That way, it would

320. RONALD DWORKIN, LAW'S EMPIRE 214 (1986). Although statutory integrity as used here refers to consistency in language and interpretation, William Eskridge and Philip Frickey emphasize Dworkin's interest in moral consistency. Williarn N. Eskridge, Jr. \& Philip P. Frickey, Legislation Scholarship and Pedagogy in the Postwegal Process Era, 48 U. PiTT. L. REV. 691, 721-22 (1987). They claim that Dworkin would "require[] lawmakers to try to make the total set of laws morally coherent. . . . The courts' role is to interpret authoritative statements of law (the Constitution, statutes, common law precedents) in light of the underlying principles of the community. Thus, in the 'hard cases' of statutory interpretation, the best interpretation is the one that is most consonant with the underlying values of society and makes the statute the best statute it can be (within the limitations imposed by the language)." Id. (citations omitted).

321. A newly-revised $\$ 2036(\mathrm{~b})(2)$ might read as follows:

(2) Controlled comporation. For purposes of paragraph (1), a corporation shall be treated as a controlled corporation if, at any time after the transfer of the property and during the three-year period ending on the date of the decedent's death; the decedent owned (with the application of paragraph (3)), or had the right (either alone or in conjunction with any other person) to vote, stock possersing at least twenty percent of the total combined voting power of all classes of stock.

(3) Attribution. An individual shall be considered as owning the stock owned, directly or indirectly, by or for any member of the Atribution Group. The Attribution Group shall consist of the individual's spouse (other than a spouse who is legally separated from the individual under a decree of divorce or separate maintenance), and the individual's children, grandchildren, and parents.

Further sections would need to be added to provide for attribution to and from partnerships, estates, trusts, and corporations, as well as the treatment of stock options as stock ownership for limited purposes of the 
be plain that the language of $\S 2036(b)(2)$ should not be read and was not intended to harmonize with any other Code section.

Similarly, with respect to inclusion under $\$ 2036$ (a)(2), that section would not need to be revised. Instead, the Service should withdraw Revenue Ruling 95-58, ${ }^{322}$ applicable to the interpretation of $\S 2036(\mathrm{a})(2)$, and issue a new ruling that prohibits removal of a trustee and replacement by a person who is a member of the "Prohibited Class," for example, instead of a person who is "related or subordinate."323 Alternately the Service could withdraw Revenue Ruling 95-58 and add an example to the regulations under $\S 2036$, making clear that a transferor-decedent risks estate tax inclusion where he or she retains the right to remove a trustee and replace him or her with a member of the Prohibited Class. ${ }^{324}$

As part of the statutory change of terms to "Attribution Group" and "Prohibited Class," those terms could be drafted to include any person who is defined for purposes of local law as a registered domestic partner or "spouse" of the taxpayer. ${ }^{325}$ This would allow the estate tax inclusion rule to reach transfers in the context of family-like relationships that presently are not recognized as "family" for federal tax purposes. Including domestic partners and state-law spouses within the $\S 2036$ definition would be consistent with the legislature's concern over taxpayer control. ${ }^{326}$ Furthermore, insofar as the revised $\S 2036$ would apply only to domestic partnerships and marriages that are recognized by the state, there should be little, if any, evidentiary concern over who is a registered domestic partner or spouse for state law purposes.

new $\$ 2036($ b)(3). See I.R.C. $\$ 318(a)$ (4) (person with option to acquire stock is treated as owning that stock). The current $\$ 2036($ b) (3) (entitled "coordination with section 2035 ") would need to be renumbered.

322. Rev. Rul. 95-58, 1995-2 C.B. 191.

323. The Prohibited Class could be defined as the taxpayer's spouse, father, mother, issue, brother or sister; any employee of the taxpayer; any corporation or employee of a corporation in which the holdings of a taxpayer (or the particular trust in question) "are significant from the viewpoint of voting contro"; and "subordinate" employees of a corporation in which the taxpayer is an executive. See supra notes 39-43.

324. To Treasury Regulation $\$ 20.2036-\mathrm{I}(\mathrm{b})$, for example, there could be added the following new paragraph: "(4) The phrase right ... to designate the person or persons who shall possess or enjoy the trans ferred property or the income therefrom' includes a reserved right to remove and replace a trustee who is a member of the Prohibited Class." The "Prohibited Class" would then be defined as in supra note 323 .

325 . If the terms were drafted broadly, the second sentence of the new $\$ 2036(\mathrm{~b})$ (3) would provide that the Attribution Group "shall consist of the individual's spouse (other than a spouse who is legally separated from the individual under a decree of divorce or separate maintenance), any person who is registered as a domestic partner under the state or local laws of the taxpayer's domicile, any person who is defined as the taxpayer's spouse for purposes of state law, and the individual's children, grandchildren, and parents." The definition of Prohibited Class would be expanded similarly.

326. See supra Part M.A. 


\section{Revisions to I.R.C. $\$ 2032 A$}

Because it relies heavily on "family" as a defined term to implement its substantive rule, $\$ 2032 \mathrm{~A}$ would need more extensive revisions to achieve the desired statutory integrity. Apart from the purely semantic change of replacing "family" with a term such as "Qualified Heir Group," it would be appropriate to consider expanding the definition's substance in light of $\$ 2032 \mathrm{~A}$ 's underlying policy goal of providing tax relief to the family farmer or small business owner. ${ }^{327}$ The "Qualified Heir Group" could be defined as all of the persons who are included under existing law as members of a taxpayer's "family"328 as well as any other individual whose total real estate and farm holdings are below a certain fair market value. That would allow a decedent to leave real property to a long-time employee who, for example, spends 30 years working on the farm before the decedent's death, without extending the special valuation rule in cases where a decedent's family decides to sell the family farm to a large agribusiness conglomerate. As a matter of practical politics, it is extremely unlikely that Congress would expand the definition of "Qualified Heir Group" to include persons who are registered as domestic partners or recognized as spouses for state law purposes. From a policy perspective, however, renaming and expanding the definition of a "qualified heir" to include domestic partners (as well as their descendants) is consistent with the statute's desire to foster small farms and business activities. There is no logical reason that the tax benefits should be limited to transfers to relations by blood or federally-recognized marriage. ${ }^{329}$

327. See supra Part II.B.

328. For purposes of the current $\$ 2032 \mathrm{~A}$, a taxpayer-decedent's "fanily" consists of (A) any of the taxpayer's ancestors; (B) the taxpayer's spouse; (C) any lineal descendant of the taxpayer; (D) a lineal descendant of the taxpayer's spouse; (E) any descendant of the taxpayer's parents (1.e, a taxpayer's siblings, nieces and nephews, etc.); and (F) any spouse of any lineal descendant of the taxpayer, the taxpayer's spouse or any descendant of the taxpayer's parents. See supra notes 72-77 and accompanying text.

329. The term "Qualified Heir Group" would apply for purposes of the fifty percent and twenty-five percent threshold tests. See I.R.C. $\$ \S 2032 \mathrm{~A}(\mathrm{~b})(1)(\mathrm{B})$ (fifty percent test), 2032A(b)(I)(C) (twenty-five percent test). For example, $\$ 2032 \mathrm{~A}(\mathrm{~b})(1)$ could be revised as follows:

(b) Qualified real property.m.

(1) In general--For purposes of this section, the term "qualified real property" means real property located in the United States which was acquired from or passed from the decedent to a member of the Qualified Heir Group and which, on the date of the decedent's death, was being used for a qualified use by the decedent or a member of the Qualified Heir Group, but only if -

(A) fifty percent or more of the adjusted value of the decedent's gross estate consists of the adjusted value of real or personal property which-

(i) on the date of the decedent's death, was being used for a qualified use by the 


\section{Revisions to I.R.C. $\S 6166$}

As with $\S 2032 \mathrm{~A}$, the substantive meaning of $\S 6166$ derives in substantial part from its definition of family, and so revising the definition entails significant changes to the statute. As with $\S 2036$, the definition of family is incorporated by reference to a separate Code section, ${ }^{330}$ and so achieving the desired statutory integrity will require rewriting $\S 6166$ to have a self-contained attribution rule. In particular, $\$ 6166$ might be rewritten to attribute to a taxpayer the holdings of his or her "Closely Held Business Associates" instead of his or her "family" as defined in $\$ 267(\mathrm{c})(4){ }^{331}$ The Closely Held Business Associates could include all persons defined under the current $\S 6166$ as a "member" of a decedent's "family."332 The term would be applicable only for the limited purposes of $\S 6166$ and would not bear any resemblance to terminology used in any other Code section. Again, though, to the extent that Congress is concerned about the longevity of small businesses, it may be theoretically appropriate, if politically unfeasible, to include registered domestic partners and state-law spouses within that group.

decedent or a member of the Qualified Heir Group, and

(ii) was acquired from or passes from the decedent to a member of the Qualified Heir Group.

(B) twenty-five percent or more of the adjusted value of the gross estate consists of the adjusted value of real property which meets the requirements of subparagraphs (A)(ii) and (C),

(C) during the eight-year period ending on the date of the decedent's death there have been periods aggregating five years or more during which--

(i) such real property was owned by the decedent or a member of the Qualified Heir Group and used for a qualified use by the decedent or a member of the Qualified Heir Group, and

(ii) there was material participation by the decedent or a member of the Qualified Heir

Group in the operation of the farm or other business, and

(D) such real property is designated in the agreement referred to in subsection (d)(2).

330. See supra note 125 and accompanying text.

331. See supra note 125 and accompanying text.

332. For purposes of the current $\$ 6166$, the taxpayer's "family" is defined byreference to $\$ 267(\mathrm{c})(4)$ as the taxpayer's siblings, spouse, ancestors, and lineal descendants. See supra notes 125-27 and accompanying text. A revised $\$ 6166$ (b)(2)(D) might read in pertinent part as follows:

(D) Certain interests held by others. All stock and all partnership interests held by the decedent or by any member of the Closely Held Business Associates shall be treated as owned by the decedent.

(E) Closely Held Business Associates. The Closely Held Business Associates with respect to any individual shall include that individual's brothers and sisters (whether by the whole or half blood), spouse, ancestors, and lineal descendants. 
Ultimately the estate tax law's account of "family" will need to be broadened to include a greater range of the relationships that people call by that name.

\section{CONCLUSION}

Family is both a burden and a benefit for estate tax purposes. Family is a burden to the extent that attribution rules trigger estate tax inclusion under $\S 2036(\mathrm{a})(1),{ }^{333}$ or if the ability to replace a removed trustee with a relative runs afoul of the prohibition on the removal of related or subordinate parties under $\S 2036(\mathrm{a})(2){ }^{334}$ Family is a benefit insofar as it may cause special valuation rules to be available under $\S 2032 \mathrm{~A}^{335}$ or for an estate to have more time to pay taxes under $\S 6166^{336}$ Each of these already intricate Code sections is complicated by a unique definition of "family" or "related" persons. The definitions range from $\S 2036$ (b)(2)'s narrow classification of spouse, children, parents and grandparents as "related" for purposes of $\S \S 2036(\mathrm{~b})(2)$ and $2036(\mathrm{a})(1),{ }^{337}$ to $\S 2032 \mathrm{~A}$ 's broad grouping of ancestors, descendants, step-children, siblings and spouses as members of the same "family." $\$ 338$

The variety in the estate tax definitions of family reflects, to some extent, the diversity in the composition of contemporary American families. In a society in which two-career couples, divorce, remarriage and multigenerational families are common, ${ }^{339}$ laws that seek to tax the transfer of wealth necessarily will have a certain level of complexity. Recent family law scholarship, with its emphasis on connectedness and interdependency, provides a useful lens for examining the strengths and shortcomings of the existing tax rules. ${ }^{340}$ But insofar as family law theorists criticize the relatively low value accorded to women's caretaking activities, those theorists should have little quarrel with the estate tax laws which do not tax the fruits of those caretaking activities.

In response to the complexity of the estate tax rules, a uniform definition of family could be adopted. The main problem with a single definition, however, is the systematic over-taxation or under-taxation that likely would

333. See supra Part LA.1.

334. See supra Part 1.A.2.

335. See supra Part LB.

336. See supra Part I.C.

337. See supra note 27 and accompanying text.

338. See supra notes 73-77 and accompanying text.

339. See supra notes $187-91$ and accompanying text.

340. See supra Part III. 
result $^{341}$ Although only two specific uniform definitions are discussed in detail in this Article, it is unlikely that any uniform definition would be appropriate, given the diverse purposes for which $\$ \S 2036,2032 \mathrm{~A}$ and 6166 were enacted. The second proposal, the elimination of all family-based preferences and penalties, is similarly inadequate. Such a change would lead to abusive behavior by taxpayers or financial hardship for many estates. The third proposal, eliminating only the family-based preferences, may be more appropriate in light of the purposes for which the Code sections were enacted, but this would be politically unpopular, and perhaps impracticable. ${ }^{342}$ The fourth proposal, doing nothing in response to the conflicting meanings of family, is a partial (if incomplete) solution. With the scheduled increases in the estate tax exemption ${ }^{343}$ and perhaps even greater increases to come, ${ }^{344}$ inconsistencies in the estate tax definitions of terms like "family" and "related" may become less inportant if they will apply to fewer estates. ${ }^{345}$ For the few estates to which the law would still apply, it is true that there exists a developed jurisprudence on what constitutes a controlled corporation, ${ }^{346}$ who is "related" to a taxpayer in a tax sense, ${ }^{347}$ when an estate is eligible for the special valuation of real estate ${ }^{348}$ and under what circumstances an estate may receive extra time to pay its tax bill. ${ }^{349}$ Tax lawyers and other advisors are generally familiar with these rules and can, with careful study, advise clients on how to structure their affairs to minimize estate taxes. ${ }^{350}$

341. See supra Part IV.A.

342. See supra Part II.

343. See supra note 167.

344. See supra Part IV,D.

345. According to recent Congressional Budget Office estimates, had the current $\$ 1.5$ million estate tax exemption been in effect in 2000 , fewer than one percent of all estates (approximately 13,770 ) would have been subject to any estate tax. Edmund L. Andrews, Death Tax? Double Tax? For Most, It's No Tax, N.Y. TIMEs, Aug. 14, 2005, at B4.

346. See, e.g., 1 BORIS I. BITTKER \& JAMES S. EusticE, FEDERAL INCOME TAXation OF CORPORATIONS AND SHAREHOLDERS $\$ 9.02$ (7th ed. 2000); Ringel, supra note 207, 211-12; STEPHENS ET AL, supra note $20,14.08[6][\mathrm{d}]$.

347. See, e.g., 9 JACOB MERTEN LAW OF FEDERAL INCOME TAXATION \$ 37:36 (Shane A. Hart ed, 2005) ("Grantor Taxable Because of Power to Control Beneficial Enjoyment"); 47A C.J.S. Internal Revenue $\$ 455$ (2005).

348. See, e.g., Brockman v. Comm's, 903 F.2d 518, 521 (7th Cir. 1990) (definition of "qualified use"); Heffley v. Comm't, 884 F.2d 279, 283-84 (7th Cir. 1989) (same); Bruck v. United States, 86 U.S.T.C. \13,692 (N.D. Ind. 1986) (same); Estate of Abell v. Comm'r, 83 T.C. 696, 699 (1984) (same); Estate of Holmes v. Comm'r, 62 T.C.M. (CCH) 839 (1991) (definition of farming); see also Schuneman v. United States, 783 F.2d 694, 698 (7th Cir. 1986) (definition of "qualified use"); STEPHENS ET AL., supra note $20,14.04$.

349. See, e.g., STEPHENS ET AL., supra note 20, 12.02 [3][c].

350. As Learned Hand famously remarked, "there is nothing sinister in so arranging one's affairs as 
Yet in light of the significant conflict in the estate tax definitions of family, doing nothing is an unacceptable solution. Unless the statutes are revised to achieve some degree of integrity, they will continue to contribute to the general public's sense that the tax laws are unfair and overly complex $^{351}$ This Article proposes using terms like Attribution Group, Qualified Heir Group and Closely Held Business Associates instead of terms like "family" and "related" persons. Although the changes are semantic in some sense, they embody the larger belief that statutes ought to use words consistently and in ways that comport with lay understanding. This will also align the definitions more closely with legislative intent. The rigorous demands of statutory integrity require nothing less.

\footnotetext{
to keep taxes as low as possible ... for nobody owes any public duty to pay more than the law demands." Comm'r v. Newman, 159 F.2d. 848, 850-851 (1947) (Hand, C.J., dissenting). Advocates of maintaining the status quo in the tax laws may point to the predictability in the tax laws as an important policy goal. See Oklahoma Tax Comm'n v. Chickasaw Nation, 515 U.S. 450, 459 (1995) ("[T]ax administration requires predictability."); see also William M. Gentry \& Helen F. Ladd, State Tax Structure and Multiple Policy Objectives, 47 NAT'L TAX J. 747, 747 (1994) (predictability is important in tax policy). Clarity and statutory integrity would seem to be more pressing policy goals in this case, however.

351. McLaughlin \& Assoc., Voters 2 to 1 Say Estate Tax is "Unfair"-Even For Billionaires (2001), http:/www.mclaughlinonline.com/newspoll/np2001/010525est.htm.
} 


\section{APpendix}

\section{Who Is a Member of the Family for Estate Tax Purposes? ?52 $^{32}$}

\begin{tabular}{|c|c|c|c|c|}
\hline $\begin{array}{l}\text { Tndividual or Ciass of } \\
\text { individuals }\end{array}$ & 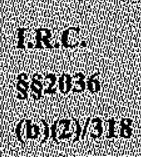 & 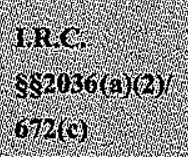 & inc & 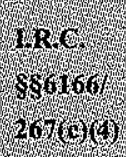 \\
\hline The transferor's spouse & $\operatorname{Yes}^{353}$ & $\mathrm{Yes}^{354}$ & Yes & Yes \\
\hline $\begin{array}{l}\text { Any lineal descendant of the } \\
\text { transferor }\end{array}$ & $\operatorname{Yes}^{35 s}$ & Yes & Yés & Yes \\
\hline $\begin{array}{l}\text { Any lineal descendant of the } \\
\text { transferor's spouse }\end{array}$ & No & No & Yes & No \\
\hline $\begin{array}{l}\text { Any spouse of any lineal } \\
\text { descendant of the transferor }\end{array}$ & No & No & Yes & No \\
\hline $\begin{array}{l}\text { Any spouse of any lineal } \\
\text { descendant of the } \\
\text { transferor's spouse }\end{array}$ & No & No & Yes & No \\
\hline $\begin{array}{l}\text { Any ancestor of the } \\
\text { transferor }\end{array}$ & $\mathrm{Yes}^{356}$ & $\mathrm{Yes}^{357}$ & Yes & Yes \\
\hline
\end{tabular}

352. This chart does not include four categories of persons who potentially are "related or subordinate" parties for purposes of $\$ 2036(a)(2)$ but who are not otherwise considered "related" or members of the "family" for purposes of the other Code sections. Those categories are (a) an employee of the grantor/transferor; (b) a corporation in which the holdings of the grantor and the trust are significant from the viewpoint of voting control; (c) an employee of a corporation in which the holdings of the grantor and the trust are significant from the viewpoint of voting control; and (d) a subordinate employee of a corporation in which the grantor is an executive. L.R.C. $\$ 2036(\mathrm{a})(2), 672$ (c).

353. The spouse is a member of the defined class uniess the spouse is legally separated from the individual under a decree of divorce or separate maintenance. $I d$. $\S \S 2036(\mathrm{~b})(2), 318(\mathrm{a})(1)(\mathrm{A})(\mathrm{i})$.

354. To be a member of the defined class, the transferor's spouse must be living with the grantor. Id. $\$ \S 2036(\mathrm{a})(2), 672(\mathrm{c})$.

355. A lineal descendant is a member of the defined class if he or she is a child or grandchild of the transferor. $1 d . \$ \$ 2036(\mathrm{~b})(2), 318(\mathrm{a})(1)(\mathrm{A})(\mathrm{ii})$.

356. An ancestor is a member of the defined class, if the ancestor is the mother or father of the transferor. Id. $\$ \S 2036(\mathrm{~b})(2), 318(\mathrm{a})(1)$ (A)(ii).

357. An ancestor is a member of the defined class, if the ancestor is the transferor's mother or father. Id. $\$ \S 2036(\mathrm{a})(2), 672(\mathrm{c})$. 


\begin{tabular}{|c|c|c|c|c|}
\hline $\begin{array}{l}\text { Individual or class of } \\
\text { Individuals }\end{array}$ & $\begin{array}{l}\text { liRe. } \\
\text { ss2036 } \\
(6)(29) 318\end{array}$ & 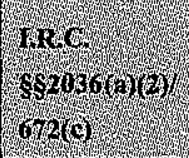 & sine & 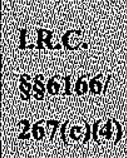 \\
\hline $\begin{array}{l}\text { Any ancestor of the } \\
\text { transferor's spouse }\end{array}$ & No & No & No & No \\
\hline $\begin{array}{l}\text { The spouse of any ancestor } \\
\text { of the transferor }\end{array}$ & No & $\mathrm{No}^{358}$ & No & No \\
\hline $\begin{array}{l}\text { The spouse of any ancestor } \\
\text { of the transferor's spouse }\end{array}$ & No & No & No & No \\
\hline $\begin{array}{l}\text { Any brother or sister of the } \\
\text { individual }\end{array}$ & No & Yes & Yes & Yes \\
\hline $\begin{array}{l}\text { Any spouse of any brother } \\
\text { or sister of the individual }\end{array}$ & No & No & Yes & No \\
\hline $\begin{array}{l}\text { Any descendant of an } \\
\text { individual's sibling (nieces, } \\
\text { nephews, etc.) }\end{array}$ & No & No & Yes & No \\
\hline
\end{tabular}

358. The spouse of an ancestor of the transferor is not a member of the defined class, uniess that spouse is the transferor's own mother or father. Id. $\$ \S 2036(\mathrm{a})(2), 672(\mathrm{c})$. 